\begin{abstract}
UNIVERSIDADE DE SÃO PAULO
FACULDADE DE ECONOMIA, ADMINISTRAÇÃO E CONTABILIDADE DEPARTAMENTO DE ADMINISTRAÇÃO PROGRAMA DE PÓS-GRADUAÇÃO EM ADMINISTRAÇÃO
\end{abstract}

PRISCILA PFAFFMANN DINIZ MORETI

Os estudos do futuro e a sua relação com o processo de inovação nas organizações

SÃO PAULO 
Prof. Dr. Vahan Agopyan

Reitor da Universidade de São Paulo

Prof. Dr. Adalberto Américo Fishmann

Diretor da Faculdade de Economia, Administração e Contabilidade

Prof. Dr. Moacir de Miranda Oliveira Júnior

Chefe do Departamento de Administração

Prof. Dr. Moacir de Miranda Oliveira Júnior

Coordenador do Programa de Pós-graduação em Administração 


\title{
Os estudos do futuro e a sua relação com o processo de inovação nas organizações
}

\author{
Versão Corrigida
}

Dissertação apresentada à Faculdade de Economia, Administração e Contabilidade da Universidade de São Paulo para a obtenção do título de Mestre em Ciências.

Área de Concentração: Administração.

Orientadora: Profa. Dra. Renata Giovinazzo Spers 


\section{FICHA CATALOGRÁFICA}

Elaborada por Rafael Mielli Rodrigues - CRB-8/7286

Seção de Processamento Técnico do SBD/FEA/USP

Moreti, Priscila Pfaffmann Diniz

Os estudos do futuro e sua relação com o processo de inovação nas organizações / Priscila Pfaffmann Diniz Moreti - São Paulo, 2018.

$132 \mathrm{p}$.

Dissertação (Mestrado) - Universidade de São Paulo, 2018.

Orientador: Renata Giovinazzo Spers.

1. Inovação 2. Corporate foresight 3. Processo de inovação 4. Futuro 5. Métodos prospectivos I. Universidade de São Paulo. Faculdade de Economia, Administração e Contabilidade. II. Título.

CDD -658.4 


\section{DEDICATÓRIA}

Dedico esta obra aos meus pais, Patricia Pfaffmann Diniz Moreti e Carlos Eduardo Moreti, ao meu irmão, Thiago Pfaffmann Diniz Moreti, por terem me dado todo amor e suporte para conseguir realizar o meu sonho. E a minha professora, Renata Spers, por ter aceitado encarar esse desafio comigo e sempre ter sido solícita na construção desse trabalho. 



\section{AGRADECIMENTOS}

Eu agradeço primeiramente à Deus que me deu forças para enxergar que eu era capaz de fazer tudo o que eu fiz e acima de tudo me permitiu ter a sensibilidade de ver o amor nas pequenas coisas.

À minha orientadora professora Dra. Renata Spers por ter acreditado no meu potencial, aceitado ser a minha orientadora e ter me ajudado com toda atenção e carinho a realizar o meu sonho, obrigada por toda a sabedoria que a senhora compartilhou comigo.

Ao professor Dr. Paulo Feldman e em memória do professor Dr. James Wright pelas ricas contribuições recebidas no momento da qualificação do meu trabalho.

À equipe do Programa de Estudos do Futuro (Profuturo) da Fundação Instituto Administração (FIA) pelo suporte prestado no momento de coleta de dados. Agradeço especialmente ao professor Dr. Nelson Yoshida, pelo compartilhamento de conhecimentos e experiências durante o meu mestrado e à Ana Paula Oliveira, assistente do MBA Executivo Internacional da FIA, por ter sido solícita na obtenção da amostra de respondentes da pesquisa.

À minha mãe, Patricia Pfaffmann Diniz Moreti e ao meu pai, Carlos Eduardo Moreti, por terem me dado todo o apoio para vir estudar em São Paulo e por se mostrarem sempre tão presentes e atenciosos nos momentos em que eu mais precisei, não existem palavras que explicitem a gratidão que sinto pelo o que vocês fizeram por mim.

Ao meu irmão, Thiago Pfaffmann Diniz Moreti, por se mostrar presente nos momentos difíceis e por ter me ajudado quando que eu precisei.

Ao meu primo, Rodrigo Piloto Moreti, por ter me dado todo o suporte emocional para eu permanecer firme na minha jornada, se mostrando sempre presente e tão amoroso comigo.

À minha amiga, Sandra Saraceni, por ter me acolhido em São Paulo, ter se mostrado uma amiga muito fiel e por ter me ajudado em todos os momentos de dificuldade e também estado presente em todos os momentos de alegria, comemorando e vibrando comigo.

Às minhas amigas, Tatyanna Leuzinger e Laura Ferraz, que me acompanharam desde o início, por terem se mostrado tão companheiras nos momentos em que eu precisei e por terem vibrado comigo cada conquista alcançada. Agradeço também às minhas amigas Isabelle Galindo, Leticia Matias e Kary Visoto por terem estado ao meu lado e terem me dado forças para eu continuar correndo atrás do meu sonho.

Obrigada a todos(as) de coração. 



\section{RESUMO}

MORETI, Priscila Pfaffmann Diniz. Os estudos do futuro e a sua relação com o processo de inovação nas organizações. 2018. 132 f. Dissertação (Mestrado em Administração) Faculdade de Economia, Administração e Contabilidade, Universidade de São Paulo, São Paulo, 2018.

Nesta pesquisa foi estudada a utilização do corporate foresight como forma de suporte ao processo de inovação empresarial. Assim, dentre os objetivos de pesquisa encontram-se: analisar quais são os principais métodos de prospecção utilizados pelas empresas; se existe um foco em alguma inovação específica, podendo ser essas: inovação de produto, processo, marketing, organizacional e/ou modelo de negócio; além de estudar a relação existente entre o corporate foresight e a inovação nas empresas. A metodologia de pesquisa é descritiva exploratória de caráter quantitativo, tendo como principal intuito, entender e descrever a relação entre as variáveis estudadas. Os dados foram coletados a partir de uma amostra não probabilística por tratar-se de uma amostragem selecionada intencionalmente de atuais executivos do mercado. Referente aos resultados ligados ao corporate foresight foi identificado que as empresas utilizam com maior frequência os métodos de Pesquisa de Mercado; seguido de Cenários; Previsões e Projeções de Executivos e Palestra com Especialistas. Quando se trata do horizonte de tempo, nota-se que dos quatro métodos mais utilizados, três visam a prospecção em curto prazo, trazendo assim, a visão de as empresas terem de antecipar-se ao futuro próximo devido ao crescimento tecnológico acelerado. Os resultados de inovação mostram que as empresas estão utilizando com maior frequência as inovações de produto, processo e o crescimento da utilização da inovação de modelo de negócios que demonstra a preocupação das empresas em não só inovar, mas sim em gerar valor para o seu consumidor final. Outro ponto é o modo que as empresas inovam, que, por meio dessa pesquisa, foi possível observar que existe uma tendência em utilizar a inovação aberta de forma individualizada e em conjunto com os modos centralizado e descentralizado. Por meio dos resultados ligados ao suporte que o corporate foresight fornece ao processo de inovação empresarial, foi possível observar que os executivos enxergam os métodos de prospecção como uma forma de suporte à inovação, e que esse suporte é utilizado com maior ênfase nas fases iniciais do processo, como a identificação de inovações estratégicas e em menos frequência na fase de construção de um cronograma factível quando a inovação já foi executada. Além disso, o nível de integração entre os métodos de prospecção e o processo de inovação mostra tendência de ser cada vez mais integrado, tornando essa relação mais madura e desenvolvida. Por fim, os executivos encontram-se, em sua maioria, satisfeitos com a utilização do corporate foresight como forma de apoio ao processo de inovação.

Palavras-chave: Corporate Foresight. Processo de Inovação. Inovação. Futuro. Métodos Prospectivos. 


\begin{abstract}
MORETI, Priscila Pfaffmann Diniz. The future studies and your relationship with the innovation process in the organizations. 2018. 132 f. Dissertação (Mestrado em Administração) Faculdade de Economia, Administração e Contabilidade, Universidade de São Paulo, São Paulo, 2018.
\end{abstract}

The use of corporate foresight as a way to support the business innovation process has been studied in this research. Therefore, among the research objectives are: to analyze which are the main foresighting methods used by the companies; if there is a focus on some specific innovation, such as: product, process, marketing, organizational innovation and/or business model; in addition to studying the relationship between corporate foresight and business innovation process. The research methodology is descriptive exploratory and quantitative, as main concern, to understand and to describe the relation between the variables studied. The data were collected from a non-probabilistic sample because it was an intentionally selected sample of current market executives. Regarding the results related to corporate foresight, it was identified that companies use Market Research methods more frequently; followed by Scenarios; Executive Predictions and Projections and Lectures with Specialists. When it comes to the time horizon, it can be seen that of the four most used methods, three are aimed at short-term prospecting, thus bringing the view that companies have to anticipate the near future due to accelerated technological growth. Innovation results show that companies are increasingly using product, process, and business innovations that demonstrate the concern of companies to not only innovate, but to aggregate value for their final customers. Another point is the way companies innovate, which, through this research, it was possible to observe that there is a tendency to use open innovation in an individualized way and together with centralized and decentralized modes. Through the results related to the support that corporate foresight provides to the process of business innovation, it was possible to observe that executives see prospection methods as a form of support for innovation, and that this support is used with greater emphasis in the initial phases of the process, such as the identification of strategic innovations and less frequently in the construction phase of a feasible schedule when the innovation has already been implemented. In addition, the level of integration between prospecting methods and the innovation process shows a tendency to be increasingly integrated, making this relationship more mature and developed. Finally, executives are mostly satisfied with the use of corporate foresight to support the innovation process.

Key-words: Corporate Foresight. Innovation Process. Innovation. Future. Foresighting Methods. 


\section{LISTA DE FIGURAS}

Figura 1 - Ilustração da Teoria de Schmookler ............................................................................ 51

Figura 2 - Modelo conceitual teórico adotado nesta pesquisa ............................................................... 71

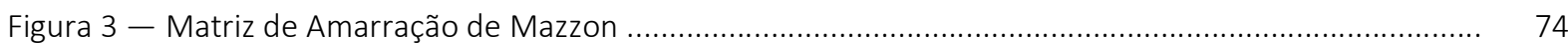




\section{LISTA DE QUADROS}

Quadro 1 - Valores possíveis de serem criados com o uso do corporate foresight ................................... 34

Quadro 2 - indicadores de mensuração relatados por meio de outputs de inovação .................................. 56

Quadro 3 - Exemplos de inputs possíveis de um processo inovador ....................................................... 59

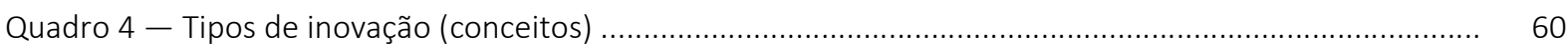

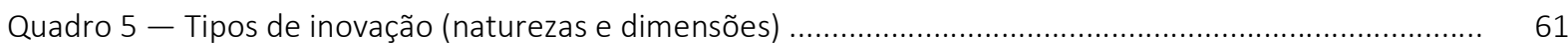

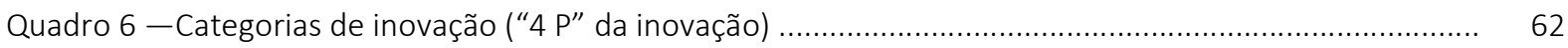

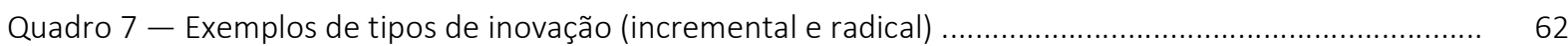




\section{LISTA DE FÓRMULAS}

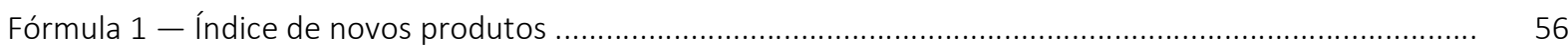

Fórmula 2 - Indicador de produtividade no desenvolvimento de novos produtos ..................................... 57 


\section{LISTA DE GRÁFICOS}

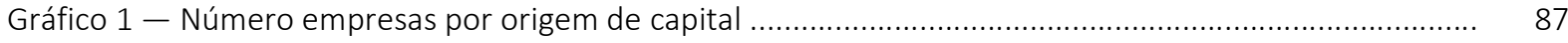

Gráfico 2 - Número de empresas por forma de controle ................................................................. 88

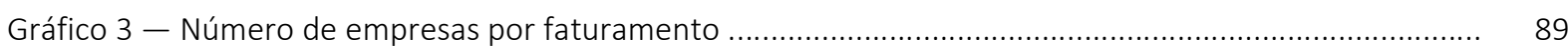

Gráfico 4 - Número de empresas por setor de atuação .................................................................. 90

Gráfico 5 - Número de tipos de inovação por respondente ................................................................. 95

Gráfico 6 - Nível de intensidade entre a prospecção e o processo de inovação ......................................... 102 


\section{LISTA DE TABELAS}

Tabela 1 - Distribuição dos respondentes por cargos ........................................................................ 86

Tabela 2 - Distribuição de frequência dos respondentes por tempo de experiência .................................... 86

Tabela 3 - Distribuição dos respondentes por formação acadêmica …....................................................... 86

Tabela 4 - Frequência de métodos de prospeç̧ão ......................................................................... 91

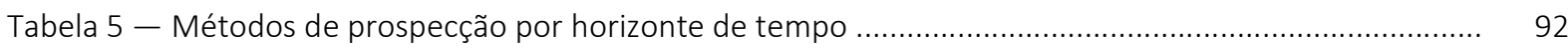

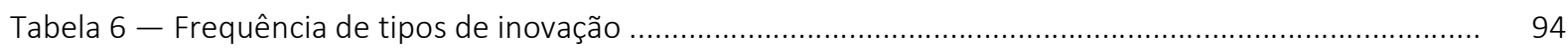

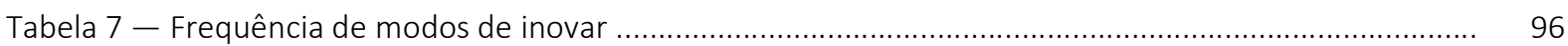

Tabela 8 - Frequência de modos de inovar por tipo de inovação ........................................................... 97

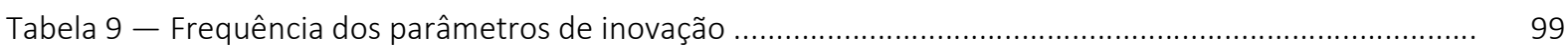

Tabela 10 - Frequência de parâmetros de inovação por tipo de método de prospecção .............................. 99

Tabela 11 - Porcentagens de inovação por tipo de método de prospecção .............................................. 100

Tabela 12 - Frequência de níveis de integração ...................................................................................... 102

Tabela 13 - Frequência de grau de satisfação por tipo de método de prospecção ....................................... 104

Tabela 14 - Frequência em porcentagem do grau de satisfação por tipo de método de prospecção ........... 104

Tabela 15 - Frequência de grau de satisfação por três classes .................................................................. 105

Tabela 16 - Proporção de grau de satisfeitos por tipo de método de prospecção ....................................... 106

Tabela 17 - Frequência de combinação de modos de inovar .................................................................... 110 



\section{SUMÁRIO}

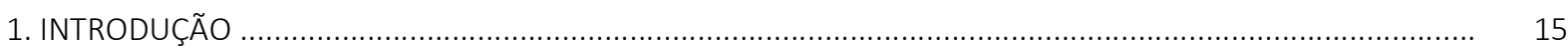

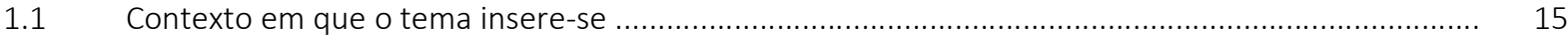

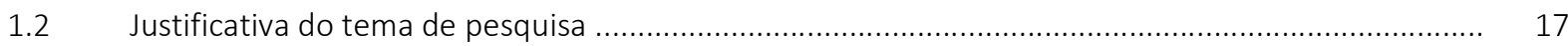

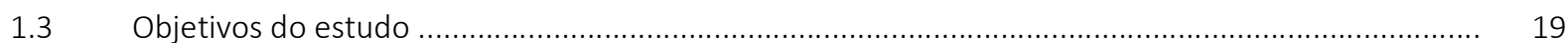

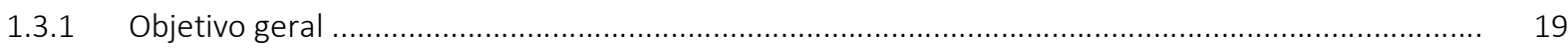

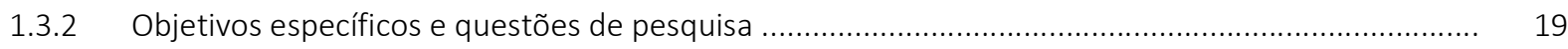

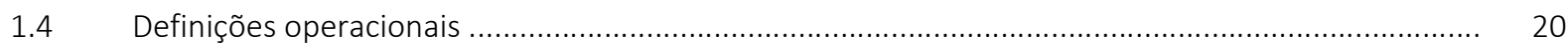

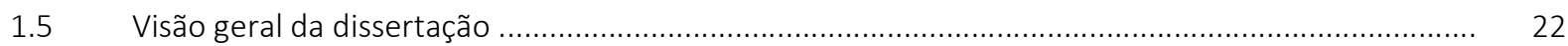

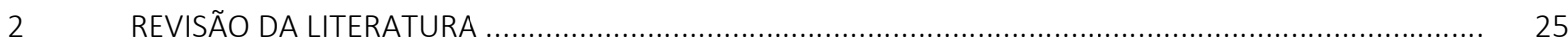

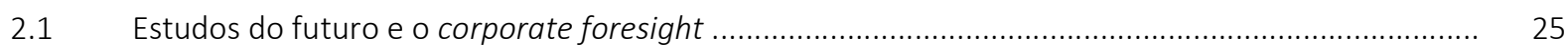

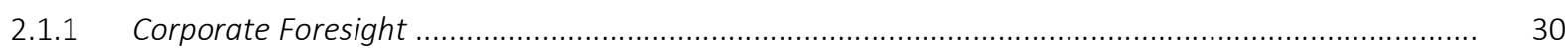

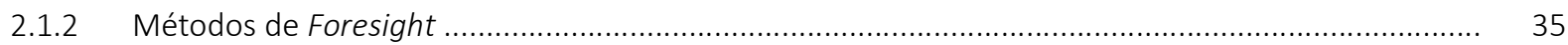

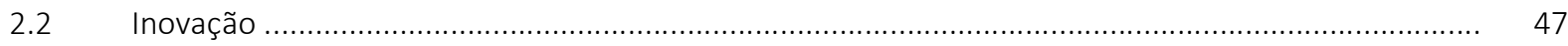

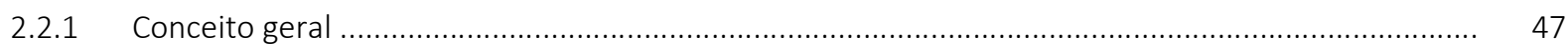

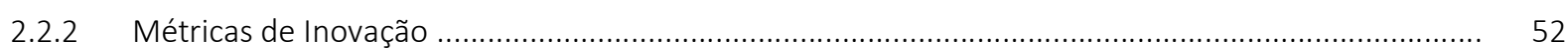

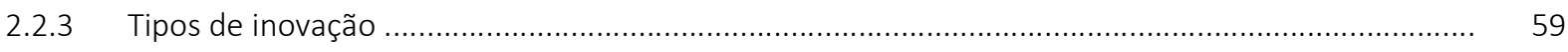

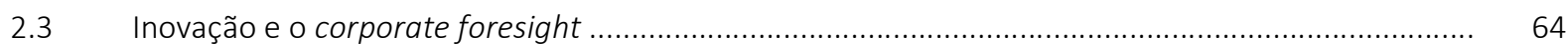

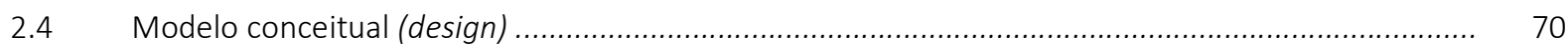

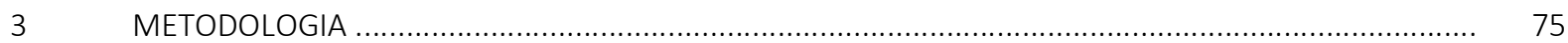

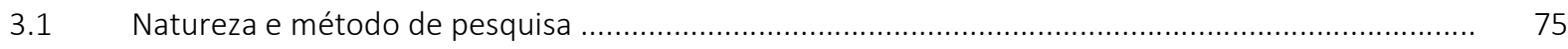

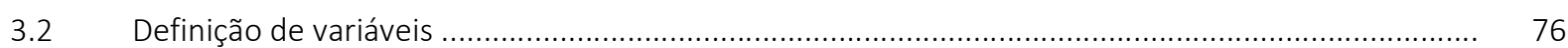

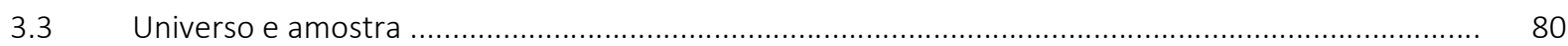

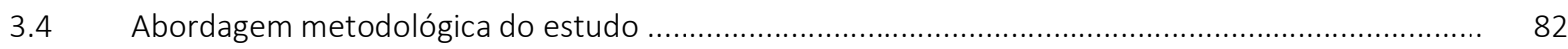

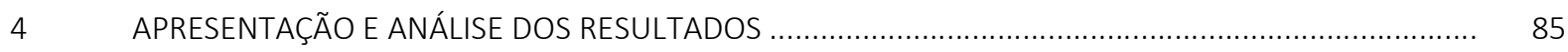

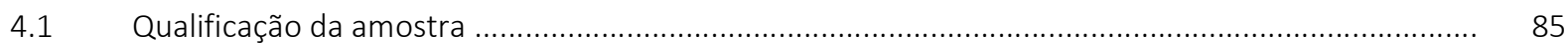

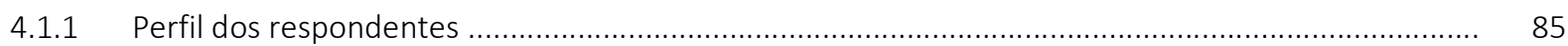

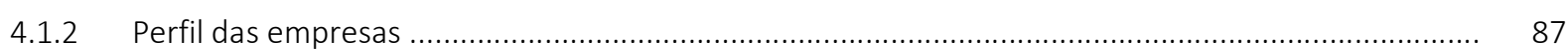

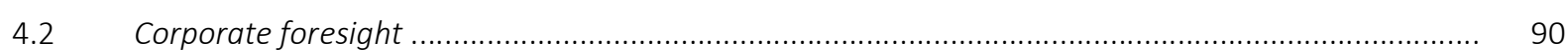

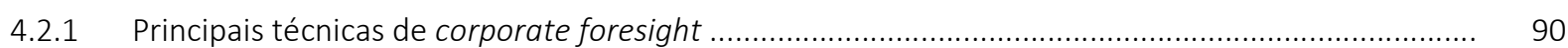

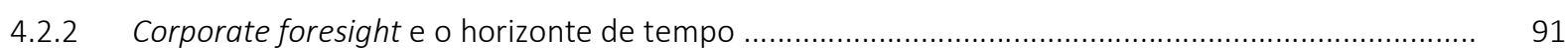

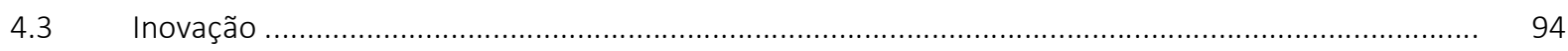

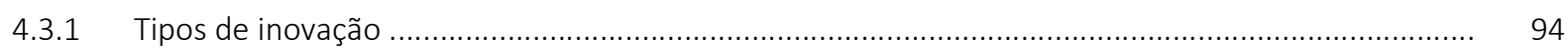

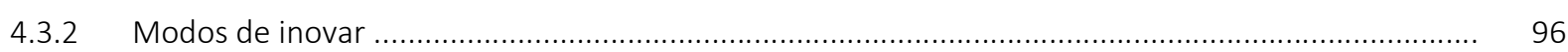

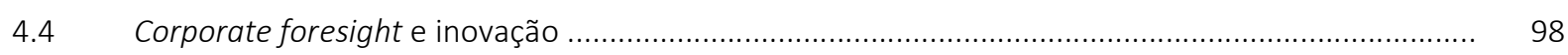

4.4.1 Corporate foresight e os parâmetros de inovação ..................................................................... 98

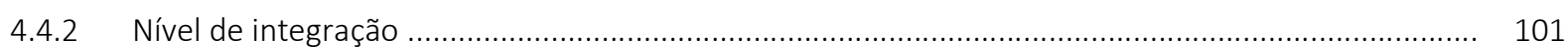

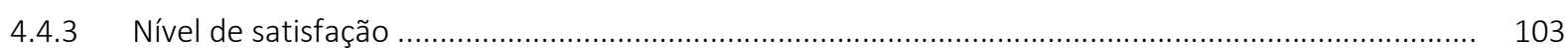

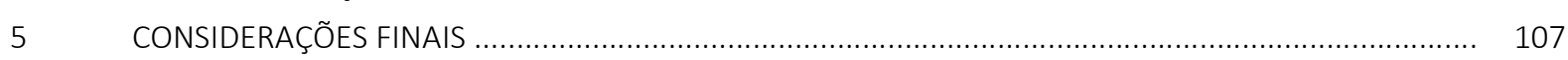

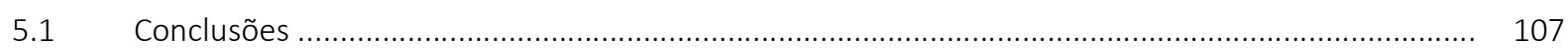

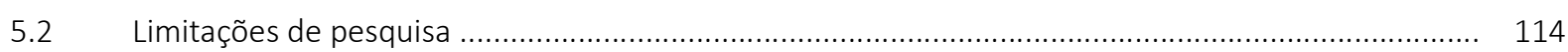

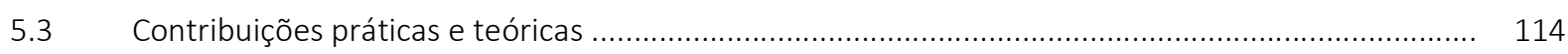

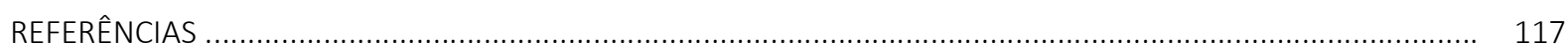

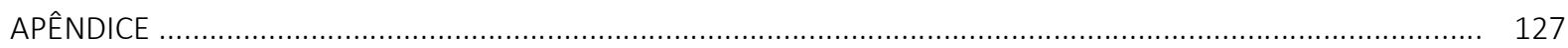





\section{INTRODUÇÃO}

\subsection{Contexto em que o tema insere-se}

De acordo com Heiko, Vennemann e Darkow (2010), nas últimas décadas, um grande desafio começou a ser estabelecido para empresas de todos os portes, que as definiria como bemsucedidas ou não. Esse desafio se encontra na busca de informações qualificadas e estratégicas que faz com que essas empresas possuam vantagem competitiva perante seus concorrentes.

Dessa forma, surge o conceito que permeia a nova era: "The knowledge economy" - que, segundo Powell e Snellman (2004), é definido como produção e/ou serviços baseados na busca de conhecimentos intensivos que contribuem para a aceleração de evoluções técnicas e avanços científicos, bem como a mitigação de rápidas obsolescências. De acordo com uma pesquisa realizada pela McKinsey, em 2006, cujo tema central é a análise de tendências globais e estratégia empresarial, verificou-se que a maior facilidade de obtenção de informação e a criação de conhecimento são percebidas por executivos como uma das tendências mais influentes no mundo atual de negócios.

Assim, informação e conhecimento, tanto atuais quanto futuros, são fatores-chave para a geração de mudança. Porém, existe uma dúvida em relação ao que exatamente define informação, por isso, o conceito é considerado amplo, e possui delimitações diversas na literatura. Zins (2006) considera os dados como um material inicial para geração de informações, e também um material prévio para a obtenção de conhecimento.

Além disso, entende-se que existem formas para atingir esse grau de conhecimento necessário. Surgem assim, métodos e modelos específicos os quais possuem o objetivo em comum de sistematizar o conhecimento e colocá-lo de forma que agregue valor ao assunto estudado. Johannessen, Olaisen e Olsen (1999) explicita que o conhecimento em si não é construído de fatos objetivos, mas é um modo de organização de nossa experiência, seja ela qual for. Portanto, é crucial para as empresas estabelecerem formas e métodos sistemáticos de gestão do conhecimento, e o corporate foresight é um desses métodos (Heiko et al., 2009). 
Tudo isso ocorre, porque começa a ser exigida uma nova mentalidade por parte das empresas. Essa mentalidade envolve mudanças de perspectivas, principalmente relacionadas à antecipação do futuro (Ratcliffe, 2006). Além do mais, considera-se, nessa adaptação das empresas, a inclusão de atividades colaborativas relacionadas especialmente à inovação. Sobretudo, a grande questão envolvida, nesse contexto, é a capacidade de enfrentar incertezas e mudanças, muitas vezes, imediatas.

Rohrbeck e Gemünden (2011) também concordam que o corporate foresight pode ter o caráter de suporte que renova o portfólio de recursos estratégicos passíveis de serem utilizados dentro do meio corporativo. E esses recursos estratégicos são evidenciados como a base fundamental da vantagem competitiva de uma empresa, trazendo, com isso, a importância de utilizar-se as facetas de estudos do futuro como um instrumento válido para ganhar-se vantagem competitiva dentro de seu mercado de atuação.

Portanto, surge a importância de citar quais tipos de metodologias são criadas para tais fins. Assim, as técnicas de estudos do futuro estendem-se a metodologias como, por exemplo, Pesquisa Delphi, métodos de cenários, análise bibliométrica e de patentes, roadmaps tecnológicos, análise morfológica, que serão todos tratados mais à frente, no tópico de revisão da literatura. Cuhls (1998) observa que Delphi são monitorados e muito usados por empresas. De forma complementar, Schwartz (1991) avalia o método de cenários como um método que possui um impacto positivo no mundo corporativo.

Como citado por Peters (1988), a inclusão da inovação faz parte de um processo orgânico que as empresas estão tendo de passar: logo, melhor que esse processo seja feito de forma antecipada e planejada, do que algo que faça muitas empresas, até mesmo, não existirem mais, por não terem tido a capacidade de adaptar-se. Assim, existem estudos que analisam a utilidade das técnicas de estudo do futuro como uma ferramenta de auxílio a estratégias ligadas à inovação. De acordo com Ashcroft (2004), profissionais que lidam com a geração de informação devem estar cada vez mais atentos a mudanças, como por exemplo, desenvolver habilidades de avaliação de estratégias para novas tecnologias.

Novas tecnologias entram no contexto que será tratado nesta pesquisa, que é a inovação. O termo "inovação" vem popularizando-se e tornando-se tema de estudos aprofundados. Desde 
o começo do século XXI, pesquisas tornaram-se frequentes, nesse campo, porém, ainda existem controvérsias a respeito de definições do termo, e principalmente, quando se trata de mensurar os resultados financeiros ligados à geração de inovação dentro de organizações. De acordo com Porter e Millar (1985), inovação empresarial é a ferramenta-chave para enfrentar desafios futuros.

Uma referência que trata intensamente sobre essa questão é Heiko et al. (2010): eles explicam que o corporate foresight é um excelente suporte de decisões, quando se trata de inovação. Os autores desenvolvem sua linha de raciocínio, dizendo que existem duas formas que os estudos do futuro podem contribuir para que os processos de inovação aconteçam de forma orgânica para as empresas, sendo esses: antes da ideia surgir, levando em consideração que essa ferramenta auxilia de forma criativa a gerar, assim, novas ideias para futuras inovações; e segundo, o foresight também contribui para ideias ligadas à inovação, já, então, préestabelecidas.

Portanto, analisar o impacto de técnicas de estudos do futuro na geração e corroboração de inovações no meio corporativo mostrou-se uma lacuna passível de estudo. Com isso, o presente trabalho vai ao encontro dessa problemática.

\subsection{Justificativa do tema de pesquisa}

Segundo Hines (2002), à medida que as organizações tornam-se mais comprometidas com a geração de inovação, juntamente com as práticas de foresight, elas estão procurando mecanismos, princípios, abordagens e ferramentas para a melhor entrega de resultados a seus acionistas. E é exatamente nesse ponto que as técnicas de foresight entram fortemente para auxiliar nessa melhor entrega.

Hines (2002) ainda complementa que existem quatro necessidades-chave que uma organização irá olhar de forma especial, e que podem ser sanadas com a boa utilização de técnicas de estudos do futuro, que são:

I Ter uma posição mais voltada para o futuro;

II Pensar de forma mais sistêmica e aprofundada; 
III Ser mais criativo;

IV Lidar melhor com possíveis mudanças.

A partir de então, Heiko et al. (2010) complementa, dizendo que a academia tem identificado o corporate foresight como um estudo orientado para questões futuras focadas no nicho corporativo. E que esse estudo, juntamente com o fomento da inovação dentro das organizações, é uma potencial forma de lidar de modo efetivo com demandas econômicas.

Ainda, segundo o autor, o corporate foresight é um conceito que presta uma grande atenção à complexidade e à dinâmica do desenvolvimento futuro, assim como a suas interdependências. Tessun (2005) corrobora esse pensamento, argumentando que essa questão encaixa-se, ainda melhor, como uma forma de suporte a decisões ligadas à inovação.

Sendo assim, a inovação possui um foco recente e significante, quando se trata de estudos do futuro. Rohrbeck e Gemünden (2011) dissertam, justamente, sobre a questão que a aplicação das técnicas de estudos do futuro amplia a capacidade de inovar de uma organização. Dentre essas inovações, encontram-se as incrementais e também as radicais, que comportam o lançamento de novos produtos e/ou serviços com pressupostos tecnológicos. Esse conteúdo sobre tipologias de inovação será tratado de forma aprofundada, neste trabalho.

Além do mais, as contribuições desse estudo podem ser divididas em teóricas e práticas. Em relação às teóricas, este estudo proporciona um preenchimento de uma lacuna da literatura referente a estudos que unem os conceitos de foresight e inovação. Pode-se observar, por meio do estudo bibliométrico, que o número de artigos encontrados no campo da administração relacionados a essa união de conceitos é pequeno. Com isso, possibilita-se, assim, dar um enfoque especial ao tema, no campo acadêmico, para que, consequentemente, sejam fomentadas as pesquisas acadêmicas na área, além de salientar a importância do mesmo.

Do ponto de vista das contribuições práticas, um estudo como este pode ser caracterizado como uma fonte de apoio para todas as empresas que possuem como estratégia a evolução tecnológica de seus produtos / serviços. É possível tirar conclusões enriquecedoras, e assim, aplicá-las nos ambientes corporativos, sendo tais conclusões ligadas à pergunta-problema de 
pesquisa, que indaga sobre se a utilização dos métodos de estudos do futuro é um auxiliador positivo no processo de inovação. A partir dos resultados gerados, gestores poderão analisar a possível implementação dessas técnicas em suas empresas, com um grau de confiança maior, ligado ao fato de que essa utilização irá gerar resultados positivos a seus avanços tecnológicos.

Portanto, com base no que foi explanado, e tendo como pressupostos a lógica e contextualização do tema, o presente trabalho busca responder a seguinte indagação: o Corporate Foresight é útil para apoiar o desenvolvimento do processo de inovação nas empresas?

\subsection{Objetivos do estudo}

A pesquisa tem os seguintes objetivos (geral e específicos):

\subsubsection{Objetivo geral}

O objetivo geral desta pesquisa é analisar como a utilização de metodologias de Corporate Foresight pelas empresas que apoiam o desenvolvimento do processo de inovações de produto, processo, organizacional, marketing e/ou de modelo de negócios.

\subsubsection{Objetivos específicos e questões de pesquisa}

Os objetivos específicos deste trabalho são os seguintes:

a. Analisar quais são as principais técnicas de corporate foresight utilizadas pelas empresas respondentes.

b. Analisar se as empresas respondentes possuem algum foco em inovação, considerando as categorias de inovação de produto, processo, marketing, organizacional e/ou modelo de negócios

c. Identificar associações entre a utilização de técnicas de corporate foresight com o desenvolvimento de inovação. 
As questões de pesquisa são oriundas dos objetivos específicos e elas podem ser definidas em:

Q1: Que métodos de corporate foresight são praticados nas empresas?

Q2: Qual horizonte de tempo de utilização das técnicas de corporate foresight?

Q3: Qual o nível de intensidade da relação entre o uso das técnicas de corporate foresight e o desenvolvimento de inovações nas empresas?

Q4: Em qual parâmetro do processo de inovação as empresas consideram que as técnicas de corporate foresight são mais utilizadas?

Q5: Quais tipos de inovação são desenvolvidos nas empresas?

Q6: Existe um foco maior em algum tipo de inovação nas empresas?

Q7: Quais são os modos de inovação mais frequentes nas empresas?

\subsection{Definições operacionais}

Os pressupostos conceituais inerentes a esses estudos estão relacionados aos temas de Inovações e Corporate Foresight, conforme as definições apresentadas, a seguir:

Inovação: neste trabalho, é utilizado o conceito do manual de Oslo, que define inovação como sendo a "implementação de produtos ou serviços novos ou significativamente melhorados, ou um processo, ou um novo método de marketing, ou um novo método organizacional nas práticas de negócios, na organização do local de trabalho ou nas relações externas" (Mortensen \& Bloch, 2005). Esse conceito escolhido foi referenciado no manual de Oslo, pois esse documento é oficial e válido mundialmente.

Tipos de Inovação: em relação aos tipos de inovação utilizados, este trabalho irá utilizar os seguintes conceitos retirados, também, do manual de Oslo (publicado em 2005):

a. Inovações de Produto: introdução de um bem ou serviço que é novo ou significantemente melhorado com respeito às suas características principais ou intenções de uso. Isso inclui melhorias nas especificações técnicas, componentes, softwares incorporados, experiência de uso ou outras características funcionais. 
b. Inovações de Processo: implementação de um novo processo ou de um processo adaptado e melhorado. Isso inclui significativas mudanças em técnicas, equipamentos e/ou softwares.

c. Inovações de Marketing: implementação de um processo novo de marketing envolvendo mudanças significativas no design do produto ou embalagem, praça do produto, promoção do produto ou preço.

d. Inovações Organizacionais: implementação de um novo método organizacional aplicado a práticas de negócios, organização do ambiente de trabalho ou relações externas.

e. Inovações de Modelo de Negócios: além das inovações descritas pelo manual de Oslo (publicado em 2005), existe o modo como essa inovação será apresentada ao consumidor final, que, segundo Chesbrough (2010), é a inovação de modelo de negócio. Assim, de acordo com Chesbrough (2010), esse tipo de inovação pode ser implementado de algumas formas: pela diferenciação do valor criado ao cliente por meio de uma tecnologia; identificação de um segmento de mercado, ou seja, os usuários a quem a tecnologia é útil e para qual finalidade; por meio da definição de uma cadeia de valor necessária para criar e distribuir a oferta tecnológica. Resumindo, Chesbrough (2010) explicita a importância da inovação de modelo de negócio baseada no seguinte princípio, a mesma tecnologia comercializada de duas maneiras diferentes, produzirá dois retornos diferentes, logo não basta apenas inovar, e sim, gerar valor por meio dessa inovação.

Corporate Foresight: o corporate foresight é considerado como a utilização de técnicas de estudos do futuro com o intuito de analisar a evolução a longo prazo de perspectivas dos ambientes de negócios, mercados e novas tecnologias e suas implicações nas estratégias empresarias e inovações. Neste estudo, serão consideradas as seguintes técnicas de estudos do futuro, a partir de uma análise do referencial teórico: técnica Delphi; elaboração de cenários; roadmaps tecnológicos; análises bibliométrica e patentes; análise morfológica; métodos matemáticos; palestras de especialistas; pesquisa de mercado; previsões e projeções de executivos, força de vendas e distribuidores. 
Grau de intensidade da relação entre o foresight e a inovação: é possível identificar três níveis de integração entre as metodologias e os tipos de inovação na literatura, sendo esses um nível mais fraco chamado de ad hoc, um nível de integração médio e um nível de integração total (Van der Duin, 2006).

a. Integração ad hoc: os métodos de pesquisa do futuro e o processo de inovação são entidades separadas e que são combinadas ocasionalmente.

b. Método de integração: os métodos de pesquisa do futuro e o processo de inovação são estabelecidos por um desenvolvimento específico baseado em um método integrado entre ambos.

c. Integração completa: as duas variáveis estão completamente fundidas uma em outra, ou seja, elas começam a ser desenvolvidas ao mesmo tempo na empresa.

Parâmetros de Inovação: segundo Burmeister, Neef e Beyers (2004), existem cinco formas diferentes por meio das quais as metodologias de estudos do futuro podem atuar como suporte ao processo de inovação, sendo elas: a antecipação da procura futura; uma maior qualidade desse processo, por meio de informações importantes; orientação ao contexto inserido; construção de cronograma de inovação factível; e identificação de inovações estratégicas para o seu negócio.

\subsection{Visão geral da dissertação}

Após a discussão inicial do estudo, o documento está dividido em quatro sessões, sendo elas: revisão da literatura, metodologia, discussão dos resultados, e por fim, a conclusão. No tópico 2, referente à revisão da literatura, os temas abordados foram inovação e foresight, sendo esses os eixos teóricos da pesquisa. No subtópico do foresight, foram apresentados os conceitos gerais sobre esse campo de estudo, aprofundados sobre o corporate foresight.

No tópico 3, os aspectos metodológicos da pesquisa são apresentados e discutidos. Dentre os assuntos abordados, encontram-se o método da pesquisa, as variáveis e indicadores utilizados, 
o modelo conceitual, também chamado de design da pesquisa, o universo e a amostra, os procedimentos de campo e o instrumental proposto, as técnicas de análise de dados a serem utilizadas, e por fim, as principais limitações dessa abordagem.

No tópico 4, os resultados obtidos são apresentados e discutidos, trazendo, nessa parte, análises importantes baseadas na coleta de dados e respondendo com propriedade as questões de pesquisa e a pergunta-problema da pesquisa.

No tópico 5 são apresentadas as conclusões e considerações finais do estudo, discutindo-se os principais resultados obtidos, a partir dos objetivos inicialmente propostos e à luz do referencial teórico. 


\section{REVISÃO DA LITERATURA}

\subsection{Estudos do futuro e o corporate foresight}

O futuro é considerado por muitos estudiosos como algo imprevisível, porém, mesmo possuindo esse caráter, os estudos do futuro continuam sendo um recorrente objeto de investigação por parte de gestores, principalmente por motivos de tomadas de decisão mais assertivas. Dois estudiosos da área, Bell (1997) e Dator (2015), possuem visões semelhantes em relação a esse ponto. Segundo esses autores, o futuro não pode ser previsto, logo essa atividade de estudo não pode e não deve ser realizada para tentar prever-se o futuro de forma exata. Deve-se ter em mente o estudo de uma "imagem" do futuro, que apesar de possuir divergências entre as pessoas, deve servir de suporte para ações que podem ser implementadas no tempo presente.

Segundo Heiko et al. (2010) o exame sistemático do futuro, sentido moderno da palavra que engloba estudos e pesquisa do futuro, não é um fenômeno recente, pois esse pôde, até mesmo, ser identificado durante o fim da Segunda Guerra Mundial. De acordo com Gidley (2013), a partir da década de 1960, observou-se um aumento gradativo dos esforços relacionados a pesquisas e aplicação de metodologias de estudos do futuro. Além do mais, McHale (1978) aponta que os estudos do futuro praticamente firmaram-se como uma disciplina quase obrigatória, nos Estados Unidos. Nesse mesmo período, iniciaram-se algumas análises científicas de tendências e indicadores que possuíam esse caráter de predição e antecipação de possíveis eventos.

De acordo com Gidley (2013), existe uma federação ligada aos estudos do futuro, que se denomina "The World Futures Studies Federation" (Federação Global de Estudos do Futuro). A WFSF é considerada relativamente pequena, porém, também, é reconhecida como uma organização não-governamental, dinâmica e global, que vem sendo operada por aproximadamente quatro décadas. Essa federação emergiu de ideias e trabalhos pioneiros de pessoas como Igor Bestuzhev-Lada (Rússia); Betrand de Jouvenel (França, 1903-1987), Johan Galtung (Noruega), Robert Jungk (Áustria, 1913-1994), John McHale (Reino Unido / EUA, $1922-$ 1978), e outros, que, na década de 1960, conceberam o conceito de estudos do futuro em um 
nível global.

O final da década de 1960 e o início da década de 1970 foram um momento emocionante e prolífico para novas ideias, ativismos radicais e também esperanças em ideias e processos transformacionais. Assim, muitas dessas ideias foram coemergentes com as origens da WFSF e seus fundadores (Glidey, 2013). Dentre essas mudanças estavam:

I Inter e transdisciplinaridade;

II Discursos transculturais e transnacionais;

III Feminismo e a luta das mulheres;

IV Novas tecnologias e comunicações;

V Sistemas de ciência de grandes complexidades;

VI Sustentabilidade e limites ao discurso de crescimento;

VII Construção de uma sociedade civil global;

VIII Construção de um repositório global de pesquisas do futuro;

XIX Diálogo global sobre o futuro da humanidade;

X O discurso da globalização e da cultura.

Além do mais, de acordo com Wright e Spers (2006), pensar no futuro de um país, por exemplo, é um desafio metodológico expressivo e que, a partir da década de 1970, com a eclosão da crise de energia, acumularam-se várias reflexões e experiências positivas sobre o tema, no exterior. No Brasil, Johnson, Wright e Guimarães (1986) relatam que existem casos de estudos do futuro sobre produção de petróleo em águas profundas. Existiram, também, experiências em planejamento tecnológico setorial (Johnson \& Marcovitch, 1994). Além disso, Wright e Spers (2006) apresentaram a aplicação da metodologia desenvolvida pelo Programa de Estudos do Futuro da Universidade de São Paulo como uma Política Industrial para o país.

Em parâmetros de definição, Hayward (2005) define o foresight como sendo um atributo, um processo, que tenta ampliar os limites da percepção humana em quatro maneiras:

I No momento de avaliar as ações / decisões do presente, que podem ser consideradas como uma forma de avaliação de consequências. 
II No momento da descoberta / deteç̧ão de problemas futuros antes que eles ocorram, que pode ser tratado como uma função de alerta e orientação prévia, para evitar eventos indesejáveis.

III Ao considerar as implicações atuais de possíveis eventos futuros, sendo uma maneira de formular a estratégia proativamente.

IV Ao prever aspectos futuros desejáveis, o que pode ser chamado, segundo o autor, de cenários normativos.

Schoemaker (1995) argumenta que a prospeç̧ão do futuro também contribui com determinados objetivos que são: saber lidar com situações de incertezas elevadas, quando os gestores sentem-se sobrepujados em sua capacidade de avaliar o que poderá vir a acontecer; segundo, em relação aos casos em que a organização passou por surpresas de grande impacto, no passado, indicando, assim, que seus gestores possam ter limitações para avaliar as possibilidades desse tipo de evento ocorrer; terceiro, quando se observa que os gestores da organização não percebem ou não são capazes de gerar novas oportunidades; e por último, quando a qualidade do pensamento estratégico na organização é considerada relativamente baixa.

Kuosa (2011) traz em sua pesquisa sobre a evolução dos estudos do futuro que existem muitas perguntas referentes ao que se deve fazer quando não se tem certeza do que realmente irá acontecer, que são algumas das indagações mais recorrentes do ser humano. O autor trata desse assunto dizendo, que, naturalmente, há quase tantas respostas para esse tipo de pergunta quanto há de fornecedores de respostas, pois, afinal de contas, segundo sua percepção, os estudos do futuro são um mosaico de abordagens, objetivos e métodos, e muitas partes dele estão em diferentes estágios de evolução.

Assim, uma maneira de abordar essas questões é, primeiramente, estudar os tipos existentes e alternativos para dividir ou categorizar o conjunto básico de práticas, objetivos, interesses do conhecimento, orientações de futuro, abordagens, pontos de vista ou até mesmo a epistemologia ou ontologia de estudos do futuro (Kuosa, 2011).

Uma das abordagens possíveis para categorizar as orientações de pesquisas do futuro é 
método que Borg (2003) utiliza. Ele não divide as pesquisas do futuro em paradigmas abrangentes; ao contrário: ele foca em grandes áreas de pesquisas do futuro que possuem diferentes objetivos finais. Esse autor afirma que a orientação da previsão antiga e a moderna utopia / distopia são consideradas como uma abordagem unificada que pode ser descrita como a primeira grande área das pesquisas do futuro. Essa pode ser definida como criações de imagens, visões e cenários futuros interessantes e relevantes para o que se está estudando.

A segunda grande área de objetivos das pesquisas orientadas ao futuro é a sua capacidade de apoiar o planejamento e a tomada de decisão. Essa aplicabilidade no planejamento de uma organização é o ponto focal dessa segunda abordagem. E a terceira grande área são as questões globais de toda a humanidade, que, segundo Borg (2003), o principal estudioso responsável por essa terceira área é Flechtheim (1972).

Blass (2003) disserta sobre a questão de não ser claro se o termo "estudos do futuro" é considerado um adjetivo ou um substantivo, pois, em um sentido, os estudos do futuro descrevem um campo de trabalho com um interesse comum, e no outro, é uma disciplina por direito próprio. Porém, segundo o autor, esse conceito pode ter começado em uma veia e desenvolvido para a outra, de modo que o grupo de trabalhos descritos como estudos do futuro, com o passar do tempo, tornasse o assunto uma disciplina em si mesma. Slaughter (1998) concorda, dizendo que o foco explícito na negociação de significados é uma das proposições-chave dos estudos críticos do futuro, de modo que a questão de saber se o "estudo" é um adjetivo ou um substantivo é parte do processo crítico propriamente do estudo.

Ainda, sobre a problemática dos objetivos dos estudos do futuro, Dator (2007) explicita grandes linhas de raciocínio ligadas a esse campo, que são:

I O futuro não pode ser previsto, mas alternativas de futuro podem e devem ser analisadas para identificar quais as principais, e quando poderão consolidar-se;

II O futuro não pode ser previsto, mas futuros preferíveis podem e devem ser analisados. O principal objetivo de estudos do futuro é facilitar, para as pessoas, a atividade de formular, revisar, analisar continuamente e implementar os futuros preferíveis;

III Para ser útil, a atividade de estudar o futuro deve ser precedente ao planejamento, à 
estratégia, e assim servir de suporte a decisões orientadas pela estratégia.

Ainda, segundo o autor, a identificação dos principais futuros alternativos e a previsão e criação de futuros preferíveis orientam as atividades de planejamento estratégico subsequentes, que, por sua vez, determinam a tomada de decisão por parte dos administradores de uma organização.

Além do mais, o objetivo de qualquer exercício de estudos do futuro é criar uma visão orientada e não uma "solução final" ou um plano limitado. É apropriado, especialmente em um ambiente de grandes mudanças tecnológicas, ter esse caráter, pois grandes alterações podem acontecer a todo momento.

Segundo outro autor, Gordon, Glenn e Jakil (2005), a utilidade dos estudos do futuro pode ser potencializada ao reexaminarem-se as análises mostradas a seguir, sobre como aprofundar os processos em relação a:

I Integração de novas tecnologias com metodologias de estudos do futuro;

II Redução do domínio do desconhecido;

III Manipulação correta de incertezas do futuro;

IV Facilidade ao se planejar e administrar sistemas não-lineares, operando em ambientes caóticos;

$\checkmark$ Aprimoramento do entendimento dos fatores psicológicos que levam a decisões irracionais;

VI Adequação dos níveis de agregação nos estudos de prospecção;

VII Aproveitamento do potencial das novas fontes de informações sociais.

Relacionado à abrangência do tema, Slaughter (1998) dedica um tópico de seu artigo para explanar sobre o gap que existe no ensino dessa disciplina, em muitas universidades. Segundo o autor, os estudos do futuro têm sido ensinados e propagados em várias universidades, em todo o mundo, por mais de 25 anos, mas, deve-se admitir que muitas dessas universidades têm sido extremamente lentas para aplicar, na prática, essa disciplina. 
Sendo assim, a partir de todas as argumentações lidas anteriormente, é factível pensar-se sobre que os estudos do futuro possuem uma margem excelente para crescimento no ambiente corporativo, como será tratado no decorrer desta pesquisa.

\subsubsection{Corporate Foresight}

Ao longo do tempo, vertentes específicas na área de estudos do futuro, ou seu termo em inglês foresight, foram surgindo. Uma dessas especificidades é o corporate foresight, que se define como busca de informações por meio de técnicas prospectivas no contexto corporativo. Ruff (2006) descreve que, nas últimas três décadas, grandes empresas, em diversos setores como o de energia, automotivo, seguros, telecomunicações e de tecnologia da informação estabeleceram grupos específicos para colocar em prática o corporate foresight do ponto de vista de planejamento estratégico de processos.

Esse ponto de vista possuía como principal objetivo analisar prospecções de longo prazo do ambiente corporativo, como área de marketing e novas tecnologias, além de ter como foco analisar suas implicações para as estratégias empresarias, e também inovação, ponto tratado neste presente estudo. Outros autores também tratam desse escopo de pesquisa com estudos de caso que cobrem diferentes marcas, como em Burmeister, Neef, Albert e Glockner (2002), Davis (2002), Baron, Häußler, Luther e Zweck (2003), Burmeister et al. (2004), Green (2004) e Van der Duin (2004).

Quando se pergunta sobre as direções corretas de uma pesquisa que possui como principal foco o foresight, acadêmicos possuem diferentes conclusões: alguns argumentam que novas ferramentas são requeridas e necessárias; outros apontam um gap de insumos para poder encontrar essas ferramentas corretas, concluindo que, nesse ponto, a educação é necessária para poder alfabetizar as pessoas nesse campo de estudo; um terceiro grupo realça a necessidade de se desenvolverem mecanismos que permitam a participação das partes interessadas para assim aumentar o impacto das atividades prospectivas (Rohrbeck \& Gemünden, 2011).

Pode-se notar que nenhuma dessas perspectivas cita o ambiente corporativo, e é nesse ponto 
que Rohrbeck e Gemünden (2011) argumentam que concordam com todas essas sugestões, sendo assim, essas, válidas, porém nenhuma delas garante o sucesso dos exercícios de prospecção (estudos do futuro) num contexto corporativo. Portanto, é importante possuir um foco de atuação, para, assim, conduzir discussões cada vez mais construtivas, e que agreguem valor, fornecendo inputs para aumento da competitividade de uma empresa.

Sendo assim, a importância do tema, dentro de vários segmentos, torna-se cada vez mais nítida, sendo um desses o corporativo. Ratcliffe (2006) e Hines (2002) possuem a opinião corroborativa de que uma orientação para o futuro juntamente com uma forte capacidade de prospectar, ambos sendo baseados em uma flexibilidade e adaptabilidade de sistemas, é o segredo do sucesso de qualquer organização.

Heger e Rohrbeck (2012) desenvolvem essa problemática, dizendo que, nas últimas décadas, muito conhecimento tem sido gerado para entender melhor como se deve conduzir atividades ligadas ao foresight. Como citado anteriormente, no começo da década de 1960, acadêmicos começaram a estudar programas de foresight nacionais. O maior objetivo era identificar tecnologias futuras que pudessem gerar um grande potencial positivo para o bem-estar econômico. No contexto corporativo, as atividades de foresight têm sido aplicadas para tomar melhores decisões de longo prazo, suportando atividades ligadas à inovação e à estratégia, por meio do mapeamento de alternativas possíveis de se seguir para fomentar tecnologias emergentes e criar cenários futuros.

Segundo Daheim e Uerz (2006), as empresas possuírem essa vontade de se preocupar com o futuro tornou-se "moda" novamente; de acordo com alguns exemplos trazidos pelos autores, é possível enxergar o aumento progressivo de estudos do futuro num contexto empresarial. Uma Telecom alemã (Deutsche Telekom), na segunda metade da década de 1990, trouxe uma ideia simples, mas com um slogan impressionante ("O futuro é feito de ideias"), com o objetivo de trazer a importância do tema. A Siemens, em sua revista interna (Pictures of the Future), destaca a sua pretensão de ser líder na formação do amanhã, com foco em infraestrutura, tecnologia, automotivos e gestão do tráfego, tecnologia de segurança ou tecnologia médica e de saúde. 
Outro exemplo de uma empresa que pretende ser identificada como uma força inovadora e positiva é a Thyssen-Krupp, que reivindica: "nós estamos desenvolvendo o futuro para você". A maior empresa química no mundo, BASF, não só remarcou-se no nível de design corporativo, mas, também, focou em estabelecer uma forte ligação entre a competência químico-técnica da empresa e seu compromisso de "moldar o futuro".

O uso do termo futuro sendo utilizado como um complemento à imagem ou à marca de uma empresa é apenas um lado da moeda desse tipo de estudo. Daheim e Uerz (2006) discutem o papel desse tipo de estudo, que, segundo eles, é cada vez mais utilizado como um valioso input para áreas de planejamento estratégico, investigações, desenvolvimentos tecnológicos e inovação, e também, para comunicação da identidade corporativa. Bezold (2006) agrega, nessa vertente de pensamento, colocando que o foresight nas empresas ganhou, ao longo do tempo, o seu peso e importância como uma ferramenta estratégica de tomada de decisão, a partir do momento em que as áreas de P\&D (Pesquisa e Desenvolvimento) tornaram-se mais complexas e a competitividade no ambiente econômico global tornou-se maior.

Assim, o corporate foresight é considerado, por um número crescente de empresas, como a ferramenta de escolha no momento de preparação dos negócios para o futuro, seja em termos de produção, de visão estratégica, ideias para inovações de produtos ou uns cenários para fins de comunicação (Daheim \& Uerz, 2006). Os motivos identificados por Becker (2002) em que a maioria das atividades de corporate foresight tornam-se válidas são: porque as operações comerciais de uma empresa requerem uma visão de longo prazo - em indústrias que possuem ciclos de produtos longos, como produtos químicos, esse ponto é bastante válido; e outro motivo é o passo proativo para lidar com as incertezas no ambiente de negócios. Nos últimos anos, o corporate foresight tornou-se popularizado, principalmente para atuar na estratégia e inovação, com fins de conectar ou identificar a empresa como uma marca com foco no futuro.

A partir de então, Becker (2002) comenta que o objetivo final de todas as atividades de foresight é servir de suporte para o desenvolvimento de áreas como ciência, tecnologia, e a sociedade, que está disposta a garantir benefícios sociais futuros. Entretanto, todas as atividades de corporate foresight de uma empresa possuem alguns objetivos finais em comum, que segundo o autor são: 
I Inteligência antecipada para prover um background de informações, conselhos futuros diversos e alertas antecipados de desenvolvimentos recentes;

II Definições de direções, como, por exemplo, estabelecer orientações gerais para a estratégia da empresa, mas sem um envolvimento direto nas tomadas de decisão do processo em si;

III Determinando prioridades ou identificando as linhas de P\&D mais desejáveis para se seguir como um input direto de uma tomada de decisão específica (isso também vale para um campo específico, ou como suporte da estratégia empresarial de forma geral);

IV Formulação e implementação da estratégia: nesse caso as atividades de foresight são usadas como uma parte integral da formulação e implementação de decisões estratégicas (a maioria das vezes por meio de um acúmulo funcional, quando a pessoa que está fazendo o foresight também é responsável pelas tomadas de decisão estratégica da empresa);

V Catálise de inovação: em outras palavras, estimular e suportar os processos de inovação entre diferentes partes, sendo elas de dentro da mesma empresa ou não.

Ainda, segundo o autor, quando dirigem a seguinte pergunta para as empresas - quais são os principais motivos para a utilização do corporate foresight? - as respostas vêm divididas basicamente em dois principais motivos, sendo eles: primeiro, é encarado como uma consequência da operação da empresa, que, automaticamente, demanda uma orientação de longo prazo; ou, segundo, essas técnicas de foresight são usadas de forma proativa para lidar melhor com as incertezas do ambiente corporativo como um todo, e na maioria das vezes, lidar com questões externas à empresa.

Típicos drivers internos de uma empresa para utilizar o corporate foresight, de acordo com Becker (2002):

I Estratégias de liderança de inovação, para as empresas conseguirem monitorar e reagir constantemente a atividades de inovação de seus concorrentes;

II Operações comerciais caracterizadas por ciclos de produtos longos, como, por exemplo, setor automotivo ou farmacêutico, em que o monitoramento de longo alcance é um prérequisito para qualquer decisão ligada à pesquisa, tecnologia, desenvolvimento e inovação. 
Típicos drivers externos:

I Utilização do foresight como parte de um sistema de alerta para detectar futuros riscos e oportunidades para preparar-se para possíveis eventos de grandes mudanças;

II Visão do foresight como um recurso valioso para aprender mais sobre novas tecnologias, mercados emergentes e também características comerciais do setor atuante.

De acordo com Rohrbeck (2012), ao rever criticamente o sucesso de pesquisas de futuro, a questão mais feita é sobre se, geralmente, as previsões chegaram realmente perto do fato que estava sendo projetado / estudado. Porém, o que o autor critica é que essa pergunta não é a mais importante e relevante a ser feita. O questionamento que é ignorado, mas que deveria ser pensado é o seguinte: nossas pesquisas de futuro estão criando algum valor? E essa questão, em especial, é completamente cabível num contexto empresarial em que investigações sobre o futuro permanecem frequentemente à margem, não integrada com a gestão operacional e estratégica.

Abaixo segue o quadro 1, com a visão do autor sobre os valores possíveis de serem criados com o uso do corporate foresight:

Quadro 1 - Valores possíveis de serem criados com o uso do corporate foresight

\begin{tabular}{|c|l|l|}
\hline \multicolumn{1}{|c|}{ Grupos } & \multicolumn{1}{|c|}{ Valor criado } & \multicolumn{1}{c|}{ Descrição } \\
\hline $\begin{array}{c}\text { Respostas de } \\
\text { acionamento }\end{array}$ & $\begin{array}{l}\text {-Identificar mudanças externas } \\
\text { relevantes; } \\
\text {-Engatilhar novas iniciativas com } \\
\text { características inovadoras; } \\
\text {-Desafiar o desenvolvimento inovador } \\
\text { para garantir o estado da arte. }\end{array}$ & $\begin{array}{l}\text { Com base em uma exploração contínua do } \\
\text { ambiente, as previsões das atividades } \\
\text { garantem que a empresa responda a } \\
\text { adequadamente para enfrentar ameaças e } \\
\text { oportunidades }\end{array}$ \\
\hline $\begin{array}{c}\text { Começar e facilitar as } \\
\text { discussões estratégicas } \\
\text { para possibilitar } \\
\text { mudanças embasadas }\end{array}$ & $\begin{array}{l}\text {-Desafiar e mudar os modelos mentais } \\
\text { já existentes; } \\
\text {-Moderar discussões estratégicas; } \\
\text {-Promover participações; } \\
\text {-Suportar o rompimento com caminhos } \\
\text { dependentes que devem ser alterados. }\end{array}$ & $\begin{array}{l}\text { A atividade de corporate foresight motiva, } \\
\text { orquestra e conduz discussões estratégicas } \\
\text { Que através da participação ativa de partes } \\
\text { interessadas internas. Estabelecem bases } \\
\text { para mudanças estratégicas corporativas. }\end{array}$ \\
\hline $\begin{array}{c}\text { Identificar e suportar } \\
\text { aquisições de recursos } \\
\text { estratégicos necessários }\end{array}$ & $\begin{array}{l}\text {-Procurar novos recursos; } \\
\text {-Decidir sobre o desenvolvimento ou } \\
\text { aquisições de recursos. }\end{array}$ & $\begin{array}{l}\text { A atividade de corporate foresight identifica } \\
\text { recursos necessários para gerar uma } \\
\text { vantagem competitiva e apoiar assim, as } \\
\text { suas aquisições. }\end{array}$ \\
\hline
\end{tabular}

Fonte: Adaptado de Rohrbeck (2012). 
Existem alguns motivos citados na literatura, segundo Rohrbeck (2012), pelo qual as empresas ignoram essa integração das pesquisas do futuro com as suas gestões estratégicas e operacionais. Uma delas é a falta de compreensão e de finalidade de estudos do futuro no ambiente corporativo. E outra razão é a contribuição do valor desses estudos a curto prazo, pois, muitas vezes, é apenas mensurável em longo prazo. Em relação a essa última razão, temse argumentado, no passado, que, quando se pretende avaliar a criação do valor a partir de um estudo do futuro, têm-se de considerar vários tipos de retorno do investimento realizado, incluindo a criação, difusão e absorção do conhecimento gerado para melhorar a tomada de decisão.

Como exemplos de outputs do corporate foresight que servem para a criação de mudanças estão: criação de novos produtos ou categorias de produto; reforço do planejamento estratégico que facilitem a aquisição de recursos estratégicos e desencadeiem discussões na área; atividades de previsão corporativa que contribuam com valor em várias formas e criação de perspectivas futuras de comunicação com investidores (Rohrbeck, 2012).

Seth (1986) traz uma conclusão simples e clara referente ao tema abordado até então, dizendo que pensar no futuro deve ser parte integrante do nosso cotidiano. Deve-se examinar o futuro a todo tempo, e assim, preferir o futuro, trabalhando sempre em prol de metas futuras. Nesse sentido, segundo o autor, o "futuro é hoje", dando-nos, como consequência, os mais poderosos insumos gerenciais e de desenvolvimento para fomentar o ambiente socioeconômico. E isso tudo vem através da famosa "gestão antecipada", ou, também, do chamado corporate foresight.

\subsubsection{Métodos de Foresight}

Esse tópico irá descrever os métodos de foresight mais conhecidos na literatura, sendo eles: pesquisa Delphi; elaboração de cenários; roadmaps tecnológicos; análises bibliométrica e patentes; análise morfológica; métodos matemáticos; palestras de especialistas; pesquisa de mercado; previsões e projeções de executivos, força de vendas e distribuidores.

Os métodos escolhidos, além de serem os mais citados por diferentes autores, podendo ser 
vistos por uma ampla revisão da literatura realizada nesta pesquisa, também foram embasados na pesquisa de Yoshida (2011), que conseguiu verificar que esses são os métodos mais citados por executivos que ainda atuam no mundo corporativo.

De forma mais específica, em sua pesquisa foi relatado que os métodos mais utilizados são aqueles que permitem interação entre pessoas, sendo esses: cenários, pesquisa de mercado, previsões e projeções de executivos, força de venda e distribuidores, e palestras de especialistas, exatamente nessa ordem (Yoshida, 2011).

\subsubsection{Pesquisa Delphi}

Durante a década de 1950, as metodologias do futuro, como método de cenários e pesquisa Delphi foram desenvolvidos. Primeiramente, tratando-se do Delphi, a criação desse método, segundo Skulmoski et al. (2007), foi desenvolvida por Norman Dalkey da RAND corporation, no ano de 1950, para um projeto militar patrocinado pelo Estados Unidos. Ainda, sobre a visão do autor, o Delphi é um processo iterativo usado para coletar e destilar os julgamentos oriundos de uma série de questionários intercalados com feedbacks.

O objetivo principal do método Delphi, segundo Martino (1993), é desenvolver uma técnica para aprimorar o uso da opinião de especialistas na previsão tecnológica. E isso é realizado de acordo com três parâmetros considerados requisitos em uma pesquisa Delphi, sendo eles: o anonimato dos respondentes, a representação estatística da distribuição dos resultados, e o feedback de respostas do grupo para reavaliação, nas rodadas subsequentes.

Rowe e Wright (1999) concordam com os parâmetros, citados acima, dizendo que o método clássico Delphi é caracterizado por quatro fatores-chave:

I Anonimato dos participantes: isso permite que os participantes sintam-se livres para expressar suas opiniões, sem possuir uma pressão social entre os outros especialistas presentes no grupo; as decisões são avaliadas por meio de seus méritos e não pela pessoa que deu a ideia.

II Interação: isso permite que os participantes refinem suas visões em prol do progresso 
coletivo, sendo realizado entre as rodadas da pesquisa.

III Feedback controlado: isso possibilita que cada participante tenha acesso à perspectiva de pensamento dos outros membros do grupo, e provê a oportunidade de o especialista clarear ou até mesmo mudar sua opinião, por meio de uma análise crítica e consciente.

IV Compilação estatística das repostas do grupo: permite, assim, análises quantitativas e interpretações adequadas dos dados.

Segundo Giovinazzo e Wright (2000), em sua formulação original, o Delphi é considerado uma técnica com foco na busca de um consenso de um grupo de especialistas selecionados a respeito de eventos futuros. E essa evolução em direção a um consenso, obtida no processo, representa uma consolidação do julgamento intuitivo desse mesmo grupo de peritos sobre eventos futuros e tendências. Assim, ainda, segundo os autores, pode-se considerar essa metodologia como norteada pelo uso estruturado do conhecimento da experiência e da criatividade de um painel de especialistas pressupondo-se que o julgamento coletivo, quando feito de forma correta e organizada, é melhor do que uma opinião isolada de um só indivíduo.

Um dos pontos diferenciais do questionário Delphi é a utilização da técnica do feedback entre rodadas para facilitar e apoiar a realização de um consenso dos peritos utilizados no processo. Isso é evidenciado por Estes e Kuespert (1976), que enfatizam o fato do feedback estabelecido através das diversas rodadas permitir a troca de informações ricas entre os diversos participantes, e em geral, conduzir a uma convergência rumo a uma posição de consenso.

\subsubsection{Elaboração de Cenários}

Além do método de questionários Delphi, existe o método de cenários, que possui vários teóricos descrevendo sobre a mesma perspectiva, porém com detalhes específicos que os diferenciam. De acordo com Ringland e Schwartz (1998), na década de 1960, o mundo ficou fascinado pelos aparentes triunfos da Ciência. Assim, por exemplo, 27 principais cientistas da época fizeram-se a seguinte pergunta: "O que o mundo quer e quais serão as suas principais necessidades nos próximos vinte anos?". Schnaars (1989) relata sobre essa ampla publicidade e discussões decorrentes desse estouro do tema ocorrido na época. Começaram-se a fazer previsões relacionadas a motéis submarinos, fábricas e centros de recreação alimentados por 
energia nuclear, foguetes para passageiros comerciais, e outros temas completamente exóticos.

O método de cenários foi inicialmente desenvolvido por Herbert Kahn, em resposta às dificuldades enfrentadas para criar previsões com maior acurácia (Kahn \& Wiener, 1967; May, 1996). Kahn trabalhou na RAND Corporation, um instituto de pesquisa independente, com relações bastante próximas da área militar do Estados Unidos. Ele produziu previsões baseadas em vários cenários, construídos com base no futuro, que diferiam em algumas suposições básicas.

Um conceito clássico com uma visão internacionalmente aceita é a de Michael Porter (1986), que explica que um cenário é uma visão internamente consistente do que o futuro poderá vir a ser, e esse tem como principal função a avaliação explícita de premissas de planejamento, além do apoio à formulação de objetivos e estratégias, a avaliação de alternativas, o estímulo à criatividade, à homogeneização de linguagens e à preparação para enfrentar descontinuidades.

Peterson, Cumming e Carpenter (2003) disserta sobre o tema de cenários, trazendo a sua visão de que esse método é uma forma de pensar criativamente sobre possíveis futuros complexos e incertos. A principal ideia é a de o planejamento de cenários considerar variáveis de possíveis futuros que incluem uma série de incertezas importantes no sistema do que necessariamente focar em uma previsão extremamente acurada de um simples e único resultado. Com isso, o autor traz um dos principais pontos dos cenários que é trazer justamente essa visão ampla de possíveis acontecimento futuros, e não somente focar em um resultado, que, muitas vezes, não irá trazer grandes insumos.

Ringland e Schwartz (1998) desenvolvem explicações extremamente importantes para o campo de estudo da metodologia de cenários. Eles citam Porter e Millar (1985), novamente, como já foi exposto, acima, como um autor importante nessa categoria, que define cenário também como "uma visão internamente consistente do que o futuro pode vir a ser, não com uma previsão, mas, como um resultado possível do futuro". Outra definição trazida pelos próprios autores é a seguinte: "parte do planejamento estratégico que se relaciona com as ferramentas 
tecnológicas para gerir as incertezas do futuro".

De forma breve, outros grandes autores e estudiosos da área, como Porter et al. (1991), falam que o uso dos cenários na área de prospecção do futuro, planejamento e análise de estratégias começou logo depois da Segunda Guerra Mundial. O autor continua falando que cenários exigem incorporações de incertezas e isso é descrito quando se elenca uma gama de possibilidades, que se encontram, normalmente, dentro de uma quantidade reduzida de cenários que juntos constituem a prospecção do futuro.

O estudioso francês Godet (1993) explica que os cenários possíveis e plausíveis não são igualmente prováveis ou desejáveis, e com isso, é necessário fazer uma distinção entre os cenários envolvidos e as estratégias dos atores. Além dos autores já citados, encontra-se, também, nessa lista, Schoemaker (1995), que complementa que a técnica de scenario planning é uma disciplina de imaginar possíveis futuros para empresas que possuem uma grande possibilidade de problemas.

Como mencionado anteriormente, os autores possuem uma definição de cenários que partem do mesmo prisma de ideia, porém com algumas especificidades distintas: no caso de Godet, a sua visão engloba um raciocínio mais quantitativo; então, em seu método, são atribuídas probabilidades diferentes para cenários diferentes. Com isso, além dos modelos qualitativos, também existem os quantitativos, que podem ser incorporados aos métodos extrapolativos, que se constituem de técnicas estatísticas e matemáticas que utilizam de dados históricos, ou seja, dados do passado para serem projetados quantitativamente para o futuro.

\subsubsection{Roadmaps tecnológicos}

A prospecção pode ser utilizada para analisar não somente uma tecnologia completa, mas, também, os componentes necessários, para que o total dela possa ser efetivo no momento de sua realização (Yoshida, 2016). Com isso, surge a possibilidade de utilizar-se o roadmap tecnológico, que torna possível desenhar um mapa de etapas ao longo do tempo, conectando os componentes tecnológicos, na linha do tempo, com suas relações de antecedência. Segundo Lee e Park (2005), ao final, o que se obtém é uma visualização de viabilidade da tecnologia 
consolidada, além de ter-se conhecimento de quanto tempo se levaria para que isso ocorresse.

Kappel (2001) define roadmaps, em seu sentido tradicional, como uma metodologia preocupada, na maioria das vezes, com espaço e posição. Segundo o autor, essa metodologia revive a dimensão do tempo, quando se está analisando, por exemplo, um progresso tecnológico. Além do mais, no campo da taxinomia, roadmaps podem ser definidos como documentos que reconhecem os fatores e parâmetros-chave, como: mercado, produtos e tecnologias para uma parte do negócio.

O Technology Futures Analysis Methods Working Group (2004) identificou que a metodologia de roadmaps está sendo amplamente sugerida como uma ferramenta útil para fomentar a inovação virtual pelo fato que os maps facilitam a visualização de novos caminhos tecnológicos possíveis. Paisagens construídas a partir de métricas, representadas por pesos delimitados, podem indicar um valor potencial de uma tecnologia inovadora que pode ser levada para frente por meio das percepções geradas com o estudo dos roadmaps. Até mesmo jogos de inovação podem ser desenvolvidos a partir dessa técnica.

De acordo com Skulimowski e Pukocz (2012), a essência da abordagem do roadmap focado na tecnologia apresenta os seguintes itens:

I Quebrar o ambiente organizacional em camadas correspondentes a grupos interrelacionados por meio de fatores homogêneos, objetivos e operações semelhantes;

II Decompor as relações dentro e entre camadas, onde se faz uma tentativa de classificá-las em fatores específicos;

III Tendo, assim, em conta, as relações temporais entre esses fatores (relações causais e probabilísticas, tendências e cenários, descrições dinâmicas e outros);

IV Criação de diagramas de fatores de dependência entre as diferentes relações, chamados de roadmaps, devido à semelhança aparente entre essas relações.

Sendo assim, essa metodologia pode ser identificada com algumas causas específicas como, por exemplo (Skulimowski \& Pukocz, 2012): 
I Encontrar relações entre os elementos individuais de objetivos complexos relacionados à transferência de tecnologia, bem como analisar as suas relações de causa e efeito;

II Adaptação do planejamento estratégico em questões tecnológicas;

III Apoio à decisão criativa, através de um conhecimento holístico do contexto do problema analisado.

\subsubsection{Análise Bibliométrica e Patentes}

Além das técnicas já citadas - Delphi, Cenários e Roadmaps - existem várias outras metodologias; dentre elas, encontra-se o uso de análise de patentes, principalmente quando se trata de estudos focados em tecnologias. Segundo Daim, Rueda, Martin e Gerdsri (2006), as patentes são bastante úteis para análises competitivas e tendências de análises tecnológicas. Como já notado, as patentes costumam ser citadas como uma forma de análise no campo de P\&D para alcançar posições competitivas e evitar violações de direitos alheios. Mas, as análises de patentes também são válidas para derivar informações sobre um campo industrial específico ou analisar tecnologias com fins de previsões.

Outra técnica de foresight é a elaboração de análises bibliométricas, que, segundo Norton (2001), pode ser definida como uma técnica de mensuração de textos e informações. Daim et al. (2006) complementam, explicando que, historicamente, o método de bibliometria tem sido amplamente usado para analisar curvas históricas de citações acadêmicas, ajudando, assim, a entender o passado e potenciais tendências futuras. Além disso, a bibliometria auxilia a explorar, organizar e analisar grandes quantidades de dados históricos, ajudando pesquisadores a identificar padrões importantes.

Importantes estudos foram publicados com o cerne da utilização de bibliometria. Morris, DeYong, Wu, Salman e Yemenu (2002) utilizou a visualização de informações oriundas de um banco de dados juntamente com um sistema de análise chamado DIVA, com o qual documentos podem ser visualizados por meio de clusters em um mapa bidimensional. Kostoff, Toothman, Eberhart e Humenik (2001) apresentaram uma espécie de tomografia de um banco de dados para a análise textual do qual se extraiam algumas frases próximas, usando alguns termos específicos como "science citation index" e "engineering compendex". 
Porter e Watts (1997) também apresentaram alguns artigos utilizando essa metodologia com o foco no tema de data-mining. Eles usaram um software chamado VantagePoint. Pilkington (2003) e Pilkington e Teichert (2005) apresentaram aplicações bibliométricas no campo da engenharia, e também referentes a temas ligados à tecnologia. Ambos estudam como a bibliometria ajuda a identificar padrões ocultos de classificação de informações por autores, organizações, países, colaborações, concitações e outros parâmetros.

Assim, a análise bibliométrica ajuda a identificar a área mais falada no momento, as revistas que contêm numerosos artigos dessas áreas que estão em alta, instituições que produzem mais, palavras-chave específicas frequentemente usadas em artigos e referências, e até mesmo, o trabalho que possui maior número de citações.

\subsubsection{Métodos Matemáticos}

Os métodos matemáticos desempenham um papel importante, quando se trata de previsões nos ambientes de negócios. Segundo Makridakis e Wheelwright (1977), a previsão desempenha um papel crucial na área funcional de gestão de negócios, principalmente da época que os autores falam, que era cercada de mudanças substanciais no ambiente econômico, como, por exemplo, a escassez de recursos e o aumento da inflação, no início da década de 1970, seguidos por uma grande recessão.

Georgoff e Murdick (1986) comentam, mais especificamente, sobre os tipos de métodos. Eles classificam métodos que relacionam variáveis entre si, como associação ou causa, com a justificativa deles terem foco em possibilitar a associação entre variáveis ou a identificação de relação de causa entre elas. Além do mais, existem várias dimensões que podem ser agrupadas como metodologias de previsões existentes, como, por exemplo, métodos estatísticos e nãoestatísticos, métodos de séries temporais, e métodos causais (Makridakis \& Wheelwright, 1977).

Yoshida (2011) utiliza alguns métodos matemáticos (técnicas de associação entre variáveis) que serão considerados, também, nesta pesquisa: 
I Correlação: utilizada para a previsão de valores baseados no histórico de covariação entre variáveis;

I Regressão: estimativas geradas por equação ajustada para reduzir-se a variância de uma ou mais variáveis independentes;

III Modelos econométricos: previsões de valores baseadas em integração de equações que representam relações entre diversos elementos da economia, combinando histórico e teoria econômica;

IV Extrapolação de dados históricos: métodos onde se usam séries temporais de dados acumulados do passado para se projetar para o futuro os valores das variáveis de interesse. Técnicas como a de cálculo e projeção de média-móvel, de ajustes de curvas como ajustes exponenciais que são utilizadas para realizar projeções futuras.

Esses métodos, até mesmo por motivos matemáticos, possuem um horizonte de tempo menor, além de serem metodologias baseadas em dados históricos acumulados, que, dependendo da empresa ou do setor, não é possível conseguir um acumulo de muitos anos. Embora, segundo Yoshida (2011), isso dependa da periodicidade em que o fenômeno em análise tem os valores registrados.

\subsubsection{Palestras com especialistas}

Uma forma bastante utilizada de promover ou mesmo iniciar os debates sobre temas em análise para o futuro é fazendo uso de palestras com especialistas sobre temas relacionados ao futuro. De acordo com Georgoff e Murdick (1986) é possível classificar os métodos que utilizam interação pessoal, como métodos baseados em julgamento e opinião de pessoas. É possível, também, incluir desde um simples palpite, onde se aplicam premissas sobre o contexto econômico do próximo ano ou uma simples extensão de fatos corriqueiros, passando por composição de opinião da força de vendas e de executivos, e até o método de cenários anteriormente explicado.

Yoshida (2016) comenta que as palestras de especialistas podem ser consideradas uma forma de introduzir o conhecimento de um especialista em processo de prospecção, que utiliza a interação entre pessoas como a principal forma de conduzir a atividade. Sendo assim, no 
momento que traz o especialista para um debate, o grupo que prospecta o futuro faz ajustes em seu julgamento, e dessa forma, pode encontrar maneiras diferentes de lidar com as incertezas que estão emergidas nas análises.

Não se pode esquecer que outros métodos também utilizam a interação como uma premissa de melhora do processo de obtenção de informações para prospectar-se, como, por exemplo, o método Delphi, explicado anteriormente, e a pesquisa de mercado, que será explicada, logo, a seguir.

\subsubsection{Pesquisa de Mercado}

A técnica de pesquisa de mercado, segundo Yoshida (2016), é baseada em métodos que utilizam estimativas de contagem, de propensão ao consumo, ou uso de determinado produto ou serviço, em distintos mercados segmentados por algum critério de interesse do pesquisador. Assim, o método é realizado por meio de pesquisas que buscam ter como respostas padrões de propensão à aquisição, atitude ou intenção de compra por parte das pessoas, ou seja, possui um maior foco no entendimento futuro das intenções de compra, sendo possível identificar, nesse processo, características tecnológicas valorizadas pelo público-alvo do produto ou serviço.

O conceito formal de pesquisa de mercado deriva de um conceito inicial de pesquisa de marketing definido por Kolter e Keller (2006) como: "[...] a elaboração, a coleta, a análise e a edição de relatórios sistemáticos de dados e descobertas relevantes sobre uma situação específica de marketing enfrentada por uma empresa". Assim, o conceito de pesquisa de marketing é mais abrangente por possuir tanto foco na análise de problemas, como, até mesmo, identificação de oportunidades específicas.

Devido ao fato desse presente estudo não ser focado estritamente na resolução de problemas de marketing, optou-se por adotar um conceito mais restrito como uma metodologia de prospecção é a pesquisa de mercado. Segundo Kotler e Keller (2006), esse é um dos meios pelos quais uma pesquisa de marketing pode ser realizada. 
2.1.2.8 Previsões e projeções de executivos, força de venda e distribuidores

Existem alguns métodos que são baseados em julgamentos de pessoas potenciais para tomadas de decisão dentro das empresas. Esses métodos podem possuir o objetivo de prospectar para curto ou até mesmo longo prazo, que é caso do método Delphi e de criação de cenários, previamente explicados. Os métodos de julgamento baseados em um horizonte de tempo mais curto abarcam as precisões e projeções de executivos, força de venda e distribuidores.

Segundo Georgoff e Murdick (1986), as definições dessas metodologias são as seguintes:

I Previsões e Projeções de força de vendas, de distribuidores e fornecedores: obtidas pela soma das projeções das áreas de vendas diretas e indiretas, com ajustes para redução de eventuais vieses que possam conter as diversas fontes de estimativas consultadas;

II Previsões e Projeções de executivos: representam o consenso de um grupo de executivos sobre que valores, no futuro, poderão ter as variáveis em estudo. Tipicamente, os executivos são de uma mesma organização ou de um setor em comum, e podem ser de organizações que se encontrem antes ou depois na cadeia de valor.

\subsubsection{Análise Morfológica}

Segundo Ritchey (2008), a análise morfológica é um método para estruturar e investigar rigorosamente o conjunto de relacionamento de problemas complexos não quantificáveis, podendo ser, até mesmo, chamados de problemas perversos e messes sociais. Esse método é realizado por meio de um desenvolvimento de um espaço de parâmetros discretos das questões complexas do problema a ser investigado, e também os relacionamentos entre esses parâmetros com base na consistência interna. Esse espaço de parâmetro vinculado ao problema é chamado de campo morfológico. Se tiver um suporte computacional adequado é possível tratar esse campo morfológico com modelos de inferência estatística.

Esse campo morfológico também pode ser chamado de caixa morfológica, ou também conhecido como caixa de Zwicky, nome dado em homenagem ao criador na análise 
morfológica. A sua construção é baseada nos parâmetros definidos que são ajustados uns contra os outros em uma forma visual de matriz n-dimensional. Cada célula dessa matriz contém um valor ou condição particular de cada um dos parâmetros e, portanto, marca um estado particular ou configuração do problema analisado (Ritchey, 2013).

A partir de então, a análise morfológica pode ser empregada para os devidos fins como (Ritchey, 2008):

I Desenvolvimento de cenários e laboratórios de modelagem de cenários;

II Desenvolvimento de alternativas estratégicas;

III Analisar riscos;

IV Relacionar meios e fins em espaços políticos complexos;

$\checkmark$ Desenvolver modelos para análise de posição ou de partes interessadas;

VI Avaliar estruturas organizacionais para diferentes tarefas;

VI Apresentar relações altamente complexas sob a forma de modelos visuais compreensíveis, entre outros.

Outros métodos, também citados na literatura com o principal intuito de estudos do futuro em mente, são metodologias focadas em estimativas necessárias de serem feitas no presente para atingir-se futuros preferíveis. Uma forma de realizar isso é utilizar o backcasting, que pode ser traduzido aproximadamente como a atividade de fazer uma projeção para o passado, a partir de um futuro desejado (Wright \& Goodwin, 2009). Nesse caso específico, a prospecção possui uma ordem relativamente inversa, pois possui como principal objetivo desenhar passos para serem dados no presente, a fim de atingir-se um futuro aspirado.

Após a descrição de vários métodos referentes ao foresighting, pode pairar um questionamento de qual método seria mais eficaz para construir um futuro possível. Porém, a grande questão dessa diversidade de opções, quando se trata de estudos do futuro, é conseguir combinar métodos e não os enxergar como métodos exclusivos, assim atingindo o objetivo principal que é enxergar o futuro de forma mais palpável.

A ideia de combinar os métodos de foresight tem uma história longa na literatura, segundo 
Heger e Rohrbeck (2012). Em 1988, Flores e White (1988) propuseram estruturar a literatura relacionada às combinações de metodologias de foresight em duas principais vertentes, sendo elas: primeiramente, "seleção da base que será utilizada na projeção", que irá determinar quais previsões serão incluídas (qualitativa, quantitativa ou ambas); e a segunda é a "seleção da combinação dos métodos", que está relacionada com o modo que elas serão combinadas (sistematicamente ou intuitivamente).

Armstrong (1986) propôs selecionar métodos baseados em suas vantagens e desvantagens; por exemplo, combinando métodos quantitativos e qualitativos. Essa visão é compartilhada por outros dois autores, também, Dryample e Filde (1991), que, em seus estudos, deram algumas recomendações relacionadas sobre quando é melhor utilizar métodos quantitativos ou qualitativos. Ulrich (1983), ao invés de discutir questões relacionadas a esses dois tipos de metodologia, argumentou que o foco deve ser na diferença entre aspectos objetivos existentes e interpretações e perspectivas.

\subsection{Inovação}

\subsubsection{Conceito geral}

Os estudos ligados à inovação estão aparecendo fortemente na literatura, nos últimos anos, e isso pode ser evidenciado por meio das motivações expostas em vários artigos existentes. Wang e Kafouros (2009) expõem que a principal motivação de seu artigo é o gap existente nessa área de pesquisa, e também, a necessidade de clarear as condicionantes-chave que influenciam a performance da inovação.

De acordo com Godin (2002), em 1993, vinte países europeus conduziram uma pesquisa "survey" relacionada às atividades ligadas a inovações. Essa foi a segunda pesquisa padronizada da história da mensuração da ciência e tecnologia - a primeira tinha sido realizada no ano de 1963. Essa survey da década de 1990 foi baseada no manual de Oslo, que é utilizado desde o ano de 1992.

Além do mais, Godin (2002) explica que a Eurostat e o trabalho metodológico da OECD, no 
começo da década de 1990, marcaram o início da padronização do campo relacionada à mensuração de inovações. O principal objetivo dessa época foi desenvolver fortemente indicadores de outputs que pudessem estimar a inovação por meio da mensuração de produtos, processos e serviços, que fossem oriundas de atividades inovadoras.

Esses acontecimentos foram ganhando representatividade, na década de 1990, devido ao fato dessa era ter sido caracterizada, segundo Neely e Hii (1998), por rápidas mudanças no meio social, político e tecnológico. Ainda assim, frases ligadas às palavras globalização, aquecimento global, computador e Internet ganharam espaço no dia a dia das pessoas. Logo, a preocupação em manter-se atualizado e inovador obteve seu importante peso.

A questão de manter-se atualizado perante todas as mudanças ocorridas, principalmente a partir da década de 1990, é inclusive tratada por Porter e Millar (1985), que cita o fato da inovação empresarial ser uma ferramenta-chave para enfrentar desafios futuros. E quando se fala em desafios futuros, o elo torna-se cada vez mais forte e real com técnicas de estudos do futuro, questão tratada neste presente estudo.

Em parâmetros de definição, notam-se duas definições que surgem na literatura. Primeiramente, é a definição de inovação como uma abordagem evolucionária, que, segundo Nelson e Winter (1982), pode ser vista como um caminho dependente de um processo pelo qual conhecimento e tecnologia são desenvolvidos através da interação entre vários atores e diferentes fatores. Os autores ainda complementam, dizendo que a estrutura dessa interação afeta o caminho futuro da evolução da economia. Como exemplo, pode-se ter demanda de mercado e oportunidades de comercialização, nas quais produtos são desenvolvidos e tecnologias tornam-se grandes sucessos.

Próximo a esse conceito está a visão de inovação como um sistema, que, segundo Lundvall (1992) e Nelson (1993), essa abordagem estuda a influência de instituições externas nas atividades de inovação das empresas e de outros atores. É salientada a importância de transferir e difundir ideias, habilidades, conhecimentos, informações e sinais de vários tipos. Os canais que circulam esses tipos de informação são utilizados pelo ambiente social, político e cultural que conduzem atividades e capacidades de inovação. 
O manual de Oslo define inovação como sendo a "implementação de produtos ou serviços novos ou significativamente melhorados, ou um processo, ou um novo método de marketing, ou um novo método organizacional nas práticas de negócios, na organização do local de trabalho ou nas relações externas" (manual de Oslo de 1997). Esse conceito é o mesmo abarcado na terceira edição do manual (Mortensen \& Bloch, 2005).

Além do mais, Tidd e Bessant (2015) definem inovação como um processo de transformação de oportunidades em novas ideias que possuam amplo uso prático. Esses dois autores contemporâneos trazem uma visão de utilidade, na qual as inovações são vistas como um modo de melhorar coisas já existentes ou criar as não existentes. Ainda complementam que "a inovação é movida pela habilidade de estabelecer relações, detectar oportunidades e tirar proveito delas. Sendo assim, esse conceito não só consiste na abertura de novos mercados, mas, também, pode significar novas formas de servir a mercados já estabelecidos e maduros.

No que tange aos conceitos de inovação, pode-se observar vários autores com definições próprias, mas que possuem o mesmo cerne. Segundo o UK Department of Trade and Industry (2002), "a inovação é a boa exploração de ideias". Segundo Rothwell e Gardiner (1985), "a inovação não é apenas a comercialização de um grande avanço no estado tecnológico da arte (uma inovação radical), mas, até mesmo, a utilização de pequena escala no know-how tecnológico (uma inovação adicional ou de aperfeiçoamento)". E para Drucker (1985), "a inovação é a ferramenta específica dos empreendedores, pela qual eles aprofundam-se nas mudanças como uma oportunidade para negócios ou serviços diferentes. Ela pode ser considerada uma disciplina, ser aprendida e ser praticada".

Porter (1990) diz que "as empresas obtêm vantagem competitiva por meio de ações inovadoras. Elas abordam a inovação em seu sentido mais amplo, incluindo tanto novas tecnologias quanto novas maneiras de fazer as coisas". E por fim, Branson (1998) afirma que "um negócio inovador é aquele que pensa 24 horas por dia fora do lugar-comum. Não basta apenas boas ideias; é a combinação de boas ideias, uma equipe motivada e um conhecimento instintivo sobre o que seu cliente quer".

Em 1995, a Comissão Europeia (EC) relatou um resumo do que é considerado inovação, em seu 
relatório chamado "Green Paper". Em resumo, inovação pode ser definida como:

I Renovação e alargamento da gama de produtos e serviços e dos mercados associados;

II O estabelecimento de novos métodos de produção, fornecimento e distribuição;

III Introdução de mudanças na gestão, na organização do trabalho e nas condições de trabalho;

IV Competências profissionais dos empregados.

Além da conceituação da inovação, surgem estudos que explanam sobre o campo tecnológico e suas interfaces. Assim, Dror (1989) comenta que a gestão estratégica da tecnologia tornouse um problema extremamente importante durante a década de 1980. Relacionada à parte conceitual, Mesthene (1986) define tecnologia como "um conhecimento organizado para um propósito prático", e os conhecimentos necessários para as construções de novas tecnologias são oriundos de inovações.

Segundo Neely e Hii (1998), em termos simples, inovação envolve a exploração de novas ideias. Assim, o conceito de inovação é geralmente confundido com o conceito de invenção, porém, existem diferenças importantes entre eles. Essa distinção é explicada por Freeman (1982), com a seguinte citação: "a invenção é uma ideia, um esboço, modelo para um dispositivo, produto, processo ou sistema novo ou melhorado", enquanto "a inovação, em um sentido econômico, é realizada somente com a primeira transação comercial, envolvendo o novo produto, processo sistema ou dispositivo".

De acordo com Schmookler (1966), a maioria das invenções costuma aparecer esporadicamente, mas, a sua exploração é conduzida fortemente por oportunidades econômicas. Consequentemente, deve existir uma correlação entre dados ligados à inovação, patentes e investimento industrial, especialmente investimento em P\&D. Além do mais, segundo o autor, inovações e patentes estão particularmente ligadas ao campo da tecnologia. A figura 1, a seguir, explicita visualmente a teoria de Schmookler 
Figura 1 - Ilustração da Teoria de Schmookler

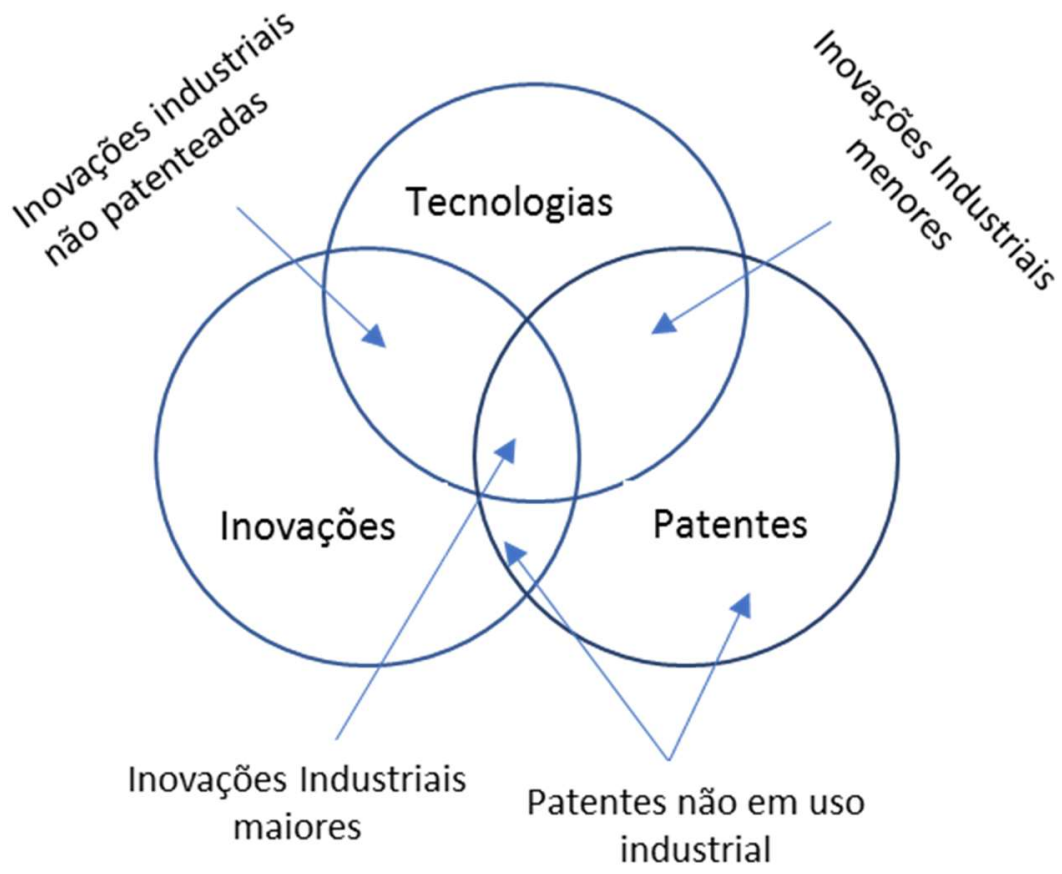

Fonte: Adaptado pela autora. Fonte: Schmookler (1966).

Interpretando a figura 1, o autor considera que os conceitos de tecnologia, patentes e inovação estão intrinsecamente interligados. A partir dessa premissa, considera-se que existam intersecções entre esses conceitos que se pode notar por meio das setas. Schmookler (1966) diz que a inovação, juntamente com a tecnologia, é conhecida como inovação industrial não patenteada; as tecnologias inseridas no conceito de patentes podem ser chamadas de "inovações industriais menores"; a intersecção entre as inovações e as patentes são as patentes não inseridas no contexto industrial, e por último, a união dos três conceitos pode ser chamada de "inovações industriais maiores".

O mesmo autor explana amplamente sobre as inovações industriais; assim, torna-se necessário delimitar conceitualmente esse termo. Segundo Freeman e Soete (1997), a inovação industrial pode ser definida como um conjunto de atividades técnicas, comerciais, de projetos, de manufaturas e/ou de gestão que estão necessariamente envolvidas no marketing de um novo ou aperfeiçoado produto, ou em um primeiro uso comercial de um novo ou aperfeiçoado processo ou equipamento. 


\subsubsection{Métricas de inovação}

O ramo das mensurações é considerado um estudo relacionado e aplicado às Ciências Sociais, que começaram a tornar-se mais evidentes como uma disciplina formal, por volta da década de 1930 (Rossi \& Freeman, 1993). Especificamente, na área da ciência e tecnologia (C\&T), a prática da mensuração possui uma história mais recente, na literatura, e muito menos formalizada. A razão natural para isso acontecer é que a história das intervenções, nessa área, é relativamente curta e atual (Autio, 1998).

Ainda, segundo Autio (1998), a mensuração da performance de inovações não teve um crescimento consideravelmente acelerado até a década de 1980, quando políticas ligadas à inovação começaram a ser desenvolvidas e explicitadas no campo dos sistemas de inovações. Na Finlândia (país referência em inovação), por exemplo, a primeira publicação na área de mensuração da ciência e tecnologia não apareceu antes do fim de 1980 (Grinder, 1990; Guy, Quinta \& Hobday, 1991; Numminen-Guevara, 1992; Lemola \& Siivonen, 1998).

Com isso, o enfoque dado à necessidade de clarear as condicionantes-chave que influenciam a performance da inovação foi ganhando seu espaço na literatura. Segundo Grupp (1994), em termos de resultados de inovação ligados ao mercado, mercados exteriores estão usando indicadores que envolvem a intensidade da utilização de $P \& D$, em produtos como fatoreschave na determinação do sucesso ou não de um processo de inovação.

Kleinknecht (2010) ressalta que políticas públicas, na Holanda, por exemplo, estão crescentemente preocupadas com a promoção de inovações com o objetivo de estimular o crescimento econômico, emprego e sustentabilidade ambiental. Logo, têm-se uma necessidade potencial de conseguir mensurar e acessar essas inovações e mudanças tecnológicas.

A partir dessa necessidade, antes da década de 1970, segundo Godin (2002), a inovação normalmente era mensurada com algumas proxies específicas: dentre as mais importantes, estavam as patentes e os gastos realizados com P\&D. O uso popularizado das patentes como um importante indicador teve como pioneiro o economista Jacob Schmookler, em 1950. 
Alguns anos depois, Godin (2002) comenta que as pessoas que estudavam essa área de pesquisa chegaram à conclusão que patentes não mensuravam corretamente inovação, e sim, mensuravam invenção. Assim, o indicador que prevaleceu como uma proxi adequada foi o "gasto realizado com $P \& D "$.

Entretanto, existem algumas controvérsias, na literatura, sobre se os gastos realizados com P\&D realmente mensuram corretamente a inovação. Segundo Grupp (1994), os resultados de P\&D e os lançamentos bem-sucedidos de novos produtos ou processos não podem ser mensurados por meio dos modos convencionais de se "mensurar" uma variável. Além do mais, uma distinção sistemática do processo de inovação pode ser feita de acordo com as suas várias fases, que incluem os indicadores de despesa, rendimento e retorno (ou outputs).

Assim, segundo o autor, consequentemente a representação do estágio inicial de um processo de inovação pode ser representada com os gastos com P\&D, bibliometria e estatísticas de patentes. Porém, a questão levantada é que nem todo gasto com P\&D corresponde a um resultado de inovação, e nem toda patente criada é convertida fisicamente em uma inovação de produto ou processo.

A partir de então, a grande questão das complexidades no campo da mensuração da inovação é trazida pelo próprio manual de Oslo (Mortensen \& Bloch, 2005), que relata que a inovação é um processo contínuo; logo, empresas praticam constantemente mudanças de produtos e processos, e adquirem novos conhecimentos, tornando, assim, mais difícil mensurar um processo dinâmico (processo inovador) do que um processo estático.

Justamente pelo fato do processo de inovação ser contínuo, ao longo de vários estudos, foram definidas algumas variáveis que se encaixassem de forma lógica, no começo (inputs) e no fim (outputs) de um processo de inovação, para que, assim, criassem métricas factíveis. Segundo Marques (2016), a mensuração da inovação nas organizações adquire um espaço importante na literatura, mediante o estudo de dois fatores, sendo eles o grau de inovatividade e o desempenho inovador. 
Em relação ao grau de inovatividade, entende-se o grau com que a empresa tem a agilidade para adotar inovações por indivíduos ou unidade de adoção, em relação a outros membros do sistema social (Rogers, 1962). Já, quando tratamos de desempenho inovador, é encarado como o desempenho da empresa para a inovação, que, segundo Pereira (2014), tal desempenho pode ser mensurado por uma série de medidas, sendo as mais tradicionais, lucro, produtividade, quantidade e qualidade do trabalho. E quando se trata de inovatividade, alguns indicadores são apontados, logo, abaixo, na categoria de outputs, como por exemplo: introdução de novos produtos (Fremann \& Soete, 2008), e Índices de Novos Produtos (Sbragia \& Kruglianskas, 1998), entre outros.

\subsubsection{Ouputs de Inovação}

A partir da problemática da mensuração de inovação, Rogers (1998) explica que a mensuração da inovação é considerada extremamente complicada por estar lidando com um escopo muito amplo de estudo. Com isso, segundo o autor, um método de tentar acessar a inovação é fazer uma distinção entre os outputs das atividades inovadoras e os inputs. Godin (2002) comenta que somente no final da década de 1970 e no começo da década de 1980, que os indicadores de output começaram a ser coletados de forma sistemática. Em suma, de acordo com Tinguely (2013), esse foco em indicadores de outputs de inovação foi contemporâneo do segundo período de "mensuração da ciência e tecnologia", que tinha como principal objetivo quantificar a C\&T e resultados do governo relacionados a gastos com atividades de pesquisa.

Como observado por Rogers (1998), o principal output de mensuração da atividade inovadora é o sucesso da organização, que pode ser medido por lucro, crescimento da receita, compartilhamento de performance, capitalização de mercado ou produtividade de mercado dentre outros indicadores financeiros. Porém, Gow e Kells (1998) e Rogers (1998) comentam que esses indicadores não refletem diretamente o nível de inovatividade (um dos modos de mensurar inovação), que são justamente pelos outputs e também podem ser o resultado da interação de uma variada gama de diferentes fatores.

Outra alternativa relacionada aos outputs é criar variáveis para o número de produtos novos ou melhorados introduzidos por uma empresa no mercado. Isso pode ocorrer, segundo Rogers 
(1998), por meio de uma survey a qual pergunta diretamente a seu entrevistado final sobre se têm sido introduzidos produtos ou processos novos ou melhorados, obtendo sim ou não como resposta para essas perguntas, o que faz surgir um jeito básico de categorizar empresas dentro de duas categorias: inovadoras ou não-inovadoras.

A ABS pesquisa de inovação aprimorou esse tipo de pergunta, perguntando se a empresas poderiam mensurar, por percentual, quanto representava de sua venda total os novos produtos inseridos, os produtos melhorados e os produtos não modificados, que foram lançados nos últimos três anos. Essa pesquisa ainda abrangeu perguntas relacionadas ao percentual estimado de produtos vendidos, que foram executados por processos melhorados ou recentemente criados. Essas formas de mensuração confiam na habilidade do entrevistado de responder corretamente os dados.

Uma crítica em relação a percentual de vendas de produtos melhorados ou aprimorados é, segundo DeBresson (1996), que o alto percentual desse tipo de vendas não pode ser um bom indicador de performance futura de uma empresa, até porque esses novos / melhorados produtos podem estar sendo vendidos em mercados devassados ou em declínio. Logo, não é uma garantia de sucesso futuro para a empresa.

Outro potencial, exemplo de output, é por meio de estatísticas relacionadas à propriedade intelectual (IP), como, por exemplo, patentes (é um direito de propriedade intelectual que é determinado legalmente e dá o direito exclusivo a seu inventor), marcas comerciais (uma forma de distinguir as marcas de certa empresa de suas concorrentes, por meio de algum símbolo, imagem, qualidade específica ou até mesmo reputação), e designs registrados (pode ser usado para proteger a aparência visual da produção de determinado produto, como formato, configuração, padrões e ornamentações existentes no produto).

A grande questão é a contraposição de alguns autores, como já citado por Godin (2002), em relação à questão de patentes mensurarem invenção ao invés de inovação. Segundo Griliches (1990), Jacob Schomookler, o primeiro economista que estudou intensivamente dados relacionados a patentes, começou sua pesquisa considerando patentes como um output de inovação, porém no final de sua pesquisa decidiu que patentes fossem transformadas em um 
index de invenção principalmente classificado como input do que como output.

O quadro 2 resume os indicadores de mensuração relatados por meio de outputs de inovação:

Quadro 2 - indicadores de mensuração relatados por meio de outputs de inovação

Outputs

Descrição e Comentários

\begin{tabular}{l|l}
\hline $\begin{array}{l}\text { Introdução de novos ou melhorados produtos } \\
\text { ou processos }\end{array}$ & $\begin{array}{l}\text { Pergunta de pesquisa: normalmente, sim / não como respostas } \\
\text { que se referem a pré-determinado período. }\end{array}$ \\
\hline $\begin{array}{l}\text { Percentuais de vendas advindos de produtos } \\
\text { ou processos novos ou melhorados }\end{array}$ & $\begin{array}{l}\text { Pergunta de pesquisa: Se baseia na habilidade do respondente } \\
\text { em responder veridicamente os percentuais }\end{array}$ \\
\hline Estatísticas de Propriedade Intelectual & $\begin{array}{l}\text { Patentes, marcas de mercado e designs registrados. A } \\
\text { desvantagem é que isso não necessariamente representa a } \\
\text { comercialização da ideia. }\end{array}$ \\
\hline Performance empresarial & $\begin{array}{l}\text { Uso de técnicas econométricas para relacionar indicadores de } \\
\text { inovação com a performance empresarial. }\end{array}$ \\
\hline
\end{tabular}

Fonte: Adaptado de Rogers (1998).

Corroborando quadro 2, Deshpandé et al. (1993) apresentam uma escala que tem como foco a introdução de novos produtos ou produtos melhorados, primeiro output citado por Rogers (1998). Essa forma de mensuração é considerada mais simplista por tratar-se de uma mensuração em termos de valores absolutos de inovatividade / desempenho inovador. Outro indicador, mais sofisticado em termos de cálculo, é o índice de novos produtos, apresentado por Tipping, Zeffren e Fusfeld (1995) e Sbragia e Kruglianskas (1998). Esse indicador, em específico, considera o percentual da receita bruta com os novos produtos introduzidos no mercado, nos últimos três a cinco anos, pelo faturamento bruto anual; a fórmula 1, com fins de visualização, encontra-se, a seguir:

Fórmula 1 - Índice de novos produtos

$$
\begin{gathered}
I N P=\frac{\text { Parcela do faturamento anual com produtos de até } 5 \text { anos de vida }}{\text { Faturamento anual da empresa }} \times 100 \% \\
\text { Fonte: Sbragia e Kruglianskas (1998). }
\end{gathered}
$$

Agora, do ponto de vista da inovação de produtos, que também inclui-se entre os outputs de inovação, Cooper e Edgett (2008) também contribuíram para a literatura, apresentando um indicador de produtividade no desenvolvimento de novos produtos: ele relaciona as vendas ou lucros oriundos do desenvolvimento de novos produtos com os gastos em P\&D, conforme a fórmula 2, abaixo: 
Fórmula 2 - Indicador de produtividade no desenvolvimento de novos produtos

$$
\begin{gathered}
N P D \text { productivity }=\frac{\text { Sales (or profits)from } N P D}{R \& D \text { Spending }} \\
\text { Fonte: Cooper e Edgett (2008). }
\end{gathered}
$$

A fórmula 2 pode ser considerada uma forma sistemática de mensurar-se o lançamento de novos produtos, sem ser somente por uma resposta com resultados de valores absolutos de lançamento. Marques (2016) relata que esses mensuradores são interessantes, porque possuem a capacidade de analisar, de forma integrada, mais de uma variável, assim permitindo uma melhor visualização e resultados mais robustos, porém, como desvantagem, exigem certo conhecimento por parte dos respondentes desses dados, para que a qualidade desses indicadores seja garantida; fato esse bastante complicado de resolver-se, pois as empresas não costumam ceder facilmente valores referentes a suas inovações, por serem valores estratégicos e prejudiciais a elas caso os concorrentes saibam.

\subsubsection{Inputs de Inovação}

Agora, em relação aos inputs de inovação, o nível de gastos com P\&D é considerado a proxi mais usada para nível de esforços realizados para fomentar a inovação. A sua vantagem é que, relativamente fácil de compreender o seu conceito, também fornece um valor monetário para usar posteriormente em análises. Segundo o manual de Frascatti, também produzido pela OECD (Mortensen \& Bloch, 2005), define-se P\&D como: “Pesquisa e Desenvolvimento (P\&D) inclui o trabalho sistemático realizado para aumentar o estoque de conhecimento - incluindo o conhecimento da humanidade, da cultura e da sociedade - além de conceber novas aplicações do conhecimento disponível".

Sbragia (1987) relata alguns indicadores de resultado da atividade ligada à P\&D, dentre eles estão nove grandes fatores e seus respectivos indicadores. São eles: competência intrínseca adquirida; potencialidades técnicas construídas; credibilidade interna conquistada; assistência provida à produção; assistência provida a marketing; contribuição para exploração de mercados externos; impacto tecnológico obtido; impacto sobre vendas; e impacto sobre os negócios. 
Assim como nas variáveis de outputs de inovação, a propriedade intelectual também pode ser considerada um input do processo de inovação. O uso dos dados relacionados às patentes tem sido, de longo, a questão mais estudada na literatura. Segundo Griliches (1990), o principal problema do uso das patentes, como um modo de mensurar inovação, é que as invenções que são patenteadas diferem significativamente em suas qualidades, por exemplo: uma patente pode valer milhões de dólares e outras podem não valer nada. Com isso, considerar que uma empresa é inovadora por meio do número de patentes que ela possui pode trazer como resultados dados controversos. Já, Basberg (1987) considera outras duas questões referentes ao uso das patentes no nível organizacional, que são: como as patentes refletem o uso comercial da tecnologia e como a usabilidade do sistema das patentes difere de acordo com diferentes empresas e/ou indústrias.

Além desses autores, existem vários outros que explanam sobre questões específicas das patentes, justamente por ser um assunto ainda polêmico na literatura. De acordo com Smith (2005) e De Rassenfosse (2010) as patentes representam um grande trade-off entre o custo de uma divulgação referente à inovação e o benefício de um monopólio temporário garantido por lei. Patentes também podem ser consideradas, ao invés de um indicador ligado à inovação, um indicador de resultado da estratégia da empresa (Kleinknecht, Van Montfort \& Brouwer, 2002).

Como já discutido antes, sobre os conceitos da inovação, existe uma diferente nítida entre invenção e inovação, até porque nem toda empresa que é considerada inovadora necessariamente precisa inventar a tecnologia ou o processo que está utilizando. Com isso, comprar tecnologias de outras empresas ou instituições pode ser um aspecto-chave para a estratégia inovadora de uma empresa, ponto salientado por Rogers (1998).

Outro input possível são os gastos realizados com marketing para novos produtos existentes. Na realidade, podem ser considerados inputs de inovação todos os tipos de gastos necessários, seja em gestão do processo de implementação ou até mesmo os gastos em marketing para a promoção do produto (Rogers, 1998).

Por fim, abaixo, encontra-se o quadro 3, com exemplos de inputs possíveis de um processo 
inovador:

Quadro 3 - Exemplos de inputs possíveis de um processo inovador

Inputs

Descrição / Comentários

\begin{tabular}{|c|c|}
\hline$P \& D$ & $\begin{array}{l}\text { Amplamente disponível. } \\
\text { Problemas com uma definição precisa, mas não necessariamente } \\
\text { mensura a inovação. }\end{array}$ \\
\hline Estatísticas de propriedade intelectual & $\begin{array}{l}\text { Não coincide necessariamente com a inovação. } \\
\text { Praticamente nenhuma pesquisa sobre marcas e designs } \\
\text { registrados. }\end{array}$ \\
\hline $\begin{array}{l}\text { Aquisição de tecnologia oriundas de outros } \\
\text { (Exemplo: Licença de patentes) }\end{array}$ & Importante elemento da inovação. \\
\hline $\begin{array}{l}\text { Despesas de ferramentaria de engenharia } \\
\text { industrial e startup de fabricação associadas a } \\
\text { novos produtos / processos }\end{array}$ & $\begin{array}{l}\text { Refere-se a capacidade de a empresa distinguir esses tipos de } \\
\text { investimentos de investimentos puramente para reposição. }\end{array}$ \\
\hline Ativos intangíveis & $\begin{array}{l}\text { Balanço Patrimonial irá incluir a capitalização de P\&D; com isso, } \\
\text { mudanças em ativos intangíveis podem caracterizar inovações } \\
\text { recentes. }\end{array}$ \\
\hline \multicolumn{2}{|l|}{ Gastos com marketing } \\
\hline \multicolumn{2}{|l|}{$\begin{array}{l}\text { Gastos com treinamento relacionados a } \\
\text { novos ou melhorados produtos / processos }\end{array}$} \\
\hline $\begin{array}{l}\text { Mudanças na gestão e organização da } \\
\text { empresa }\end{array}$ & Normalmente, perguntas de pesquisa com respostas sim ou não. \\
\hline
\end{tabular}

Fonte: Adaptado de Rogers (1998).

\subsubsection{Tipos de inovação}

O manual de Oslo é conhecido como um importante e relevante documento, quando se entra no mérito de tipificações das inovações, assim sendo amplamente utilizado como base teórica para textos da academia. Ele é desenvolvido pela OECD, que, segundo o próprio manual (Mortensen \& Bloch, 2005), é um fórum único cujos governantes de trinta democracias distintas reúnem-se para discutir sobre economia, ambiente social e desafios da globalização. A sua maioria é composta por membros da União Europeia.

Segundo Pereira (2014), o manual de Oslo é considerado uma referência metodológica para poder construir critérios de avaliação do processo de inovação, mostrando quatro tipos de inovação existentes, os quais abrangem todos os campos em que podem realizar-se as mudanças dentro de um contexto organizacional.

As inovações podem ser divididas em: inovações de produto; inovações de processo; inovações 
organizacionais; e por fim, inovações de marketing. O quadro 4, que foi construído com base nas definições da terceira edição do manual de Oslo, explicita esses quatro conceitos:

\section{Quadro 4 - Tipos de inovação (conceitos)}

Tipos de Inovação

Definição

\begin{tabular}{c|l}
\hline Inovações de Produto & $\begin{array}{l}\text { Introdução de um bem ou serviço que é novo ou significantemente melhorado } \\
\text { com respeito as suas características principais ou intenções de uso. Isso inclui } \\
\text { melhorias nas especificações técnicas, componentes, softwares incorporados, } \\
\text { experiência de uso ou outras características funcionais. }\end{array}$ \\
\hline Inovações de Processo & $\begin{array}{l}\text { Implementação de um novo processo ou de um processo adaptado e } \\
\text { melhorado. Isso inclui significativas mudanças em técnicas, equipamentos e/ou } \\
\text { softwares. }\end{array}$ \\
\hline Inovações de Marketing & $\begin{array}{l}\text { Implementação de um processo novo de marketing envolvendo mudanças } \\
\text { significativas no design do produto ou embalagem, praça do produto, promoção } \\
\text { do produto ou preço. }\end{array}$ \\
\hline Inovações Organizacionais & $\begin{array}{l}\text { Implementação de um novo método organizacional aplicado a práticas de } \\
\text { negócios, organização do ambiente de trabalho ou relações externas. }\end{array}$
\end{tabular}

Fonte: Adaptado do manual de Oslo (Mortensen \& Bloch, 2005).

Os estudos de Joseph Schumpeter tiveram uma grande influência nas teorias de inovação, como já citado anteriormente. Ele explica que o desenvolvimento econômico é guiado pela inovação por meio de um processo dinâmico o qual novas tecnologias substituem as velhas, um processo que ele rotulou como "destruição criativa". Ainda, na visão do estudioso, inovações radicais são o principal fator para mudanças disruptivas, enquanto as inovações incrementais corroboram o avanço na mudança de processos (Mortensen \& Bloch, 2005).

Antes mesmo de começarem as divulgações do manual de Oslo, Schumpeter (1934) propôs uma lista de cinco tipos de inovação, que são base para os conceitos desenvolvidos no manual de Oslo. Eis a lista:

I Introdução de novos produtos;

II Introdução de novos produtos de produção;

III Abertura de novos mercados;

IV Desenvolvimento de novas fontes de fornecedores para commodities ou outros inputs.

V Criação de novas estruturas de mercado para indústrias.

A inovação também pode ser classificada de acordo com a sua natureza, sendo elas: radical 
(exemplo: lançamento de uma nova vacina ou microprocessador); e incremental (exemplo: a introdução de um chip com capacidade de 32-bit por um de capacidade anterior de 16-bit) (Neely \& Hii, 1998). Abaixo segue um framework que os autores dividem em três tipos de inovação que são: produto, processo e organizacional, e suas duas possíveis naturezas ou dimensões: radical e incremental:

Quadro 5 - Tipos de inovação (naturezas e dimensões)

\begin{tabular}{|c|c|c|}
\hline Tipo de Inovação & Incremental & Radical \\
\hline Produto & $\begin{array}{l}\text { Um chip de } 32 \text { bits que substituiu um de } \\
\qquad 16 \text { bits. }\end{array}$ & Lançamento de um compacto tocador de disco \\
\hline Processo & $\begin{array}{l}\text { Melhor do sistema de qualidade de } \\
\text { algum processo de inspeção }\end{array}$ & Prototipagem de produtos de computadores \\
\hline Organizacional & Implementação de ciclos de qualidade & Reuniões por teleconferência \\
\hline
\end{tabular}

É importante frisar que o quadro 5, originado da teoria de Neely e Hii (1998), não abrange as inovações de marketing, pois esse conceito é o mais novo dentro desse campo de estudo; elas são tratadas mais profundamente, a partir da terceira edição do manual de Oslo, ou seja, no ano de 2005

Além desses tipos de inovação (radical e incremental), existe outro tipo, mais recente na literatura, que é a inovação disruptiva. De acordo com Yu e Hang (2010), um tipo de inovação tecnológica emergente é a teoria da inovação disruptiva, popularizada por Christensen (1997). Essa categoria de inovação pode ser definida como um poderoso meio de ampliar e desenvolver novos mercados e proporcionar uma nova funcionalidade, que, por sua vez, pode prejudicar o mercado existente (Christensen, 1997).

Apesar de ser um tema de relevância, na literatura e também na prática, é ainda considerado um assunto complexo de se definir e que traz uma série de divergentes em sua conceitualização. Segundo Yu e Hang (2010), a natureza dispersa e conflitante da literatura em relação à inovação disruptiva, na última década, pode representar uma incerteza para estudos futuros, sendo necessário desenvolver uma revisão mais abrangente para essa conjuntura. Com isso, esse estudo optou por não utilizar o conceito de disruptiva como classificação de inovação, por enxergar que ainda existam conflitos em sua definição, e sim, utilizar o conceito 
de radical e incremental.

Ainda, no que tange aos tipos de inovação, Tidd e Bessant (2015) trazem as categorias de inovação em uma vertente recente, que é chamada de os "4 P" da inovação, que são detalhados no quadro 6, abaixo:

\section{Quadro 6 -Categorias de inovação ("4 P" da inovação)}

"4 P" da Inovação

Definição

\begin{tabular}{l|l}
\hline Inovação de Produto & Mudanças no que produtos / serviços uma empresa oferece \\
\hline Inovação de Processo & Mudanças no contexto em que produtos / serviços são introduzidos \\
\hline Inovação de Posição & Mudanças nos contextos em que produtos / serviços são introduzidos \\
\hline Inovação de Paradigma & Mudanças nos modelos mentais subjacentes que orientam o que empresa faz \\
\hline
\end{tabular}

Fonte: Adaptado de Tidd e Bessant (2015).

Segundo esses autores, tais conceitos de inovação fornecem a estrutura para um mapa do espaço de inovação disponível para qualquer empresa, e um exemplo é a estrutura aplicada a um pequeno negócio.

Seguindo a mesma lógica de Neely e Hii (1998), os "4 P" da inovação também podem ser exemplificados e segmentados em inovações incrementais e radicais. Seguem dois exemplos dentro de cada tipo de inovação, delimitados por sua natureza (incrementais ou radicais):

Quadro 7 - Exemplos de tipos de inovação (incremental e radical)

\begin{tabular}{|c|c|c|}
\hline “4 P” da Inovação & Incremental & Radical \\
\hline Inovação de Produto & $\begin{array}{l}\text { 1-Novas versões de modelos de carros já estabelecido. } \\
\text { 2-Lâmpadas incandescentes de melhor desempenho. }\end{array}$ & $\begin{array}{l}\text { 1-Toyota Prius - trazendo um novo conceito - motor } \\
\text { híbrido. } \\
\text { 2-Lâmpadas de LED, utilizando princípios } \\
\text { completamente diferentes e energeticamente } \\
\text { eficientes. }\end{array}$ \\
\hline Inovação de Processo & $\begin{array}{l}\text { 1-Serviços aprimorados de telefonia fixa. } \\
\text { 2-Ampliada gama de serviços de corretagem de ações. }\end{array}$ & $\begin{array}{l}\text { 1-Skype e outros sistemas de VolP. } \\
\text { 2-Compra e venda de ações online. }\end{array}$ \\
\hline Inovação de Posição & $\begin{array}{l}\text { 1-Hãagen-Dazs, ao mudar o foco de mercado de } \\
\text { sorvetes de crianças para adultos. } \\
\text { 2-Companhias aéreas, ao segmentar a oferta de } \\
\text { serviços para diferentes grupos de passageiros. }\end{array}$ & $\begin{array}{l}\text { 1-Abordar mercados subexplorados, por exemplo: Tata } \\
\text { Nano, carro focado no emergente. } \\
\text { 2-Companhias aéreas de baixo custo, que tornaram as } \\
\text { viagens aéreas acessíveis. }\end{array}$ \\
\hline Inovação de Paradigma & $\begin{array}{l}\text { 1-Dyson, ao redefinir o mercado de eletrodomésticos } \\
\text { em termos de produtos de engenharia de alta } \\
\text { performance. } \\
\text { 2-IBM, de fabricantes de máquinas de empresas de } \\
\text { serviços e soluções, vendendo sua ala de fabricação de } \\
\text { computadores e edificando a de consultoria e serviços. }\end{array}$ & $\begin{array}{l}\text { 1-Amazon, Google, Skype, redefinindo setores de } \\
\text { varejo, publicidade e telecomunicações por meio de } \\
\text { modelos online. } \\
\text { 2-Linux, Mozilla, Apache, ao passar usuários passivos a } \\
\text { comunidades ativas de usuários, criando em conjunto } \\
\text { novos produtos e serviços. }\end{array}$ \\
\hline
\end{tabular}

Fonte: Adaptado de Tidd e Bessant (2015). 


\subsubsection{Inovação aberta}

Além das tipologias de inovações citadas anteriormente, que podem ser executadas internamente às organizações, existe outra forma por meio da qual elas podem ser realizadas. Essa outra forma é o que se chama de inovação aberta, um tema que está sendo crescentemente explorado na literatura.

Segundo Chesbrough e Crowther (2006), a inovação aberta geralmente consiste em dois elementos-chave:

I O que chamam de outbound (de dentro para fora), que se refere a uma empresa que adota as suas tecnologias para comercializar externamente através de algumas formas não tradicionais.

II Segundo o inbound (de fora para dentro), que envolve a aquisição e alavancagem de insumos externos para o desenvolvimento de novas tecnologias internas.

Assim, de forma breve, o modo inbound pode ser definido como ideias ou tecnologias externas que são incorporadas internamente à organização, enquanto o modo outbound são ideias ou tecnologias internas que são usadas por outra organização, considerada mais preparada para desenvolver e comercializar essas ideias ou tecnologias (Chesbrough, 2003).

Exemplificando: no método inbound, a empresa engaja-se com uma série de parceiros externos para adquirir novas ideias e tecnologias (Baum, Calabrese \& Silverman, 2000; Lee, Park, Yoon \& Park, 2010). No método outbound, um startup pode desempenhar o papel de provedora de tecnologias para uma grande empresa, e tornando, assim, uma importante fonte de inovação (Audretsch, 1995).

Devido ao crescimento progressivo do interesse acadêmico em inovação aberta, essa também tornou-se, concomitantemente, uma prática disseminada nas organizações (Chesbrough, 2006). Assim, hoje, tanto na literatura quanto na visão dos executivos, a pesquisa nesse tema tem focado, na maioria das vezes, nas grandes empresas, mais do que nas pequenas e médias (Chesbrough \& Crowter, 2006; Van De Vrande et al., 2009; Lee et al., 2010; Ahn et al., 2015; 
Eftekhari \& Borges, 2015). E essa literatura existente destaca que a inovação aberta influencia positivamente a performance de uma organização (Dodgson et al., 2006; Gassmann et al., 2010).

Por isso, o foco desta pesquisa será na utilização da inovação aberta pelas grandes empresas, além de ter como enfoque o método inbound, que acontece quando as grandes empresas engajam-se com parceiros externos para adquirir ou tecnologias novas ou ideias novas, para, assim, dar início a um processo de inovação.

Com isso e de forma conclusiva, este trabalho irá utilizar as definições de inovações descritas no manual oficial de Oslo, última edição, do ano de 2005. A partir dessa referência, são definidos os quatro tipos de inovação, sendo eles de produto, processo, marketing e organizacional. E também, irá utilizar o conceito de inovação aberta como um dos modos que os quatro tipos de inovação podem ser executados. Por meio dessas definições, será possível definir parâmetros, para a construção das perguntas que serão feitas aos respondentes.

Em relação às métricas de inovação, por motivos já então listados anteriormente, não serão utilizados como base para a elaboração da metodologia desta pesquisa, por existirem grandes divergências na literatura e no próprio mundo corporativo de como mensurar-se uma inovação. Como não existe uma métrica estabelecida como padrão, ainda hoje, quando se trata de mensuração de inovações, os dados necessários para as construções de algumas fórmulas citadas neste trabalho, como as que necessitam de faturamento das empresas referentes à lançamento de novos produtos, por exemplo, não são de fácil acesso por meio das empresas, optando-se, assim, por sua não utilização.

\subsection{Inovação e o corporate foresight}

Como pôde ser verificado por meio da revisão da literatura, o campo da inovação cresceu bastante, de algumas décadas para cá, principalmente quando se leva em conta o seu resultado no contexto organizacional. Ao ser explicitado no tópico de corporate foresight, que informações futuras são muito importantes para o sucesso empresarial, surgem, assim, pesquisas que possuem como principal objetivo analisar, justamente, essa relação entre 
obtenção de informações futuras e inovação.

Porter e Millar (1985) analisam a competitividade das empresas no futuro, afirmando que a "revolução da informação", ou seja o acesso a informações importantes para projetar-se um futuro, afeta a concorrência de três formas vitais: primeiramente, alterando a estrutura da indústria, e ao fazê-lo, altera, também, as regras da concorrência; criando vantagens competitivas ao fornecer novas formas de superar seus rivais / concorrentes; e gerando negócios completamente novos, muitas vezes, dentro das operações já existentes de uma empresa.

Em relação ao processo do corporate foresight, Cunha, Palma e Costa (2006) veem a previsão menos como um processo técnico e analítico, mas mais como um processo humano permeado por uma dialética entre a necessidade de conhecer e o medo de conhecer. Assim, o corporate foresight tornou-se um termo predominantemente usado por muitas empresas para as suas atividades de estudos do futuro. Esse termo representa a análise das perspectivas de longo prazo de ambientes de negócio, mercado e novas tecnologias, e suas implicações específicas para as estratégias corporativas ligadas à inovação. Portanto, o corporate foresight pode ser entendido como uma orientação global para o futuro de uma organização e é considerado uma parte da gestão da inovação empresarial (Gruber \& Venter, 2006; Ruff, 2006).

Além disso, a excelência na gestão da inovação está cada vez mais ligada à capacidade de uma empresa estabelecer e fomentar os estudos do futuro (Heiko et al., 2010). O ex-presidente da Siemens, Von Pierer, gostava de enfatizar a seguinte frase: "A maneira mais certa de prever o futuro é criar e moldá-lo você mesmo". Consequentemente, o corporate foresight permite às empresas lidarem com mudanças radicais e internas / externas. Logo, considera-se a dinâmica da utilização das técnicas de estudos do futuro, algo complexo e que possui suas interdependências, sendo recomendado usar para fins mais adequados como decisões em matéria de gestão da inovação (Tessun, 2005).

Heiko et al. (2010) explicam que o corporate foresight é um excelente suporte de decisões, quando se trata de inovação. Segundo eles, de forma geral, existem duas maneiras distintas que o foresight pode contribuir e ajudar no processo de inovação, que são: antes de a ideia 
surgir, pois essa ferramenta auxilia de forma criativa a gerar, assim, novas ideias para futuras inovações, e segundo o foresight, também contribui para ideias ligadas à inovação, já então, pré-estabelecidas.

Van der Duin (2004) comenta que essa contribuição e integração entre o corporate foresight e a inovação pode acontecer em três níveis de intensidade, sendo eles:

I Integração ad hoc, que, segundo o autor, acontece quando os métodos de pesquisa do futuro e o processo de inovação são entidades separadas, que são combinadas ocasionalmente (exemplo: workshop);

II Método de integração, que acontece quando a pesquisa do futuro e o processo de inovação são estabelecidos por um desenvolvimento específico, baseado em um método integrado entre ambos (exemplo: desenvolver uma cadeia de inovação a partir da combinação da metodologia de cenários e um processo de inovação linear);

III E o terceiro nível é a integração completa que ocorre quando as duas variáveis estão completamente fundidas uma em outra (exemplo: metodologia de roadmaps que fornece informações sobre o futuro e mostra quais produtos ou serviços serão desenvolvidos no futuro).

Relacionado às aplicações do corporate foresight no contexto da inovação, Burmeister et al. (2004) comentam que existem cinco parâmetros de inovação que os estudos do futuro podem contribuir positivamente, sendo eles:

I A antecipação da procura futura;

II Uma maior qualidade do processo através de informações importantes;

III Orientação ao contexto inserido;

IV Construção de cronograma de inovação factível;

V Identificação de inovações estratégicas para o seu negócio.

A antecipação da procura futura gira em torno de analisar o que está por vir em um horizonte de longo prazo, sendo citado pelo autor que esse horizonte não é só de seis meses, mas também sendo importante olhar que irá acontecer entre cinco e dez anos. O segundo tópico 
entra na questão, quando o processo de inovação já existe, e o gestor ou a pessoa responsável pelo processo gostaria de obter mais informações para a sua melhor execução. O terceiro tópico, que trata sobre o contexto inserido, é entendido como o ambiente para onde a inovação destina-se, ou seja, se ela será executada dentro da empresa ou como um produto / serviço que será comercializado, para, assim, entender as variáveis desse contexto e medir se há propensão para inovação ou não. O quarto tópico é utilizar o corporate foresight para a construção de um cronograma de inovação factível, ou seja, entender qual seria o melhor momento para colocar a inovação em prática. E por último, o quinto traz a identificação de inovações estratégicas para o seu negócio, ou seja, utilizar alguma metodologia de prospecção para identificar inovações potenciais.

Um estudo empírico foi conduzido, no ano de 2006, na Europa, com 152 grandes empresas europeias, que possuía o principal objetivo de analisar quais eram os objetivos que as empresas conseguiam alcançar, quando utilizam metodologias de corporate foresight. Em relação aos resultados, $87,5 \%$ dos respondentes disseram que os estudos do futuro suportam decisões estratégicas em geral; 77,5\%, que ajuda a melhorar os planos empresariais de longo prazo; $65 \%$, possibilita prever uma série de alertas ruins antes mesmo que o problema ocorra; e 57,5\% consideram que o corporate foresight melhora o processo de inovação empresarial (Daheim \& Uerz, 2006).

Com esse foco em resultado, explicitado pelo número de 57,5\% das empresas europeias que acreditam no potencial inovador da utilização de métodos do futuro, Burmeister et al. (2002) acredita que o uso sistemático do corporate foresight na construção de um processo estratégico aumentam a probabilidade de que os investimentos realizados hoje resultem em inovação amanhã, sendo esse, um futuro próximo, em que haverá uma importância crescente dos métodos de construção de cenários, principalmente em inovações de produto.

Drew (2006) disserta sobre a aplicação do método de estudos de cenários para fomentar a inovação tecnológica empresarial. Segundo o autor, a técnica de cenários pode ser utilizada de forma bem-sucedida, quando se analisam inovações disruptivas, mas não só limitado a essa inovação, e sim, todos os tipos. E também, pode ser utilizada para estudar as mudanças que essas inovações podem causar na estrutura das indústrias e das empresas. 
Kaivo-oja (2006) estuda as relações existentes entre elementos do foresight com o sistema que envolve os processos de inovação. O autor coloca que a capacidade de pensar em termos em forças que não são óbvias e não podem ser medidas é um dos primeiros passos para moldarse o futuro. Assim, normalmente, a pesquisa prospectiva produz conhecimentos de tendências, opções de desenvolvimento e cenários, estando completamente ligada a tendências futuras de inovação.

Continuando nas citações referentes a aplicabilidades na inovação, Daheim, Neef, SchulzMontag e Steinmüller (2013) corroboram todos os autores citados anteriormente, dizendo que o corporate foresight está se tornando cada vez mais difundido, profissional e diversificado, e para essa metodologia de estudos do futuro ser bem-sucedida, ela deve ser integrada aos processos organizacionais como os que envolvem estratégia e inovação, para, assim, tornaremse mais visíveis. Pirttimäki (2006) acredita que a combinação de métodos de desenvolvimento de conceitos de produtos e serviços, juntamente com métodos de foresight, podem auxiliar o fomento de inovação; com isso, o corporate foresight pode ser utilizado tanto para o planejamento estratégico quanto para sua implementação.

Com o foco específico em planejamento estratégico, segundo Ruff (2006), os objetivos principais de uma estratégia lidada à inovação requerem uma detecção prévia de oportunidades e riscos. Uma avaliação orientada para ideias futuras de inovação segue cinco etapas sequencias: primeiramente, uma observação de tendências futuras, análise de impacto dessas tendências, geração de ideias e inovações, juntamente com a avaliação de sua viabilidade.

Seguindo nessa linha de pensamento, Schulz-Montag e Müller-Stoffels (2006) citam cinco etapas para um processo de inovação baseado em tendências e construção de cenários: análise de tendências, projeções de futuros relevantes que são os próprios cenários, geração de ideias inovadoras, avaliação de ideias e comunicação dessas ideias dentro da organização focando na transferência de conhecimento.

Referente aos tipos de inovação, Roveda e Vecchiato (2008) contribuem com a literatura, dizendo que workshops interativos e painel com especialistas podem se encaixar melhor como 
um apoiador de inovações incrementais, e técnicas de estudos de cenários e outras metodologias de estudos do futuro são mais apropriadas para olhar e fomentar inovações radicais. Em relação aos conceitos de cada tipo de inovação, o tópico sobre tipos de inovação explica todos esses exemplos citados pelo autor.

Segundo Fidler (2011) uma das finalidades claras dos estudos do futuro é a avaliação da evolução tecnológica; assim, nesse contexto de tecnologia em evolução, decisões necessitam ser tomadas e elas vão definir como a organização poderá fazer uso dela e obter resultados futuros. Além do mais, Von Reibnitzs (1988) explica que o corporate foresight possui várias funções, dentre elas prover insights para o desenvolvimento futuro do ambiente que a empresa encontra-se, e induzindo boas ideias para criação de novos produtos e serviços.

Em uma segunda perspectiva, o corporate foresight pode ajudar a enxergar a viabilidade tecnológica e comercial de algum processo de inovação ou até mesmo a não viabilidade, auxiliando, assim, o abandono inicial da ideia. Portanto, a grande questão trazida pelo autor é de que esse tipo de técnica prospectiva auxilia as organizações a lidar com grandes incertezas, prevenindo, assim, que invistam dinheiro, tempo e recursos em ideias que não se provem grandes sucessos no futuro.

Dror (1989) explica que o processo de desenvolvimento está intrinsicamente ligado ao processo de mudança tecnológica, que, por sua vez, está ligado às inovações realizadas por empresas. O campo aplicado da inovação é o contexto empresarial, que possui a grande preocupação de como manter-se inovador, comparativamente a outras empresas. Com isso, tende-se a levar o assunto da inovação para a questão da mensuração, com o enfoque de verificar se existem retornos do mesmo.

A questão que permeia a preocupação das empresas em se manterem inovadoras possui uma relação direta com o aumento de sua competitividade perante as demais. Segundo Adams, Bessant e Phelps (2006), uma quantidade considerável de literaturas tem sido acumulada ao longo do tempo, com o principal assunto abordado, sendo o tema da inovação, que é amplamente visto como uma forma de competitividade econômica (Porter \& Ketels, 2003). 
Portanto, a inovação focada no ambiente corporativo refere-se a mudanças planejadas nas atividades da própria empresa com uma visão em melhorar a sua performance (Mortensen \& Bloch, 2005). E como já comentado anteriormente, uma dentre as várias finalidades do estudo do futuro, trazida por Fidler (2011), é a avaliação da evolução tecnológica. Com isso, nesse contexto de tecnologia em evolução, decisões, precisam ser tomadas, e elas vão definir como a organização poderá fazer o seu uso, e assim, obter resultados futuros. Yoshida (2016) ainda complementa, dizendo que dessa maneira a prospecção do futuro tem um papel fundamental na estratégia tecnológica. Logo, pode-se concluir que existe um exemplo de integração entre o corporate foresight e a inovação.

Por isso e outros vários motivos, um contexto dinâmico e competitivo que as empresas permeiam hoje é necessariamente exigido, que sejam incorporados, em seus cotidianos, novos métodos e conceitos de gestão. Heiko et al. (2010) conclui, dizendo que com a utilização do corporate foresight, juntamente com a gestão da inovação, as empresas podem preparar-se para o aumento da concorrência de forma antecipada. Como já foi notado anteriormente, existem abordagens para implementar esses dois conceitos em diferentes contextos organizacionais. Contudo, é crucial que as empresas reflitam constantemente o seu status quo e identifiquem possíveis pontos de melhorias. Apenas as organizações que estão dentro dessa utilização bem-sucedida do corporate foresight como ferramenta de apoio à inovação estão bem preparadas para enfrentar os diversos desafios futuros.

\subsection{Modelo conceitual (design)}

A figura 2, a seguir, mostra o modelo conceitual teórico adotado nessa pesquisa. 
Figura 2 - Modelo conceitual teórico adotado nesta pesquisa

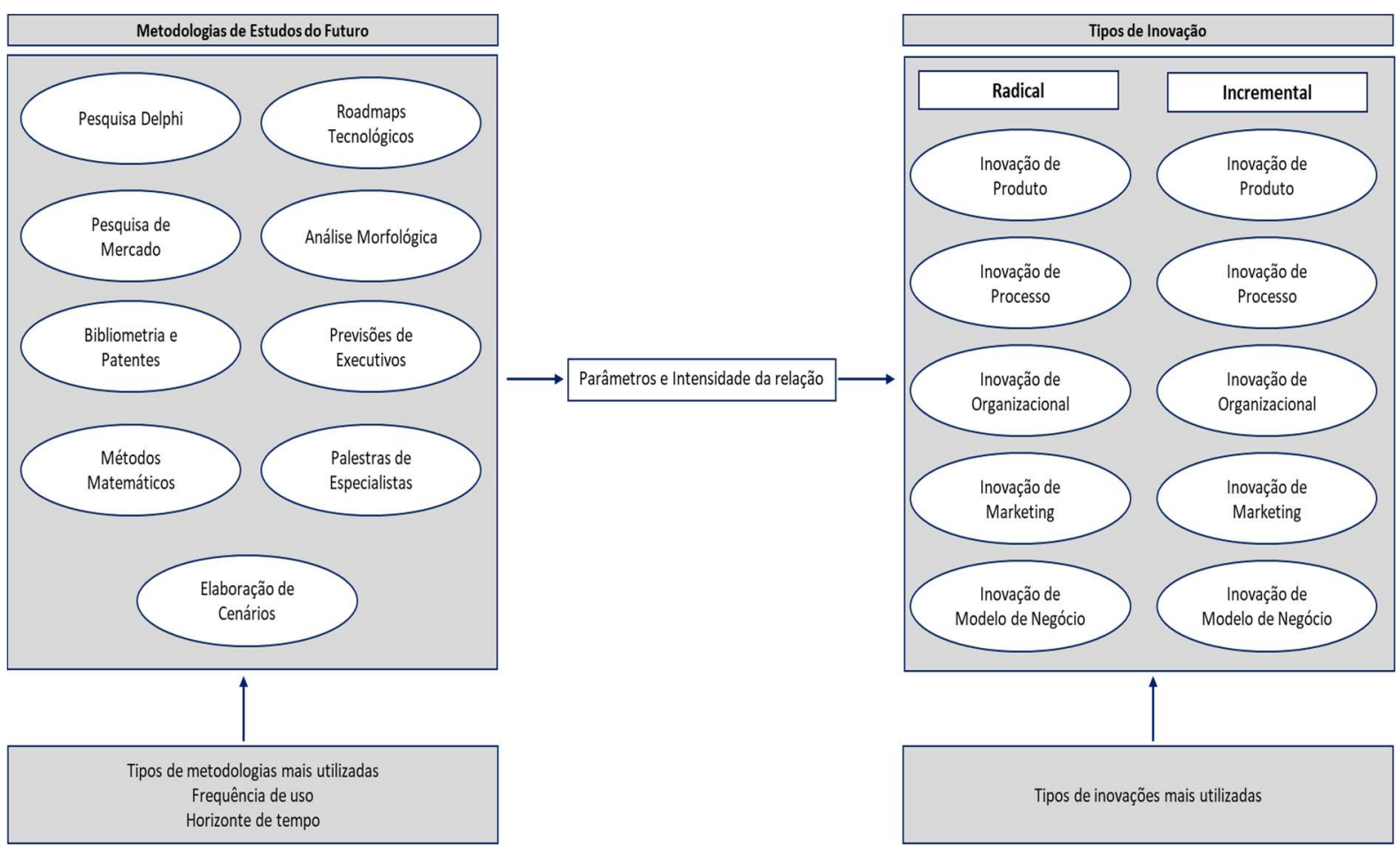

Fonte: a autora.

O modelo, acima, pode ser interpretado da seguinte maneira: na parte esquerda, são elencadas as metodologias de estudos do futuro, selecionadas, previamente, por meio da revisão da literatura. Essas metodologias são detalhadas, sem nenhuma divisão entre elas; por isso, no design do modelo elas encontram-se dentro da mesma caixa, que possui o título de "Metodologias de Estudos do Futuro".

Ainda referente à figura 2 (modelo conceitual), abaixo do bloco de metodologia de estudos do futuro, têm-se três tópicos que serão utilizados para o melhor entendimento da variável "estudos do futuro", que são: os tipos de metodologias mais utilizadas, frequência de uso de algum ou de todos os métodos, e o horizonte de tempo, em que é feito o uso de alguma dessas metodologias.

O segundo grande bloco à direita do modelo, é o bloco do "Tipos de Inovação", em que são classificados, desse modo, pelo manual de Oslo de 2005, sendo esse o seu último ano de divulgação. Internamente a esse bloco, são elencados quatro tipos de inovações: inovações de produto, processo, organizacional e de marketing. Além desses tipos, tem-se a inovação de 
modelo de negócio, conceito definido por Chesbrough (2010) como inovações que geram valor por meio de mudanças no modelo de negócio da empresa. Além dessa divisão, é feita uma nova subdivisão, por meio do conceito de natureza da inovação, dividindo em natureza radical e incremental.

E por fim, entre os dois grandes blocos, são definidos os dois pontos de partida para analisar se as metodologias de estudos do futuro apoiam o desenvolvimento do processo de inovação nas empresas. Esses pontos de partida são: os parâmetros de inovação e o grau de intensidade na relação entre as metodologias e os tipos de inovação.

Primeiramente, falando sobre o grau de intensidade, é possível identificar três níveis de integração entre as metodologias e os tipos de inovação, na literatura, sendo esses um nível mais fraco, chamado de ad hoc, um nível de integração médio, e um nível de integração total (Van der Duin, 2006). A partir desse conceito, será analisado qual o nível de integração entre as duas variáveis de pesquisa, nas empresas respondentes, podendo, assim, tirarem-se conclusões sobre a intensidade do uso das metodologias de estudos do futuro e dos processos de inovação em conjunto. O principal objetivo desse ponto de partida é analisar graus de associações entre a variável dependente e independente do estudo.

O segundo ponto de partida são os parâmetros de inovação; segundo Burmeister et al. (2004), existem cinco formas diferentes em que as metodologias de estudos do futuro podem atuar como suporte ao processo de inovação, sendo elas: a antecipação da procura futura, uma maior qualidade do processo através de informações importantes; orientação ao contexto inserido; construção de cronograma de inovação factível; e identificação de inovações estratégicas para o seu negócio. Com isso, além de analisar o grau de intensidade da relação, será analisado em qual parâmetro o apoio das metodologias é feito de forma mais intensiva.

Para tornar-se mais claro o conceito proposto pelo modelo conceitual da pesquisa, cabe lembrar que é utilizada a diretriz teórica de que as metodologias de estudos do futuro são recomendadas como uma forma de apoio ao processo de inovação. Pode-se notar essa questão por meio da revisão da literatura que traz uma série de pesquisas empíricas que já relacionam essas duas grandes variáveis dessa pesquisa. 
A literatura traz indícios de que a relação entre essas duas variáveis do estudo é válida; com isso, faz-se necessário investigar e analisar essa relação, por meio de uma pesquisa com os gestores de empresas brasileiras, para verificar a assertividade da mesma. Além de analisar de que forma esse apoio ocorre.

A partir do modelo conceitual teórico da pesquisa, pode-se detalhar a integração entre objetivos, questões de pesquisa, referencial teórico e a metodologia utilizada. A representação dessa integração visa à consistência metodológica e é baseada na técnica chamada de "Matriz de Amarração" de Mazzon. O principal objetivo dessa matriz é avaliar a coerência das relações estabelecidas entre as dimensões e decisões de encaminhamento de pesquisa, e assim indicar a consistência metodológica da intervenção científica (Telles, 2001).

Na figura 3, pode-se visualizar a matriz de amarração da presente pesquisa, onde, na primeira coluna, é inserido o modelo conceitual teórico, de forma resumida. Na segunda coluna, estão os objetivos específicos, que foram citados na introdução da pesquisa; em seguida, na terceira coluna, as questões de pesquisa, que se relacionam, diretamente, com os três objetivos específicos. E por último, as técnicas de análise que são elencadas de forma específica para cada questão de pesquisa. 


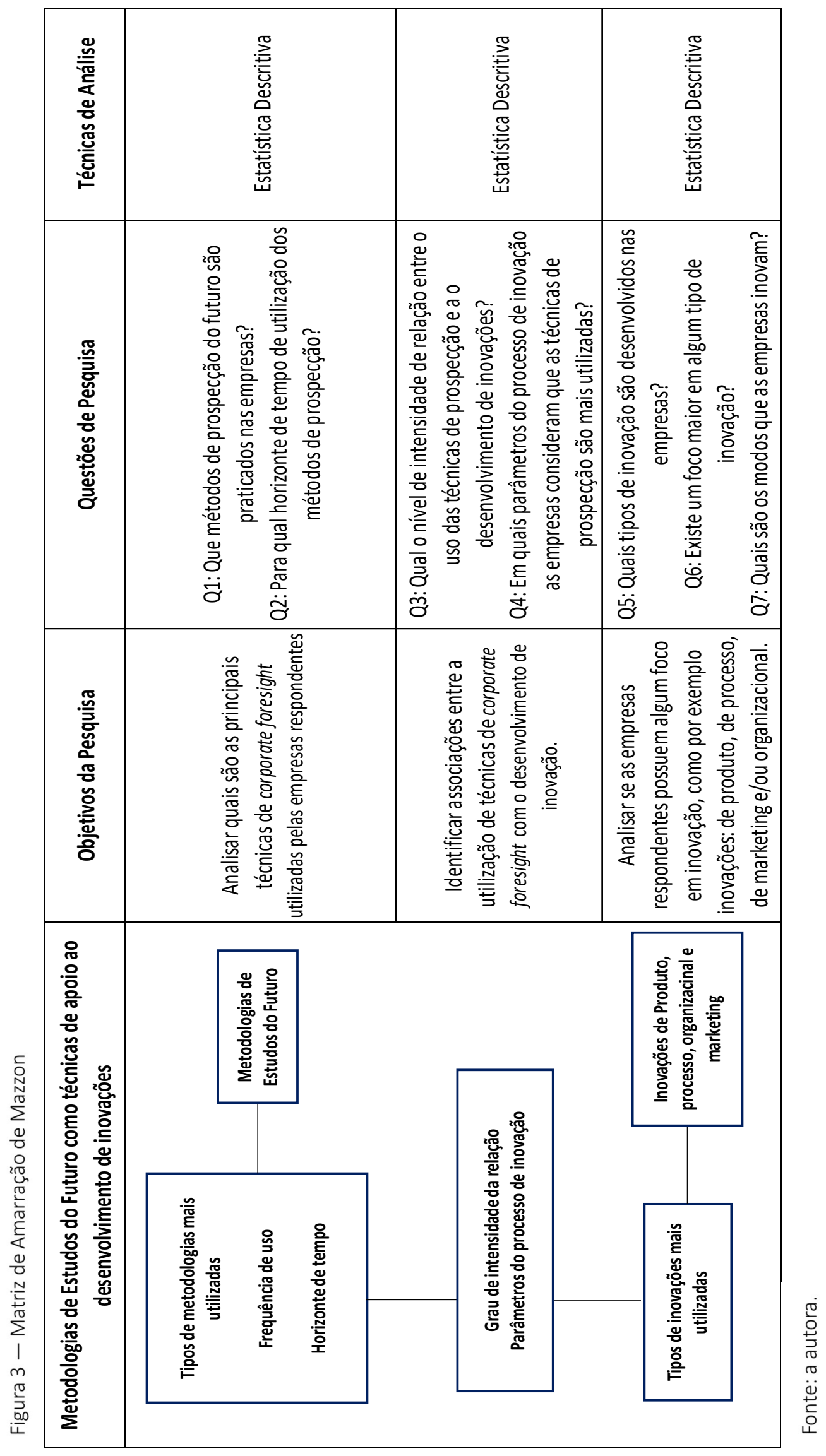




\section{METODOLOGIA}

Esta seção descreve as principais características que permeiam a etapa de metodologia deste trabalho, sendo elas: a natureza e o método de pesquisa utilizados, as variáveis e indicadores definidos, o modelo conceitual da pesquisa, universo e amostra, matriz de amarração, técnicas utilizadas para a análise de dados, e por fim, as limitações metodológicas do estudo.

\subsection{Natureza e método de pesquisa}

É de suma importância que se estabeleça um objetivo claro de pesquisa, para, assim, definir, de maneira coerente, o método a ser utilizado. A proposta desta pesquisa é analisar como a utilização de metodologias de Corporate Foresight, pelas empresas, apoia o desenvolvimento do processo de inovações de produto, processo, organizacional, marketing e negócio. As metodologias de estudos do futuro e o escopo de processos de inovação foram definidos por meio de uma extensa revisão bibliográfica, já então explicitados no tópico anterior.

A partir desse objetivo de pesquisa, também é possível delimitar uma pergunta problema: o Corporate Foresight é útil para apoiar o desenvolvimento do processo de inovação nas empresas? Tendo em vista essa pergunta de pesquisa e o objetivo delimitado, o estudo é caracterizado como de natureza quantitativa, uma vez que as relações entre as variáveis são analisadas por meio de medições numéricas, contagem e uso de estatísticas, com vistas a identificar e entender padrões.

Segundo Sampieri et al. (2006), as pesquisas qualitativas "utilizam coleta de dados sem medição numérica para descobrir ou aperfeiçoar questões de pesquisa e podem ou não provar hipóteses em seu processo de interpretação". Já, o enfoque quantitativo é definido como aquele que "usa coleta de dados para testar hipóteses, com base na medição numérica e na análise estatística, para estabelecer padrões de comportamento". É importante citar que essa pesquisa não irá testar hipóteses, e sim, analisar, de forma descritiva, os dados coletados.

Em relação aos tipos de estudos utilizados em pesquisas, Sampieri (2006) define como existentes: estudos exploratórios, descritivos, correlacionais e explicativos. Segundo esse autor, 
os estudos explicativos possuem como objetivo, além da descrição de conceitos, fenômenos ou estabelecimento de relações, também analisar e responder as causas dos acontecimentos, fatos, fenômenos físicos ou sociais (Sampieri, 2006). Essa definição não pode ser considerada como o método desta pesquisa, pois não é apresentado como foco estudar as causas de acontecimentos específicos.

Sampieri (2006) explica que os estudos correlacionais pretendem responder questões de pesquisa que possuem o enfoque de analisar correlações entre variáveis, ou seja, avaliar a relação entre dois ou mais conceitos, categoriais ou variáveis em estudo. Essa pesquisa também não pode ser classificada como correlacional.

Já os estudos exploratórios possuem o objetivo de examinar um tema ou um problema de pesquisa pouco estudado, para o qual tem-se muitas dúvidas, ou não foram abordados anteriormente. Sendo assim, esse estudo caracteriza-se, primeiramente, como exploratório, por tratar de um tema, corporate foresight e a inovação empresarial, com poucos estudos publicados.

Por último, um estudo descritivo possui como objetivo descrever situações, acontecimentos e feitos com o intuito de explicar como se manifesta determinado fenômeno (Sampieri, 2006). Esta pesquisa também pode ser definida como descritiva, por possuir uma característica de descrever, como se dá o relacionamento entre as duas principais variáveis do estudo, trazendo, como técnica de análise, métodos correlacionais para chegar-se a esse objetivo.

Sendo assim, o presente estudo possui a característica quantitativa exploratória-descritiva, que, de acordo com Sampieri (2006), mede o grau de relação entre duas ou mais variáveis (quantificam as relações), ou seja, medem cada variável presumidamente relacionada, e depois, também, medem e analisam a correlação. Essas correlações podem ser expostas em forma de questões que serão testadas e respondidas após a aplicação da pesquisa.

\subsection{Definição de variáveis}

Segundo Cooper e Schindler (2016), variáveis podem ser definidas como um símbolo de um 
evento, ato, característica, traço ou um atributo, que pode ser mensurado e a que pode ser atribuído um valor numérico. Como explicitado acima, o caráter do estudo é exploratóriodescritivo, ou seja, não é possível inferir dependência prévia entre as variáveis. Assim, a definição das variáveis é dividida em dois parâmetros: variáveis quantitativas (discretas ou contínuas) e variáveis qualitativas (nominais ou ordinais).

Segundo Bussab e Morettin (2010), uma variável qualitativa apresenta, como possíveis realizações, uma qualidade (ou atributo) do indivíduo pesquisado, enquanto as variáveis quantitativas apresentam, como possíveis realizações, números resultantes de uma contagem ou mensuração.

Além disso, existem suas subclassificações. No campo das qualitativas, pode-se fazer uma distinção entre dois tipos diferentes: nominais, para qual não existe nenhuma ordenação nas possíveis realizações, e ordinais, para as quais existe uma ordem nos resultados.

Do mesmo modo, as variáveis quantitativas possuem dois tipos distintos de classificações: discretas, um conjunto finito ou enumerável de números, e que resultam, frequentemente de uma contagem, e as contínuas, que são classificadas como possíveis valores que pertencem a um intervalo de número reais e que resultam de uma mensuração (Bussab \& Morettin, 2010).

Variáveis ligadas ao perfil dos respondentes: No questionário aplicado encontram-se três variáveis que caracterizam o perfil dos respondentes da pesquisa: cargo na atual empresa, formação (grau de escolaridade), e tempo de experiência profissional.

Cargo na atual empresa pode ser classificada como uma variável qualitativa ordinal, primeiramente qualitativa, pois descreve uma qualidade / atributo do indivíduo, e ordinal, por seguir uma ordem, de menor grau de formação para maior grau de formação. Em seguida, grau de escolaridade é considerada, também, uma variável qualitativa ordinal, pelos mesmos motivos citados.

E por fim, tempo de experiência considera-se como uma variável quantitativa discreta, por ser um conjunto de número resultantes de uma mensuração e que possui número finito / 
enumerável de tempo. Essas três variáveis foram selecionadas com o objetivo de ter-se o conhecimento do grau de senioridade dos respondentes

Variáveis ligadas ao perfil das empresas: Em relação à categoria de perfil das empresas em que os respondentes trabalham, foram utilizadas: forma de controle da empresa, origem do capital, faturamento, e setor de atuação.

Forma de controle da empresa é considerada uma variável qualitativa nominal, por não exercer nenhum tipo de análise de ordem; em seguida, origem do capital classifica-se também como qualitativa nominal; faturamento da empresa distingue-se das anteriores por ser quantitativa discreta, por mensurar um número finito de observações, dado que, no questionário, foram limitados os valores possíveis de faturamento. E por fim, o setor de atuação da empresa, como uma variável qualitativa nominal, com o intuito de caracterizar o campo de trabalho de cada uma das empresas.

Ademais, outras variáveis são utilizadas no questionário com o principal intuito de descrever o modelo conceitual da pesquisa. Dentre elas encontra-se: tipo de métodos de prospecção, tipos de inovação, horizonte de tempo dos métodos de prospecção, modos de executar a inovação nas empresas, intensidade da relação entre os métodos prospectivos e os tipos de inovação, parâmetros de inovação, e por fim, grau de satisfação da relação da utilização dos métodos de prospecção e a execução do processo de inovação.

Métodos prospectivos: Delphi; elaboração de cenários; roadmaps tecnológicos; análises bibliométrica e patentes; análise morfológica; métodos matemáticos; palestras de especialistas; pesquisa de mercado; previsões e projeções de executivos, força de vendas e distribuidores. Todas essas técnicas elencadas já foram embasadas, no tópico referente à revisão teórica.

Essas variáveis são consideradas como qualitativas nominais e a forma de tratamento desses dados será feita da seguinte forma: será perguntado aos respondentes se a empresa utiliza alguma dessas técnicas dentro de seu contexto específico, podendo ser respondido pelo entrevistado qualquer um desses métodos elencados e caso a resposta seja sim, em alguma 
das opções, será contato o número de respondentes que faz uso de cada uma dessas técnicas.

Tipos de inovação: são divididas em inovações de produto, processo, organizacional, de marketing e de negócio. Essas cinco tipologias podem fazer parte de duas naturezas ou dimensões diferentes, sendo elas: radical ou incremental. O intuito dessa divisão é ter uma análise mais detalhada do estudo, já que algumas empresas não possuem características de serem inovadoras radicais, até mesmo por conta de seu setor de atuação.

A natureza de cada tipo de inovação é explicada por Neely e Hii (1998), que não incluem o conceito de inovação de marketing, por esse ser um conceito mais recente de inovação, sendo explicado apenas no manual de Oslo de 2005. Segundo os autores, a inovação também pode ser classificada de acordo com a sua natureza, sendo elas: radical e incremental.

O conceito dessas naturezas é dado por meio de exemplos: radical seria um lançamento de uma nova vacina ou microprocessador, ou seja, algo que não existe no formato que está sendo criado é considerado como uma inovação radical. A inovação incremental pode ser exemplificada como a introdução de um chip com uma capacidade maior do que um já existente, ou seja, torna-se incremental quando você incrementa, torna melhor um produto ou serviço já existente. Sendo assim, esse conceito é válido para qualquer tipo de inovação que irá ser tratada nessa pesquisa (produto, processo, organizacional, marketing e negócios).

O tratamento desse dado será feito, também, por meio de perguntas fechadas inseridas em um questionário estruturado, que trarão questionamentos diretamente relacionados às questões de pesquisa deste estudo, com o intuito final de responder à pergunta-problema de pesquisa.

Horizonte de tempo: variável qualitativa ordinal (define uma ordem no tempo de utilização de cada método prospectivo), além disso, está dividida em sete intervalos distintos de tempo.

Modos de inovar: variável qualitativa nominal, sendo dividida em três modos distintos de inovar, sendo eles: de forma descentralizada, centralizada e por meio de inovação aberta. 
Intensidade de inovação: variável qualitativa nominal, com cinco níveis de intensidade diferente e três marcos: ad hoc, método de integração e integração completa.

Parâmetros de apoio à inovação: variável qualitativa nominal, com cinco tipo de parâmetros distintos, que caracterizam em qual momento do processo de inovação, os métodos prospectivos apoiam de forma significativa, sendo eles: na antecipação da procura futura de alguma ideia inovadora; aumenta a qualidade do processo de inovação, através das informações importantes coletadas; orientação ao contexto no qual ela será inserida; construção de cronograma de implementação factível da inovação estudada, e identificação de inovações estratégicas para o seu negócio.

Grau de satisfação: variável qualitativa ordinal; possui sete graus de satisfação diferentes, em ordem do pior para o melhor. Essa variável visa a analisar o grau de satisfação dos respondentes em relação ao apoio oferecido pelos métodos prospectivos, no momento em que a empresa pretende inovar.

\subsection{Universo e amostra}

O foco desta pesquisa, ou também chamado de população da pesquisa, são as empresas que atuam no Brasil, com origem de capital nacional ou estrangeiro, independentemente do tamanho ou setor de atuação. Segundo Cooper e Schindler (2016), população é a coleção total de elementos sobre os quais, nós, pesquisadores, queremos fazer algumas inferências. Porém, por questões de custos, melhor precisão dos resultados, velocidade de coleta de dados e disponibilidade de se atingir toda a população, faz-se necessário usar o conceito de amostragem.

Conceitualmente falando, uma amostra representa um subgrupo da população, sendo, assim, um subconjunto de elementos que pertencem a esse conjunto (Sampieri et al., 2006), e que também representam as características da população. Assim, a ideia básica da amostragem é que, selecionando alguns elementos da população, pode-se desenhar conclusões sobre toda a população da pesquisa. Assim, um elemento da população é um participante individual ou um objetivo no qual a mensuração é feita (Cooper \& Schindler, 2016). 
Portanto, relacionada à definição da amostra de pesquisa, dada a inviabilidade de atingir-se toda a população, optou-se por utilizar uma amostragem não-probabilística, que, segundo Sampieri et al. (2006), é definida como "subgrupo da população no qual a escolha dos elementos não depende da probabilidade, e sim, das características da pesquisa". No caso desta pesquisa, é utilizada a amostra não-probabilística, justamente pelo fato de ter-se uma base de potenciais respondentes que possuem as características-alvo da população.

Previamente à aplicação oficial da pesquisa, foi realizado um pré-teste com cinco pessoas de características similares aos respondentes-alvo da pesquisa para testar a clareza das perguntas, com o intuito de atingir de forma efetiva o objetivo das mesmas. Adicionalmente, durante a aplicação da pesquisa foram realizados quatro folllow-ups por e-mail, com o objetivo de conseguir o maior número de respostas possível e conscientizar os participantes da importância em se responder o questionário.

O convite realizado aos respondentes para participarem da pesquisa foi enviado via Internet, mais especificamente por e-mail, com o link referente ao questionário a ser preenchido. Esse convite foi feito a toda base-alvo da pesquisa, que é uma base de respondentes que pertence ao PROFUTURO (Programa de Estudos do Futuro), grupo de pesquisa que auxilia empresas e instituições públicas e privadas a aprimorar seus processos de planejamento, por meio de realização de estudos e pesquisas. No caso desta pesquisa, o universo é composto pelas empresas cujos respondentes são profissionais, atuam em cargos relacionados à responsabilidade de gestão, como, por exemplo, supervisores, gerentes, superintendentes, diretores, presidentes e proprietários.

A amostra de respondentes utilizada nesta pesquisa é formada por alunos e ex-alunos de cursos de pós-graduação em administração do PROFUTURO. As razões por esta escolha são:

I Os indivíduos contidos na amostra apresentam o tipo característico desejado para a coleta de dados, ou seja, são gestores de empresas atuantes no Brasil;

II São disponíveis os contatos de e-mail pessoal e profissional de cada indivíduo;

III A autora desta pesquisa pertence ao grupo de pesquisa do PROFUTURO, aumentando o 
potencial de atuação sobre a taxa de resposta ao instrumento de coleta.

A pesquisa foi encaminhada para 1.010 pessoas que trabalham atualmente em empresas que atuam no Brasil, de capital nacional ou estrangeiro, de diferentes portes e também setores de atuação.

Essas empresas serão classificadas por seu porte, de acordo com o seu faturamento líquido. Sendo assim, segundo a base de dados do balanço da Serasa Experian de 2017, as categorias são as seguintes:

I Small: faturamento líquido $\leq 250$ mil reais;

II Small Plus: faturamento líquido 250 mil $\geq 4$ milhões;

III Middle: faturamento líquido 4 milhões $\geq 25$ milhões;

IV Middle Plus: faturamento líquido 25 milhões $\geq 50$ milhões;

V Corporate: faturamento líquido 50 milhões $\geq 200$ milhões;

VI Corporate Plus: faturamento $\geq 200$ milhões.

Por fim, o instrumento de pesquisa consiste de um questionário com perguntas estruturadas, que são divididas em três blocos. O primeiro bloco trata de perguntas referentes a informações de inovação e foresight das empresas, totalizando nove perguntas. O segundo bloco é composto de cinco perguntas, referentes a características do respondente. E por último, sete perguntas sobre informações da empresa em que o respondente trabalha. O questionário encontra-se no apêndice deste trabalho, para fins de consulta.

\subsection{Abordagem metodológica do estudo}

A análise de dados é feita por meio de estatística descritiva.

A estatística descritiva é um conjunto de técnicas que permite, de forma sistemática, organizar, descrever, analisar e interpretar dados de estudos qualitativos e quantitativos. O objetivo de se utilizar a estatística descritiva é pelo motivo desse estudo possuir um caráter exploratóriodescritivo, e que, segundo Bussab e Morettin (2010), essa metodologia visa justamente a uma 
análise exploratória de dados.

Assim, essa abordagem será utilizada para obter dos dados a maior quantidade possível de informações, primeiramente por meio de medidas de posição, ou seja, valores que sejam representativos da série inteira. As medidas mais utilizadas foram as empregadas nesse estudo: média, mediana e moda.

Segundo Bussab e Morettin (2010), a moda pode ser definida como a realização mais frequente do conjunto de valores observados, a mediana é a realização que ocupa a posição central da série de observações, quando essas estão ordenadas em ordem crescente. E por fim, média aritmética é a soma das observações dividida pelo número delas. Com o objetivo de melhor entendimento dos dados, os resultados, além de serem mostrados por meio de resumos numéricos, também são exibidos por meio de técnicas gráficas.

Além das medidas de posição, foi utilizada a análise bidimensional, que tem como principal objetivo analisar a situação estudada e explorar as relações entre as colunas, ou até mesmo entre as linhas. Essa ferramenta de análise conjunta é considerada poderosa para a compreensão do comportamento dos dados. Assim, serão utilizadas tabelas de dupla entrada, consideradas adequadas para variáveis qualitativas, onde aparecerão as frequências absolutas dos dados que pertencem simultaneamente nas duas categorias.

Portanto, o principal objetivo da utilização das medidas de posição juntamente com a análise bidimensional é encontrar as possíveis relações e/ou associações entre as duas variáveis estudadas, métodos prospectivos e inovação. 


\section{APRESENTAÇÃO E ANÁLISE DOS RESULTADOS}

Considerando a amostra de 1.010 respondentes da pesquisa quantitativa, obtivemos um total de 293 visualizações, sendo que desses, 187 iniciaram o questionário, e 68 concluíram seu preenchimento. Entende-se que a pesquisa, por possuir um foco bastante específico de respondentes, o número atingido é satisfatório. Foi realizado um follow-up individualizado com alguns dos respondentes, para termos respostas consistentes, e de pessoas que possuem o perfil alvo dessa pesquisa.

A análise dos resultados será feita por meio de técnicas de análise estatística descritiva, com o principal intuito de explorar os dados coletados. Segundo Larson e Farber (2010), a estatística descritiva tem como objetivo tornar os dados mais fáceis de serem entendidos, descrevendo tendências, médias e variações, ou seja, uma maneira de identificar padrões que auxiliam no entendimento do assunto pesquisado.

\subsection{Qualificação da amostra}

A primeira fase da apresentação dos resultados será composta pelas características que compõem a amostra de pesquisa, sendo dividida em duas classes: perfil dos respondentes, que irá tratar sobre nível de experiência acadêmica e profissional da amostra, além de grau de senioridade. Do ponto de vista das empresas, serão analisados setor de atuação, origem do capital (brasileiro ou estrangeiro), forma de controle e o faturamento (parâmetro para se medir o porte).

\subsubsection{Perfil dos respondentes}

A maioria dos respondentes possui cargos de gerente, diretor ou presidente totalizando $85 \%$ dos respondentes, com tempo de experiência entre 16 e mais de 20 anos (85\%) e formação acadêmica com pós-graduação lato sensu ou stricto sensu (99\%). Por meio dessa informação, é possível chegar à conclusão de que os respondentes dessa pesquisa possuem cargos sêniores em suas respectivas empresas. 
A tabela 1 mostra a distribuição dos respondentes por cargo:

Tabela 1 - Distribuição dos respondentes por cargos

\begin{tabular}{ccc}
\hline Cargo & Frequência & Porcentagem \\
\hline Gerente & 25 & $37,88 \%$ \\
Diretor & 20 & $30,30 \%$ \\
Presidente & 11 & $16,67 \%$ \\
Analista & 4 & $6,06 \%$ \\
Supervisor & 3 & $4,55 \%$ \\
Consultor & 3 & $4,55 \%$ \\
\hline
\end{tabular}

Fonte: a autora.

Além de a maioria dos respondentes fazer parte de um grupo de cargos executivos, $85 \%$ desses possuem mais de 16 anos de experiência profissional, representando um grupo bastante experiente. Essa senioridade dos respondentes é bastante importante para a pesquisa, pois os temas tratados tendem a concentrar-se nos altos cargos das empresas. A tabela 2 evidencia essa informação, em ordem decrescente de frequência:

\begin{tabular}{|c|c|c|}
\hline Tempo de experiência & Frequência & Porcentagem \\
\hline Mais de 20 anos & 41 & $61,19 \%$ \\
\hline 16 a 20 anos & 16 & $23,88 \%$ \\
\hline 11 a 15 anos & 6 & $8,96 \%$ \\
\hline 6 a 10 anos & 3 & $4,48 \%$ \\
\hline 2 a 5 anos & 1 & $1,49 \%$ \\
\hline
\end{tabular}

Fonte: a autora.

E para complementar a alta experiência de mercado, a maioria dos respondentes possui um elevado grau de formação acadêmica: 99\% possuem, além do ensino superior, algum tipo de pós-graduação, sendo $78 \%$, lato sensu, e $21 \%$, stricto sensu. A tabela 3 possui a frequência dessa informação em ordem decrescente de frequência:

Tabela 3 - Distribuição dos respondentes por formação acadêmica

\begin{tabular}{ccc}
\hline Formação & Frequência & Porcentagem \\
\hline Lato Sensu & 52 & $77,61 \%$ \\
Stricto Sensu & 14 & $20,90 \%$ \\
Graduação & 1 & $1,49 \%$ \\
\hline
\end{tabular}

Fonte: a autora. 


\subsubsection{Perfil das empresas}

Em relação ao perfil das empresas, a amostra caracteriza-se por uma grande diversidade de setores, contribuindo positivamente para a abrangência da pesquisa. A maioria das empresas possui uma origem de capital brasileira (61\%), como mostrado no gráfico 1.

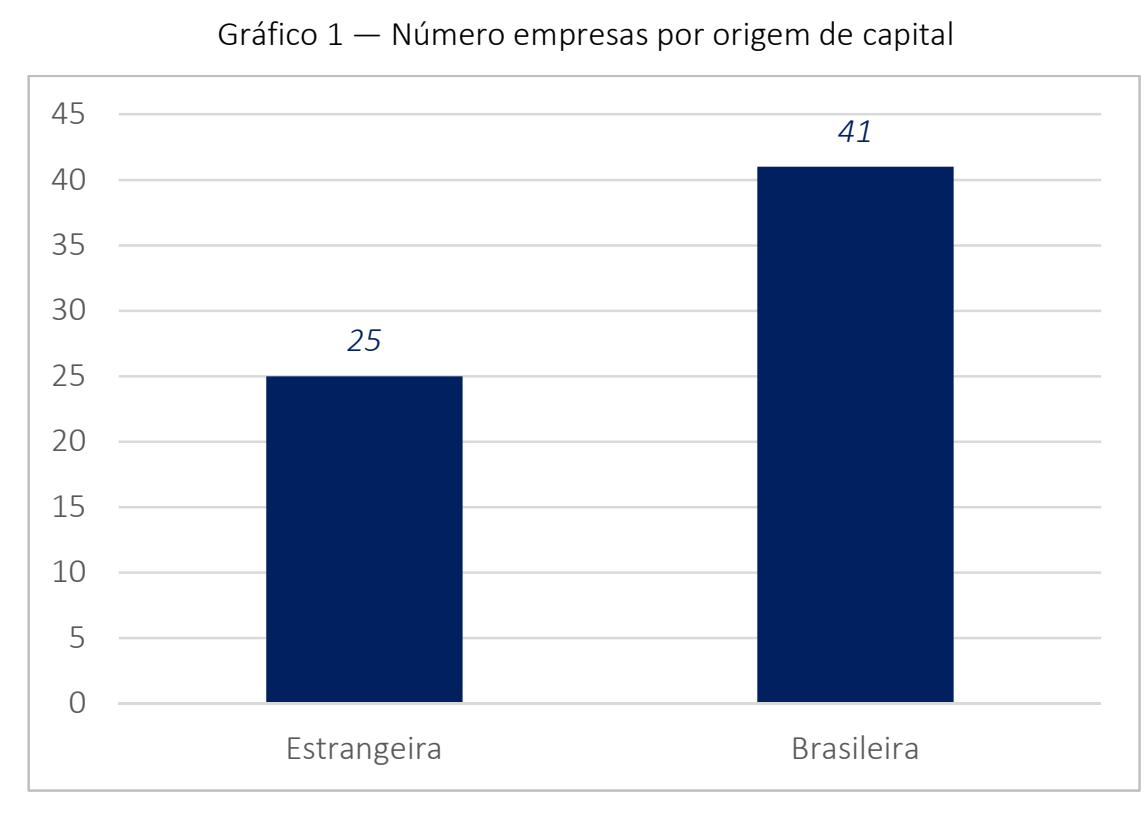

Fonte: a autora.

Além do mais, a forma de controle predominante é limitada (31\%), seguida de capital aberto (25\%) e capital fechado (24\%). Segue, a seguir, o gráfico 2, que mostra essa distribuição em ordem crescente dos dados: 
Gráfico 2 - Número de empresas por forma de controle

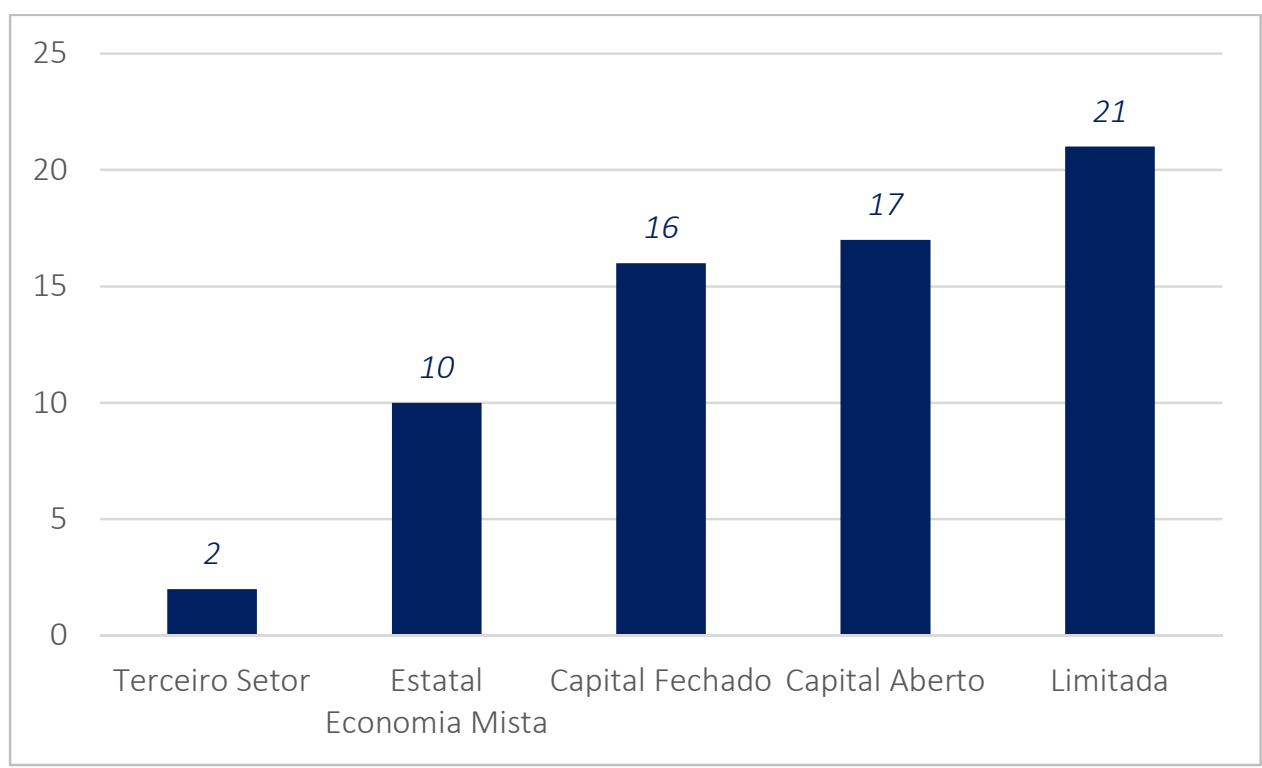

Fonte: a autora.

Em relação ao porte das empresas, a classificação é realizada por meio do faturamento líquido, de acordo com a classificação da Serasa Experian de 2017, empresa que delimita os seguintes grupos:

I Small: faturamento líquido $\leq 250$ mil reais;

II Small Plus: faturamento líquido 250 mil $\geq 4$ milhões;

III Middle: faturamento líquido 4 milhões $\geq 25$ milhões;

IV Middle Plus: faturamento líquido 25 milhões $\geq 50$ milhões;

V Corporate: faturamento líquido 50 milhões $\geq 200$ milhões;

VI Corporate Plus: faturamento $\geq 200$ milhões.

Assim, analisando os faturamentos indicados no questionário quantitativo, $73 \%$ dos respondentes trabalham em empresas do segmento corporate, que é considerado o segmento de maior porte do mercado. Esse segmento é dividido, ainda, em duas subcategorias: Corporate (faturamento líquido entre 50 milhões e 200 milhões), sendo 15,15\% da amostra; e Corporate Plus (mais de 200 milhões em faturamento líquido), sendo essa última categoria 58\% da amostra. Segue o gráfico 3, que mostra esses valores, em ordem de categoria de faturamento. 
Gráfico 3 - Número de empresas por faturamento

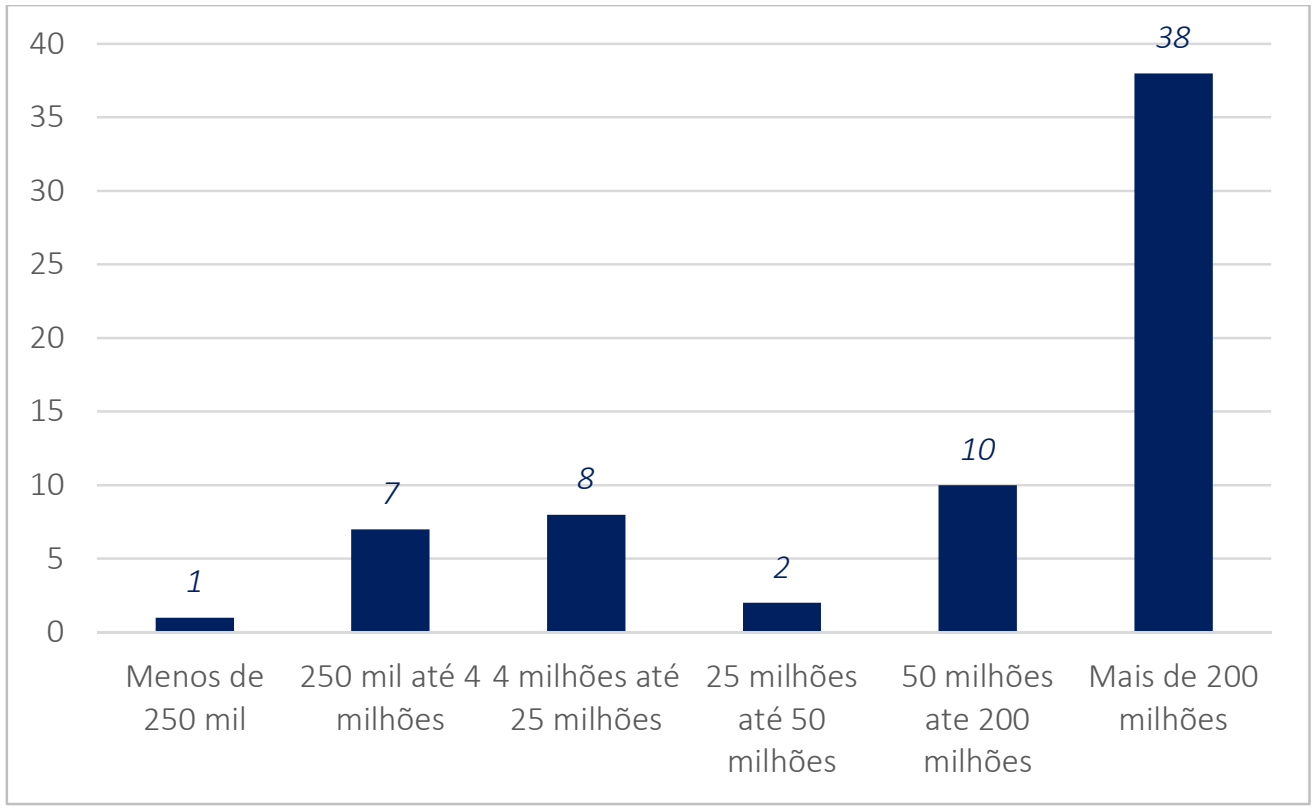

Fonte: a autora.

Por fim, no quesito perfil das empresas, tem-se o setor que elas atuam. De acordo com a distribuição obtida, pode-se observar que não houve um padrão de setor, ou seja, os dados foram bastante distribuídos, porém dois setores ficaram com uma concentração maior, sendo eles: Financeiro, em primeiro lugar, com 13 empresas, e Tecnologia da Informação, em segundo, com 8 empresas. Segue o gráfico 4, com os respectivos resultados, em ordem crescente de valores: 
Gráfico 4 - Número de empresas por setor de atuação

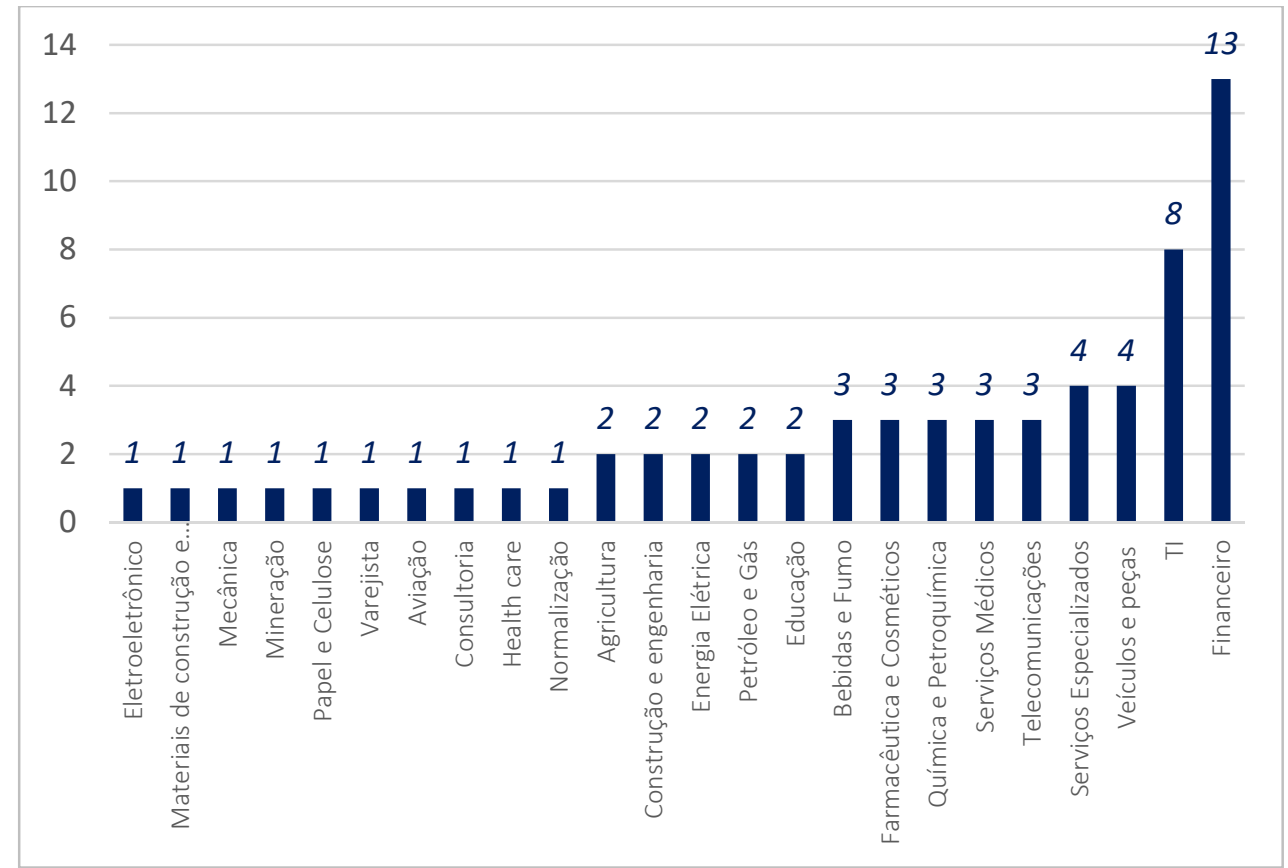

Fonte: a autora.

\subsection{Corporate foresight}

Este tópico apresenta as principais técnicas de corporate foresight utilizadas pelas empresas, e para qual horizonte de tempo elas são utilizadas.

\subsubsection{Principais técnicas de corporate foresight}

Na questão número 1 do questionário, foi perguntado aos respondentes quais eram os métodos de prospecção praticados em sua atual empresa.

Na tabela 4, a seguir, as informações estão organizadas em ordem decrescente de frequência, lembrando que cada respondente poderia solicitar um método ou mais que a sua empresa utiliza.

O total de marcações de métodos prospectivos foi de 214 , dado que era permitido marcar mais de uma opção, cada respondente indicou em média 3 tipos diferentes de métodos utilizados 
por sua empresa.

Tabela 4 - Frequência de métodos de prospecção

\begin{tabular}{lcc}
\hline \multicolumn{1}{c}{ Método de Prospecção } & Frequência & $\%$ (100\% - 68) \\
\hline Pesquisa de mercado & 46 & $67,65 \%$ \\
Cenários & 44 & $64,71 \%$ \\
Prev. e proj. de executivos, força de vendas e distribuidores & 39 & $57,35 \%$ \\
Palestras com especialistas & 35 & $51,47 \%$ \\
Roadmaps & 22 & $32,35 \%$ \\
Métodos matemáticos & 16 & $23,53 \%$ \\
Delphi & 7 & $10,29 \%$ \\
Bibliometria e patentes & 4 & $5,88 \%$ \\
Análise morfológica & 1 & $1,47 \%$ \\
\hline
\end{tabular}

Fonte: a autora.

Nota-se, na tabela 4, que os métodos mais utilizados foram: Pesquisa de mercado, com 67,6\% dos respondentes, indicando que suas empresas fazem elevada prática desse método, seguido de Cenário, com 64,7\%, Previsões e projeções de executivos e forças de vendas e distribuidores, em terceiro, com 57,4\%, e em quarto, com 51,5\%, Palestras com especialistas.

Esses resultados corroboram os resultados da pesquisa realizada por Yoshida (2011), que apresenta os métodos de: Cenários, Pesquisa de Mercado, e Previsões e Projeções de Executivos e Forças de Vendas e Distribuidores, como os mais respondidos. Em relação aos menos respondidos, em sua pesquisa, os métodos Delphi e Bibliometria e Patentes foram os menos respondidos, e nesta pesquisa, obteve-se um resultado um pouco diferente com Análise Morfológica, tendo menos utilização que Delphi.

\subsubsection{Corporate foresight e o horizonte de tempo}

A segunda pergunta do questionário possuía como objetivo coletar dados sobre o horizonte de tempo da utilização de cada método. Com isso, a partir dos métodos que os respondentes selecionavam na primeira pergunta, foi pedido que sinalizassem para qual horizonte de tempo esses eram praticados. A tabela 5 explicita os resultados dessa questão: 
Tabela 5 - Métodos de prospecção por horizonte de tempo

\begin{tabular}{|c|c|c|c|c|c|c|c|c|c|c|}
\hline & Delphi & Cenários & Roadmaps & $\begin{array}{l}\text { Bibliometria } \\
\text { e Patentes }\end{array}$ & $\begin{array}{c}\text { Métodos } \\
\text { Matemáticos }\end{array}$ & $\begin{array}{l}\text { Palestras } \\
\text { com Espec. }\end{array}$ & $\begin{array}{l}\text { Pesquisa de } \\
\text { mercado }\end{array}$ & $\begin{array}{l}\text { Prev. Proj. de } \\
\text { Executivos }\end{array}$ & $\begin{array}{c}\text { Análise } \\
\text { Morfológica }\end{array}$ & Total \\
\hline Próx.Trimestre & 0 & 6 & 1 & 0 & 0 & 2 & 3 & 8 & 0 & 20 \\
\hline Até 6 meses & 2 & 5 & 1 & 1 & 2 & 3 & 8 & 4 & 1 & 27 \\
\hline Até 1 ano & 2 & 8 & 6 & 1 & 7 & 12 & 13 & 19 & 2 & 70 \\
\hline Até 2 anos & 2 & 7 & 6 & 2 & 2 & 5 & 18 & 4 & 1 & 47 \\
\hline Até 3 anos & 2 & 8 & 6 & 0 & 3 & 4 & 7 & 4 & 0 & 34 \\
\hline Até 5 anos & 3 & 15 & 7 & 0 & 5 & 9 & 7 & 6 & 0 & 52 \\
\hline Mais de 5 anos & 6 & 13 & 6 & 3 & 1 & 4 & 7 & 3 & 0 & 43 \\
\hline Total & 17 & 62 & 33 & 7 & 20 & 39 & 63 & 48 & 4 & 293 \\
\hline
\end{tabular}

Fonte: a autora.

Referente à variável horizonte de tempo, é possível analisá-la de forma segregada, por tipo de método de prospecção; assim: o método Delphi teve uma média de dois horizontes de tempo diferentes, por respondente, ou seja, alguns respondentes marcaram que utilizam esse método, com o objetivo de analisar o futuro, em duas perspectivas de tempo distintas, porém, o que prevaleceu foi a perspectiva de mais de 5 anos, com 35,29\% das marcações.

O método de Cenários, segunda metodologia mais utilizada pela amostra estudada, possui um horizonte de tempo de até 5 anos (24,2\%), seguido do horizonte de mais de 5 anos, com 21\%. O Roadmaps Tecnológico apresenta maior percentual, em um horizonte de tempo de até 5 anos (21,2\%). E o método de Bibliometria e Patentes, com 42,9\% dos respondentes, informando que utilizam para mais de 5 anos.

Os Métodos Matemáticos e a Palestras com Especialistas possuíram maior percentual, na mesma categoria de tempo, que é até 1 ano; a proporção de marcações nos métodos matemáticos foi de $35 \%$, e em palestras com especialistas, de $30,77 \%$. O método de Pesquisa de Mercado foi selecionado, em sua maioria, até 2 anos (28,57\%); Previsões e Projeções de Executivos, com horizonte de tempo de até 1 ano (39,58\%); e por fim, o método menos utilizado pela amostra, Análise Morfológica, com 50\% das marcações em até 1 ano.

Resumindo, os métodos Delphi, Cenários, Roadmaps e Bibliometria e Patentes foram selecionados como métodos que visam à prospecção de mais longo prazo, estando, em média, com horizontes de 5 anos ou mais. Os Métodos Matemáticos, Palestras com Especialistas, Pesquisa de Mercado, Previsões e Projeções de Executivos e Análise Morfológica apresentaram 
resultados de horizontes de tempo mais curtos: mínimo de 1 ano e máximo de 2 .

Assim, é possível analisar que os métodos Delphi e Cenários tendem a analisar um futuro a longo prazo, e os métodos restantes (Métodos Matemáticos, Palestras com Especialistas, Pesquisa de Mercado, Previsões e Projeções de Executivos) tendem a curto prazo.

Portanto, de forma conclusiva, é possível notar que as empresas dessa amostra estão utilizando cada vez mais as técnicas de corporate foresight, tendo como uma média de utilização, 3 técnicas distintas por empresa. Logo, os números estão indo ao encontro da literatura, que explicita que o corporate foresight é considerado, por um número crescente de empresas, como a ferramenta de escolha no momento de preparação dos negócios para o futuro (Daheim \& Uerz, 2006)

Referente à informação de horizonte de tempo, não foram constatadas muitas análises específicas que medem a utilização dos métodos com algum respectivo horizonte de tempo. Porém, é possível observar que, no atual contexto de tecnologia e de anseio das empresas em prospectar o futuro próximo com o intuito de não se tornarem obsoletas comparativamente às outras, os métodos que visam ao curto prazo estão crescendo. Dentre esses métodos, estão: Pesquisa de Mercado (método mais utilizado), os Métodos Matemáticos, Palestras com Especialistas, Previsões e Projeções de Executivos e Análise Morfológica. De acordo o estudo realizado por Yoshida (2011), o curto prazo mobiliza os gestores das empresas, tendendo a um maior envolvimento e engajamento na atividade de planejamento.

Entretanto, ainda com o crescente uso de métodos de curto prazo, é necessário evidenciar que o método de Cenários, que possui uma maior utilização para prospectar a longo prazo, encontra-se como o segundo método mais utilizado pela amostra estudada. Segundo Yoshida (2011), quando as empresas utilizam métodos de longo prazo tendem a recorrer a métodos que envolvem pessoas e facilitam o debate, sendo essa uma das características do método de Cenários. 


\subsection{Inovação}

Este tópico irá tratar sobre os tipos de inovação mais utilizados pelas respectivas empresas e o modo como elas inovam, lembrando que todas essas categorias, referentes a tipos e modos de inovar, foram referenciadas no tópico de referencial teórico deste estudo.

\subsubsection{Tipos de inovação}

A pergunta de número 3 do questionário foi referente aos tipos de inovação praticados pelas empresas respondentes. Foram disponibilizadas cinco alternativas de respostas, sendo elas: inovação de produto, processo, organizacional e de marketing, definidas de acordo com o último manual de Oslo (Mortensen \& Bloch, 2005), e a opção de inovação de modelo de negócio, conceito mais recente, definida por Chesbrough (2010), como inovações que geram valor por meio de mudanças no modelo de negócio da empresa.

Seguem os resultados, em ordem decrescente de frequência, na tabela 6, e em ordem de entrada, no gráfico 5:

Tabela 6 - Frequência de tipos de inovação

\begin{tabular}{ccc}
\hline Tipos de inovação & Frequência & $\%$ (100\% - 68) \\
\hline Inovações de Produtos & 55 & $80,88 \%$ \\
Inovações de Processo & 51 & $75,00 \%$ \\
Inovações de Modelo de Negócios & 45 & $66,18 \%$ \\
Inovações Organizacionais & 26 & $38,24 \%$ \\
Inovações de Marketing & 26 & $38,24 \%$ \\
\hline
\end{tabular}

Fonte: a autora. 
Gráfico 5 - Número de tipos de inovação por respondente

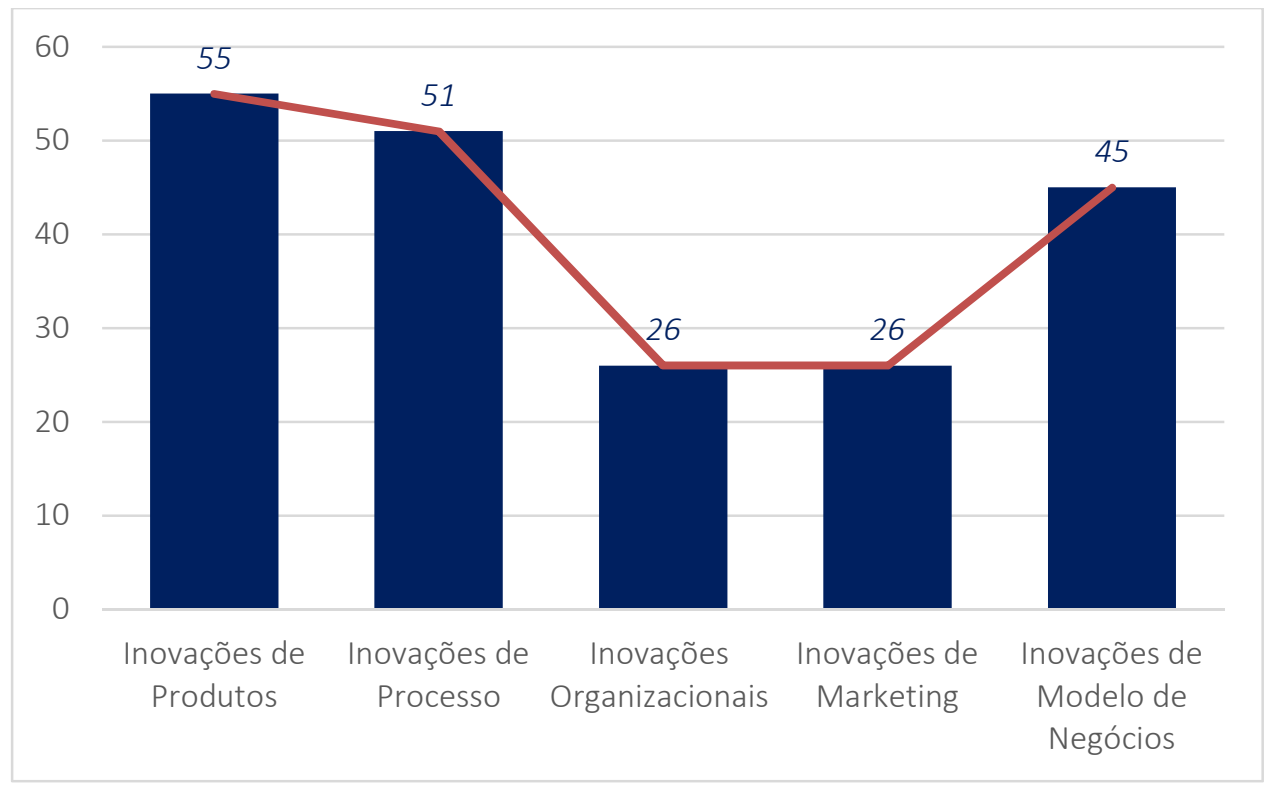

Fonte: a autora.

Dado que foram 203 marcações totais, nessa pergunta, têm-se uma média de 3 tipos de inovação utilizada por respondente (empresa).

Portanto, referente aos resultados ligados aos tipos de inovação, é possível constatar que, hoje, as inovações de produto, processo e modelo de negócio são as mais utilizadas pelas empresas da amostra estudada. As inovações de produto e processo são tipologias de inovação explicitadas há um tempo na literatura e no contexto corporativo. Schumpeter (1934) já citava como possíveis exemplos de inovação, a introdução de novos produtos e a introdução de novos produtos de produção.

Além disso, a inovação de modelo de negócio ganha sua importância no contexto corporativo, a partir do momento que as empresas não querem somente inovar, e sim, executar algo que traga valor ao seu negócio. Assim, como citado por Chesbrough (2010), a mesma tecnologia comercializada de duas maneiras diferentes, produzirá dois retornos diferentes; logo, não basta apenas inovar, e sim, gerar valor por meio dessa inovação. 


\subsubsection{Modos de inovar}

Na pergunta 4 do questionário, o respondente foi indagado em relação ao modo como sua empresa inova, sendo que as opções eram: inovação realizada de forma centralizada na matriz e repassada para unidades internacionais, inovação realizada de forma descentralizada, ou seja, todas as unidades internacionais possuem liberdade para executar processos de inovação, e por fim, inovação aberta, método inbound, é realizada por meio de aquisição de ideias e/ou tecnologias externas que são incorporadas internamente à organização.

Os respondentes podiam optar por mais de um modo de inovação, desde que essas fossem as seguintes combinações: modo centralizado e inovação aberta, ou modo descentralizado e inovação aberta.

Seguem os resultados, em ordem decrescente de frequência, na tabela 7:

Tabela 7 - Frequência de modos de inovar

\begin{tabular}{ccc}
\hline Tipos de inovação & Frequência & $\%$ (100\% - 68) \\
\hline Inovação Aberta (Método Inbound) & 33 & $48,53 \%$ \\
Inovação Centralizada na Matriz & 32 & $47,06 \%$ \\
Inovação Descentralizada na Matriz & 26 & $38,24 \%$ \\
Centralizado + Inovação Aberta & 11 & $16,18 \%$ \\
Descentralizado + Inovação Aberta & 13 & $19,12 \%$ \\
\hline
\end{tabular}

Fonte: a autora.

Por meio dos dados, é possível observar que as maiores frequências de modos de inovar são: inovação aberta e inovação de forma centralizada, sendo esses, respectivamente, 48,53\% e $47,06 \%$ dos respondentes. Além disso, 19,12\% dos respondentes alegaram que utilizam tanto o modo descentralizado de inovar quanto o método de inovação aberta; e 16,18\% utilizam o método centralizado, juntamente com o método de inovação aberta. Assim, é interessante observar que a inovação aberta está ganhando um espaço relevante como metodologia funcional de inovação.

Uma segunda análise referente aos modos de inovar é a sua relação com os tipos de inovação. Os dados foram compilados em grupo de modos de inovar por tipo de inovação, ou seja, 
respondentes que indicaram que praticam inovação de produto, por exemplo, quais foram os modos de inovar em produto que eles também indicaram. Seguem os resultados, na tabela 8:

Tabela 8 - Frequência de modos de inovar por tipo de inovação

\begin{tabular}{|c|c|c|c|c|c|}
\hline & $\begin{array}{c}\text { Inovações de } \\
\text { Produtos }\end{array}$ & $\begin{array}{c}\text { Inovações de } \\
\text { Processo }\end{array}$ & $\begin{array}{c}\text { Inovações } \\
\text { Organizacionais }\end{array}$ & $\begin{array}{c}\text { Inovações de } \\
\text { Marketing }\end{array}$ & $\begin{array}{c}\text { Inovações de Modelo } \\
\text { de Negócios }\end{array}$ \\
\hline Inovação Centralizada na Matriz & 28 & 23 & 13 & 12 & 25 \\
\hline Inovação Descentralizada da Matriz & 24 & 21 & 11 & 13 & 17 \\
\hline Inovação Aberta (Método Inbound) & 26 & 27 & 14 & 14 & 23 \\
\hline
\end{tabular}

Fonte: a autora.

Os três tipos de inovação mais citados, como referenciado no tópico Tipos de Inovação, foram inovações de produtos, processos e de modelo de negócio; logo, pode-se observar que eles possuem, também, maior frequência. Além do mais, quando se trata de modos de inovar, notase que existe uma maior incidência de executarem-se inovações de produto, por meio de inovação centralizada, seguido de inovação aberta. Nessa mesma linha, as inovações de processo têm uma maior incidência de serem executadas, por meio de inovação aberta, e as inovações de modelo de negócio, por meio de inovação centralizada. Os tipos de inovação de marketing e organizacional tiveram uma maior frequência de serem executadas, por meio de inovação aberta.

Vale ressaltar que mesmo os respondentes, tendo indicado que praticam a inovação por modo centralizado, existe uma complementaridade com o método de inovação aberta. Essa questão corrobora mudança de mindset dos gestores para uma visão de criar parcerias externas que gerem valor a suas empresas. Isso condiz com a teoria que diz que a inovação aberta influencia positivamente a performance de uma organização (Dodgson et al., 2006; Gassmann et al., 2010).

Portanto, é possível notar referente aos resultados ligados à inovação, que as empresas estão utilizando tipos variados de inovação, e nota-se a crescente utilização da inovação de modelo de negócio, mostrando, assim, a preocupação dos executivos em não apenas inovar, e sim, gerar valor pela forma que essa inovação é utilizada / comercializada.

Além disso, os resultados explicitam que a tendência em utilizar o modo de inovação aberta é 
crescente, sendo esse executado por $48,5 \%$ da amostra estudada, além dos 35,3\% que utilizam a inovação aberta juntamente com o modo centralizado ou descentralizado. Assim, nota-se que existe um aumento na utilização da inovação de modelo de negócio e do método de inovação aberta, relacionando-se com o que menciona Chesbrough et al. $(2006,2014)$, que, devido ao crescimento progressivo do interesse acadêmico em inovação aberta, essa, também, tornouse, concomitantemente, uma prática disseminada nas organizações.

\subsection{Corporate foresight e inovação}

Esse tópico será dedicado a analisar a interação dessas duas variáveis, referente aos parâmetros de inovação, nível de integração, e por fim, a satisfação dos respondentes perante essa relação.

\subsubsection{Corporate foresight e os parâmetros de inovação}

Um dos pontos-chave desta pesquisa é o estudo da relação entre as variáveis prospecção do futuro e o processo de inovação. Como já explicitado, corporate foresight pode ser entendido como uma orientação global para o futuro de uma organização, e é considerado uma parte da gestão da inovação empresarial (Gruber \& Venter, 2006; Ruff, 2006). Assim, foi perguntado, na questão 6 do questionário, sobre como os métodos de prospeç̧ão contribuem mais para o processo de inovação na empresa. O respondente possuía cinco parâmetros como opção, definidos de acordo com Burmeister et al. (2004):

I A antecipação da procura futura;

II Uma maior qualidade do processo através de informações importantes;

III Orientação ao contexto inserido;

IV Construção de cronograma de inovação factível;

V Identificação de inovações estratégicas para o seu negócio.

O primeiro bloco de respostas é referente à frequência para cada tipo de parâmetro; cada respondente podia marcar mais de uma opção, caso essa situação se encaixasse com a realidade da empresa na qual ele trabalha. 
Os resultados em ordem decrescente de frequência podem ser observados na tabela 9.

Tabela 9 - Frequência dos parâmetros de inovação

\begin{tabular}{lcc}
\hline & Frequência & $\%(100 \%-68)$ \\
\hline Identificação de inovações estratégicas para o seu negócio & 46 & $67,65 \%$ \\
Na antecipação da procura futura de alguma ideia inovadora & 32 & $47,06 \%$ \\
Aumenta a qualidade do processo de inovação, através das informações & 29 & $42,65 \%$ \\
importantes coletadas & 28 & $41,18 \%$ \\
Orientação ao contexto no qual ela será inserido & 22 & $32,35 \%$ \\
Construção de cronograma de implementação factível da inovação estudada & & \\
\hline
\end{tabular}

Fonte: a autora.

Como pode-se notar, os dois parâmetros mais citados, em ordem crescente, foram: identificação de inovações estratégicas para o seu negócio, e antecipação da procura futura de alguma ideia inovadora. Segundo Burmeister et al. (2004), o parâmetro de identificação de inovações estratégicas é utilizar os métodos de prospecção para identificar inovações potenciais; assim, é possível notar que, segundo as empresas estudadas, esse é o tipo de apoio mais utilizado, com 67,65\% da amostra.

Além das frequências absolutas dos parâmetros de inovação, foi realizada a combinação de dados entre os parâmetros e os métodos de prospecção do futuro. A ideia da combinação é trazer uma visão de quais são os parâmetros mais citados por tipos de métodos de prospecção. Os resultados absolutos podem ser observados, a seguir, na tabela 10:

Tabela 10 - Frequência de parâmetros de inovação por tipo de método de prospecção

\begin{tabular}{|c|c|c|c|c|c|}
\hline & $\begin{array}{l}\text { Na antecipação da } \\
\text { procura futura de } \\
\text { alguma ideia } \\
\text { inovadora }\end{array}$ & $\begin{array}{l}\text { Aumenta a qualidade } \\
\text { do processo de } \\
\text { inovação, através das } \\
\text { informações }\end{array}$ & $\begin{array}{l}\text { Orientações ao } \\
\text { contexto no } \\
\text { qual ela será } \\
\text { inserido }\end{array}$ & $\begin{array}{c}\text { Construção de } \\
\text { cronograma de } \\
\text { implementação factível } \\
\text { da inovação estudada }\end{array}$ & $\begin{array}{l}\text { Identificação de } \\
\text { inovações } \\
\text { estratégicas para o } \\
\text { seu negócio }\end{array}$ \\
\hline Pesquisa de mercado & 23 & 19 & 22 & 14 & 33 \\
\hline Cenários & 20 & 20 & 20 & 15 & 35 \\
\hline Prev. Proj. de Executivos & 21 & 18 & 20 & 16 & 29 \\
\hline Palestras com especialistas & 18 & 15 & 15 & 9 & 24 \\
\hline Roadmaps & 9 & 8 & 11 & 12 & 18 \\
\hline Métodos matemáticos & 9 & 10 & 8 & 6 & 13 \\
\hline Delphi & 5 & 3 & 5 & 4 & 5 \\
\hline Bibliometria e patentes & 2 & 2 & 3 & 2 & 3 \\
\hline Análise morfológica & 1 & 1 & 1 & 1 & 1 \\
\hline Total & 108 & 96 & 105 & 79 & 161 \\
\hline
\end{tabular}

Fonte: a autora. 
E os resultados, em forma de porcentagem, podem ser observados na tabela 11 :

Tabela 11 - Porcentagens de inovação por tipo de método de prospecção

\begin{tabular}{|c|c|c|c|c|c|}
\hline & $\begin{array}{l}\text { Na antecipação da } \\
\text { procura futura de } \\
\text { alguma ideia } \\
\text { inovadora }\end{array}$ & $\begin{array}{l}\text { Aumenta a qualidade } \\
\text { do processo de } \\
\text { inovação, através das } \\
\text { informações }\end{array}$ & $\begin{array}{l}\text { Orientações ao } \\
\text { contexto no } \\
\text { qual ela será } \\
\text { inserido }\end{array}$ & $\begin{array}{c}\text { Construção de } \\
\text { cronograma de } \\
\text { implementação factível } \\
\text { da inovação estudada }\end{array}$ & $\begin{array}{l}\text { Identificação de } \\
\text { inovações } \\
\text { estratégicas para o } \\
\text { seu negócio }\end{array}$ \\
\hline Pesquisa de mercado & $33,82 \%$ & $27,94 \%$ & $32,35 \%$ & $20,59 \%$ & $48,53 \%$ \\
\hline Cenários & $29,41 \%$ & $29,41 \%$ & $29,41 \%$ & $22,06 \%$ & $51,47 \%$ \\
\hline Prev. Proj. de Executivos & $30,88 \%$ & $26,47 \%$ & $29,41 \%$ & $23,53 \%$ & $42,65 \%$ \\
\hline Palestras com especialistas & $26,47 \%$ & $22,06 \%$ & $22,06 \%$ & $13,24 \%$ & $35,29 \%$ \\
\hline Roadmaps & $13,24 \%$ & $11,76 \%$ & $16,18 \%$ & $17,65 \%$ & $26,47 \%$ \\
\hline Métodos matemáticos & $13,24 \%$ & $14,71 \%$ & $11,76 \%$ & $8,82 \%$ & $19,12 \%$ \\
\hline Delphi & $7,35 \%$ & $4,41 \%$ & $7,35 \%$ & $5,88 \%$ & $7,35 \%$ \\
\hline Bibliometria e patentes & $2,94 \%$ & $2,94 \%$ & $4,41 \%$ & $2,94 \%$ & $4,41 \%$ \\
\hline Análise morfológica & $1,47 \%$ & $1,47 \%$ & $1,47 \%$ & $1,47 \%$ & $1,47 \%$ \\
\hline
\end{tabular}

Fonte: a autora.

Devido ao caráter exploratório da pesquisa, por meio das tabelas 10 e 11, é possível observar quais os métodos foram mais citados, por tipos de parâmetros. Exemplo: quando uma empresa utiliza alguma técnica de prospecção do futuro, quais são os parâmetros de inovação que os seus executivos acreditam que esses métodos auxiliam. Como mostrado, acima, houve um consenso de todos os métodos de prospecção com o parâmetro de "identificação de inovações estratégicas para o negócio". Assim, é interessante observar que o parâmetro de identificação de inovações estratégicas é inicial a um processo de inovação, pois, primeiro, prospecta-se a inovação que se deseja realizar, para, depois, poder efetivamente realizá-la.

E o parâmetro de "construção de cronograma de implementação factível da inovação estudada" foi o menos votado dentre os métodos de pesquisa de mercado, cenário, previsões e projeções de executivos, palestras com especialistas e métodos matemáticos. Esse parâmetro de inovação pode ser considerado como mais avançado, dado que já está na fase de implementação da inovação. Logo, os resultados indicam que os executivos estão utilizando os métodos prospectivos como forma de apoio, nas fases iniciais de processos de inovação, ainda não tendo evoluído para um apoio mais avançado.

Quando se observa o resultado do ponto de vista dos parâmetros de inovação, ou seja, qual método de prospecção foi mais citado por tipo de parâmetro, nota-se que, para todos os parâmetros, os métodos mais utilizados foram: Pesquisa de mercado; depois, Cenários; e em 
terceiro, Previsões e projeções de executivos. Esses métodos foram os mais citados, por serem os mais utilizados pelas empresas - quando os executivos procuram algum método, seja para identificar alguma oportunidade futura, ou construir um cronograma mais factível para a inovação, ou para atingir algum outro parâmetro da tabela 11, esses ainda são os métodos mais utilizados.

Portanto, os resultados mostram uma tendência dos métodos de corporate foresight estarem cada vez mais integrados com os objetivos de inovação de uma organização, ou seja, que a utilização do método como forma de suporte à inovação está sendo vista como uma ferramenta valorosa para uma organização; assim, indo ao encontro com o que a literatura traz, que os objetivos principais de uma estratégia ligada à inovação requerem uma detecção prévia de oportunidades futuras e riscos (Ruff, 2006). Daheim et al. (2013) corroboram esse ponto e complementam que o corporate foresight está tornando-se cada vez mais difundido, profissional e diversificado, quando se trata de sua utilização para fins de inovação.

\subsubsection{Nível de integração}

De acordo com a literatura é possível identificar três níveis de integração, entre os métodos de prospecção e o processo de inovação, sendo esses um nível mais fraco, chamado de ad hoc, um nível de integração médio, e um nível de integração total (Van der Duin, 2006). Assim, na questão 5 do questionário foi perguntado ao respondente qual o nível de integração que ele acredita que a empresa dele encontra-se.

Os resultados podem ser verificados no gráfico 6 e na tabela 12, abaixo: 
Gráfico 6 - Nível de intensidade entre a prospecção e o processo de inovação

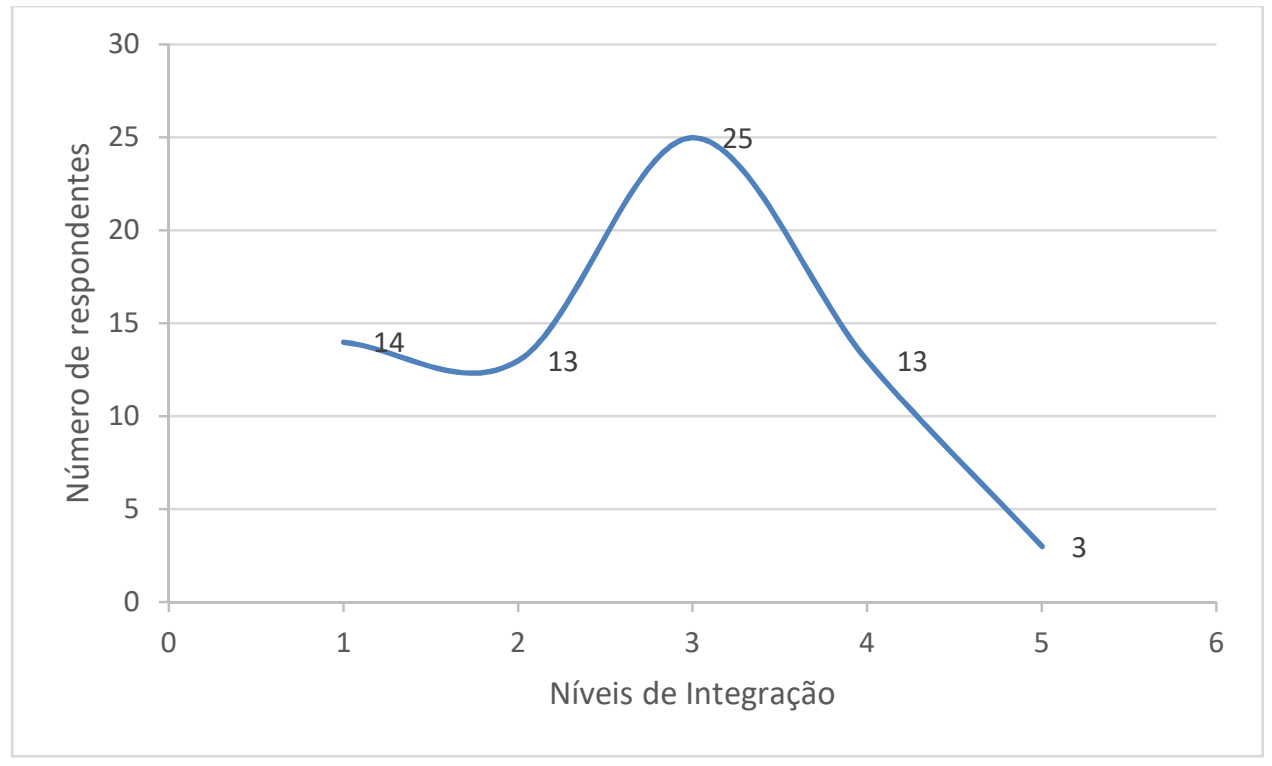

Fonte: a autora.

Tabela 12 - Frequência de níveis de integração

\begin{tabular}{ccc}
\hline Níveis & Frequência & $\%(100 \%-68)$ \\
\hline 1 & 14 & $20,59 \%$ \\
2 & 13 & $19,12 \%$ \\
3 & 25 & $36,76 \%$ \\
4 & 13 & $19,12 \%$ \\
5 & 3 & $4,41 \%$ \\
\hline \multicolumn{3}{c}{ Fonte: a autora. }
\end{tabular}

O gráfico 6 mostra como se dá a distribuição de número de respondentes por nível de integração, e a tabela 12 traz as frequências e as suas devidas proporções. Como é possível observar, $36,76 \%$ das empresas se encontram no nível de integração 3, mostrando uma tendência da curva estar deslocada mais para esquerda do que para direita. Esse resultado é demostrado por uma diminuição de respondentes que acreditam que as suas empesas estejam no nível mais elevado de integração, dando margem à interpretação de que existe um processo de maturação na utilização das técnicas de prospecção como suporte para o processo de inovação.

Assim, pode-se observar que as empresas estão em um processo de sair de uma integração ad hoc, onde os processos de inovação e de pesquisas do futuro são apartados, para o método de 
integração, onde os processos já começam a ter uma ligação na origem, ou seja, os executivos pensam em fazer método de pesquisas do futuro como forma de apoio à inovação. É importante enfatizar que Van der Duin (2004) não coloca nenhum tipo de juízo de valor sobre os graus de integração, ou seja, uma empresa é mais eficiente ao inovar quando o nível de integração é o completo, e sim, traz que existem esses níveis, e é um processo evolutivo que as empresas vão se interessando por unificar os métodos de prospecção com o processo de inovação. Logo, nota-se que as empresas analisadas neste estudo encontram-se nesse processo evolutivo, tendendo a um nível mais elevado de integração, onde os executivos desejam utilizar o método com o fim específico de inovar.

\subsubsection{Nível de satisfação}

A última pergunta do questionário foi referente ao grau de satisfação dos respondentes em relação aos métodos de prospecção apoiarem o processo de inovação. Assim, a pergunta foi feita da seguinte maneira: o respondente deveria indicar de 1 (totalmente insatisfeito) até 7 (totalmente satisfeito), se o método de prospecção atende a suas necessidades para a empresa inovar / iniciar um processo de inovação. A resposta era selecionada, individualmente, por tipo de método.

Essa pergunta é de extrema importância para a pesquisa, pois ela fecha o ciclo de avaliação da relação entre os métodos de prospecção e o processo inovação. Primeiro, foi avaliado em quais parâmetros de inovação os métodos de prospecção mais deram suporte, para que o parâmetro ocorresse; depois, foi avaliado o nível de integração entre essas duas variáveis, com o principal intuito de avaliar a maturidade dessa relação nas empresas; e por fim, analisar, de forma subjetiva, a percepção do gestor sobre a criação de valor dessa união (tabela 13). 
Tabela 13 - Frequência de grau de satisfação por tipo de método de prospecção

\begin{tabular}{|c|c|c|c|c|c|c|c|c|}
\hline & $\begin{array}{l}\text { Totalmente } \\
\text { Insatisfeito }\end{array}$ & $\begin{array}{c}\text { Muito } \\
\text { Insatisfeito }\end{array}$ & Insatisfeito & Indiferente & Satisfeito & $\begin{array}{c}\text { Muito } \\
\text { Satisfeito }\end{array}$ & $\begin{array}{l}\text { Totalmente } \\
\text { Satisfeito }\end{array}$ & Total \\
\hline Delphi & 2 & 1 & 1 & 2 & 11 & 3 & 2 & 22 \\
\hline Cenários & 1 & 3 & 3 & 4 & 26 & 12 & 1 & 50 \\
\hline Roadmaps & 2 & 0 & 3 & 5 & 13 & 5 & 1 & 29 \\
\hline Bibliometria e patentes & 1 & 1 & 1 & 2 & 2 & 1 & 0 & 8 \\
\hline Métodos matemáticos & 1 & 0 & 1 & 8 & 4 & 5 & 2 & 21 \\
\hline Palestras com especialistas & 2 & 2 & 0 & 8 & 24 & 9 & 0 & 45 \\
\hline Pesquisa de mercado & 2 & 0 & 5 & 10 & 24 & 12 & 0 & 53 \\
\hline Prev. e Proj. de executivos & 2 & 2 & 6 & 3 & 23 & 7 & 1 & 44 \\
\hline Análise morfológica & 2 & 0 & 0 & 2 & 0 & 2 & 0 & 6 \\
\hline Total & 15 & 9 & 20 & 44 & 127 & 56 & 7 & 278 \\
\hline
\end{tabular}

Fonte: a autora.

Assim, os resultados foram os seguintes:

E os resultados, em forma de porcentagem, podem ser observados na tabela 14, abaixo:

Tabela 14 - Frequência em porcentagem do grau de satisfação por tipo de método de prospecção

\begin{tabular}{|c|c|c|c|c|c|c|c|c|}
\hline & $\begin{array}{l}\text { Totalmente } \\
\text { Insatisfeito }\end{array}$ & $\begin{array}{c}\text { Muito } \\
\text { Insatisfeito }\end{array}$ & Insatisfeito & Indiferente & Satisfeito & $\begin{array}{c}\text { Muito } \\
\text { Satisfeito }\end{array}$ & $\begin{array}{l}\text { Totalmente } \\
\text { Satisfeito }\end{array}$ & Total \\
\hline Delphi & $9,09 \%$ & $4,55 \%$ & $4,55 \%$ & $9,09 \%$ & $50,00 \%$ & $13,64 \%$ & $9,09 \%$ & $100,00 \%$ \\
\hline Cenários & $2,00 \%$ & $6,00 \%$ & $6,00 \%$ & $8,00 \%$ & $52,00 \%$ & $24,00 \%$ & $2,00 \%$ & $100,00 \%$ \\
\hline Roadmaps & $6,90 \%$ & $0,00 \%$ & $10,34 \%$ & $17,24 \%$ & $44,83 \%$ & $17,24 \%$ & $3,45 \%$ & $100,00 \%$ \\
\hline Bibliometria e patentes & $12,50 \%$ & $12,50 \%$ & $12,50 \%$ & $25,00 \%$ & $25,00 \%$ & $12,50 \%$ & $0,00 \%$ & $100,00 \%$ \\
\hline Métodos matemáticos & $4,76 \%$ & $0,00 \%$ & $4,76 \%$ & $38,10 \%$ & $19,05 \%$ & $23,81 \%$ & $9,52 \%$ & $100,00 \%$ \\
\hline Palestras com especialistas & $4,44 \%$ & $4,44 \%$ & $0,00 \%$ & $17,78 \%$ & $53,33 \%$ & $20,00 \%$ & $0,00 \%$ & $100,00 \%$ \\
\hline Pesquisa de mercado & $3,77 \%$ & $0,00 \%$ & $9,43 \%$ & $18,87 \%$ & $45,28 \%$ & $22,64 \%$ & $0,00 \%$ & $100,00 \%$ \\
\hline Prev. e Proj. de executivos & $4,55 \%$ & $4,55 \%$ & $13,64 \%$ & $6,82 \%$ & $52,27 \%$ & $15,91 \%$ & $2,27 \%$ & $100,00 \%$ \\
\hline Análise morfológica & $33,33 \%$ & $0,00 \%$ & $0,00 \%$ & $33,33 \%$ & $0,00 \%$ & $33,33 \%$ & $0,00 \%$ & $100,00 \%$ \\
\hline
\end{tabular}

Fonte: a autora.

Como pode ser observado, na coluna total, os métodos que tiveram mais votações foram aqueles mais indicados como utilizados pelas empresas. Em relação à frequência absoluta de respondentes que votaram por grau de satisfação, 46\% dos respondentes (127) encontram-se satisfeitos com esse apoio, seguidos de 20\%, muito satisfeitos, e 16\%, indiferentes. O que é possível observar, por meio desses números, é a relação com o seu grau de maturidade explicitado no tópico acima sobre nível de integração. Dado que as empresas encontram-se, ainda, em um processo de maturação desse processo, é esperado que os seus executivos avaliem os métodos como satisfatórios, mas, ainda, com um potencial de excelência a ser alcançado por esses métodos, como apoiadores ao processo de inovação, segundo a percepção 
dos respondentes.

Além da análise pela escala de satisfação da tabela 13, foram compiladas as sete classes, mostradas nessa tabela, em três classes menores, com o intuito de facilitar a análise agregada dos dados. Assim, na tabela 15, é possível observar a distribuição das respostas pelos seguintes graus: insatisfeito, indiferente e satisfeito.

Tabela 15 - Frequência de grau de satisfação por três classes

\begin{tabular}{lcccc}
\hline & Insatisfeito & Indiferente & Satisfeito & Total \\
\hline Delphi & 4 & 2 & 16 & 22 \\
Cenários & 7 & 4 & 39 & 50 \\
Roadmaps & 5 & 5 & 19 & 29 \\
Bibliometria e patentes & 3 & 2 & 3 & 8 \\
Métodos matemáticos & 2 & 8 & 11 & 21 \\
Palestras com especialistas & 4 & 8 & 33 & 45 \\
Pesquisa de mercado & 7 & 10 & 36 & 53 \\
Prev. e Proj. de executivos & 10 & 3 & 31 & 44 \\
Análise morfológica & 2 & 2 & 2 & 6 \\
\hline \multicolumn{1}{c}{ Total } & 44 & 44 & 190 & 278 \\
\hline
\end{tabular}

Fonte: a autora.

A partir desses dados agregados em classes consolidadas, é possível observar que os graus insatisfeito e indiferente são os mesmos, e o grau satisfeito possui a maioria das marcações, com $68 \%$ das respostas. Corroborando o que foi explicitado da tabela 13, os respondentes ainda não se consideram totalmente satisfeitos com o apoio dado pelos métodos prospectivos, mas, observa-se uma tendência que, com o aumento da maturidade dessa relação, as empresas encontrem-se cada vez mais satisfeitas.

Para finalizar essa análise, foi elaborada a tabela 16, com a proporção de satisfação por método prospectivo; essa informação é relevante para analisar qual método os executivos encontramse mais satisfeitos, dado o número de respondentes que a utilizam. Assim, elimina-se a possibilidade de algum método ser "pior" avaliado no grau de satisfação, por não ser amplamente utilizado nas empresas, sendo que as pessoas que as utilizam (mesmo sendo poucas, em quantidade) consideram como um bom método de apoio ao processo de inovação. 
Os resultados encontram-se na tabela 16, abaixo:

\begin{tabular}{|c|c|}
\hline Método de Prospecção & $\%$ de Satisfeitos \\
\hline Cenários & $78,00 \%$ \\
\hline Palestras com especialistas & $73,33 \%$ \\
\hline Delphi & $72,73 \%$ \\
\hline Prev. e Proj. de Executivos & $70,45 \%$ \\
\hline Pesquisa de mercado & $67,92 \%$ \\
\hline Roadmaps & $65,52 \%$ \\
\hline Métodos matemáticos & $52,38 \%$ \\
\hline Bibliometria e patentes & $37,50 \%$ \\
\hline Análise morfológica & $33,33 \%$ \\
\hline
\end{tabular}

A tabela 16 possibilita-nos analisar que a metodologia de Cenários dentre todas as outras, é a que mais possui aprovação como uma auxiliadora do processo de inovação, com $78 \%$ dos respondentes, seguida do método de Palestras com Especialistas (73,33\%), Delphi (72,73\%) e Previsões e Projeções de Executivos (70,45\%). Assim, é possível concluir que esse resultado é bastante importante, tanto para literatura quanto para o mundo corporativo, por propiciar um norte de quais são os métodos, hoje, que os executivos / especialistas do mercado acreditam que mais auxiliam o processo de inovação. 


\section{CONSIDERAÇÕES FINAIS}

Essa etapa de considerações finais é composta pela conclusão de todos os resultados apresentados anteriormente, sendo importante ressaltar a relação dos resultados com o que foi proposto de modelo conceitual, além de trazer as limitações de pesquisa, possíveis pesquisas futuras e contribuições práticas e teóricas.

\subsection{Conclusões}

Primeiramente, é importante ressaltar que o objetivo principal deste estudo foi analisar como que a utilização de metodologias de Corporate Foresight pelas empresas apoia o desenvolvimento do processo de inovações de produto, processo, organizacional, marketing e de modelo de negócios. Com esse intuito, foi desenvolvida uma série de perguntas, para que executivos do mercado pudessem responder, e assim, gerar informações que levassem ao objetivo principal da pesquisa.

A etapa de seleção do público respondente do questionário foi bastante importante para chegar-se às informações qualificadas, com o objetivo primário de melhor responder as perguntas de pesquisa. Assim, é possível concluir, do ponto de vista de perfil de respondentes e empresas, que são dados bastante qualificados, dado que as pessoas possuem um alto grau de senioridade, e ademais, as empresas possuem grandes faturamentos, demonstrando sua maturidade no mercado, além de serem de setores diversos, possibilitando que esses dados nos deem uma visão ampla de como funciona a relação do corporate foresight e processo de inovação.

Referente aos resultados de corporate foresight, é possível observar que cada respondente indicou que utiliza, em média, três tipos diferentes de pesquisas do futuro, sendo as mais votadas, pesquisa de mercado, com 67,65\%, seguido de Cenários, com 64,71\%, Previsões e projeções de executivos e forças de vendas e distribuidores em terceiro, com 57,35\%, e em quarto, com 51,47\%, Palestras com especialistas.

A partir dessa informação, é possível inferir que os métodos que possuem maior interação 
entre pessoas são frequentemente mais utilizados, e as técnicas instrumentalizadas e que não possuem essa interação apresentam uma menor adesão, como, por exemplo, roadmaps, metodologias matemáticas, bibliometria e patentes e análise morfológica. É importante frisar, que o único método que fugiu à regra de ser bastante utilizado por possuir maior interação entre as pessoas, foi o método Delphi, que teve pouca indicação de utilização por parte dos respondentes.

Ademais, os resultados encontrados corroboram pesquisas passadas, como exemplificado por Yoshida (2011); assim, é observável que ao longo do tempo, as empresas mantêm-se utilizando métodos de pesquisas do futuro similares, e que a tendência é que cada empresa utilize mais de um método, dado que eles não são mutuamente exclusivos. Essa informação converge para os estudos de Heger e Rohrbeck (2012), que comentam que a ideia de combinar os métodos de foresight tem uma longa história, na literatura, além de Armstrong (1986) ter proposto selecionar métodos baseados em suas vantagens e desvantagens, como, por exemplo, combinar métodos quantitativos e qualitativos.

O segundo ponto analisado sobre a variável corporate foresight foi o seu horizonte de tempo, explicitado no modelo conceitual da pesquisa. Como apresentado na sessão dos resultados, cada método possui um horizonte de tempo distinto para as pessoas que as utilizam. É interessante observar que alguns métodos coincidiram em ser de longo prazo, enquanto outros de curto prazo de prospecção.

Os métodos apontados como mais utilizados para prospecção de longo prazo foram os seguintes: Delphi, Cenários, Roadmaps e Bibliometria e Patentes, que possuem uma média de horizonte de 5 anos ou mais. Com isso, é passível de analisar que metodologias mais robustas como as citadas, tendem a visionar um futuro mais a longo prazo por parte dos executivos. Já, os Métodos Matemáticos, Palestras com Especialistas, Pesquisa de Mercado, Previsões e Projeções de Executivos e Análise Morfológica tendem a ser de curto prazo.

Portanto, referente à variável de corporate foresight, têm-se que os métodos que possuem mais interações entre pessoas costumam ser os mais utilizados pelas empresas, e que técnicas com metodologias mais robustas, ou seja, que tendem a levar um maior tempo para serem 
executadas, costumam ser utilizadas para prospectar um futuro a longo prazo, e em contrapartida os métodos mais dinâmicos visam a prospectar um futuro a curto prazo.

De forma similar a combinação de metodologias de prospecção do futuro, os resultados de inovação demonstram que as empresas costumam utilizar, no mínimo, três tipos de inovações diferentes, justamente pelo fato dessas não serem mutuamente exclusivas. As duas principais inovações citadas pelos respondentes, foram as de produtos, com 80,88\% de marcações, seguida de processos, com 75\%. Essas duas inovações, como referenciadas na revisão da literatura, são definidas pelo manual de Oslo (Mortensen \& Bloch, 2005) como tipos oficiais de inovação.

O terceiro tipo de inovação que mostrou sua significância na base foi a inovação de modelo de negócio, com 66,18\% de empresas que a utilizam. Esse dado confirma a literatura, que exemplifica a importância e a relevância de que esse tipo de inovação está tendo para as empresas. Segundo Chesbrough (2010), "uma tecnologia medíocre executada através de um grande modelo de negócio pode ser mais valiosa que uma grande tecnologia explorada através de um medíocre modelo de negócio". Ainda Trapp, Voigt e Brem (2018) citam que a inovação do modelo de negócios é o processo de integração de uma nova lógica de fazer negócios em uma empresa, com o intuito de melhorar a lucratividade ou capitalizar novos negócios / oportunidades.

O segundo ponto de estudo referente à inovação é o modo como as empresas inovam, sendo desde forma centralizada na matriz (caso seja uma multinacional), forma descentralizada e por meio de inovação aberta (método inbound). A partir dos resultados, o que pode observar-se é uma grande tendência das empresas inovarem por meio da inovação aberta: 48,53\% dos respondentes alegaram que as suas empresas utilizam o método inbound. Esse método de inovar, segundo Chesbrough e Crowther (2006), envolve a aquisição e alavancagem de insumos externos para o desenvolvimento de novas tecnologias internas.

Esse resultado confirma a literatura, quando Chesbrough et al. $(2006,2014)$ sugere que o crescimento progressivo do interesse acadêmico no método de inovação aberta é um reflexo dessa prática ter sido disseminada nas organizações. A literatura refere que esse modo de 
inovar influencia positivamente a performance de uma organização, como citado por Dodgson et al. (2006) e Gassmann et al. (2010).

Uma segunda análise dos modos de inovação são as conclusões observáveis por tipo de inovação. As inovações de produto e de modelo de negócio tiveram mais indicações de serem executadas por modo centralizado. Já, as inovações de processo, marketing e organizacional tiveram maior incidência no modo de inovação aberta. Referente a essa análise, vale ressaltar que não foi possível tirar conclusões estatísticas dessa relação, dado que não foram executados testes de hipóteses, devido ao caráter exploratório da pesquisa, porém é possível observar uma tendência dessa relação.

De forma complementar, é importante enfatizar que os modos de inovação não são mutuamente exclusivos, ou seja, uma empresa pode inovar de forma centralizada e utilizar, conjuntamente, o método de inovação aberta. Assim, outra análise relevante é verificar sobre se as empresas estão utilizando essa combinação de métodos (tabela 17):

Tabela 17 - Frequência de combinação de modos de inovar

\begin{tabular}{ccc}
\hline Combinação de Modos de Inovar & Frequência & $\%(100 \%-68)$ \\
\hline Centralizado + Inovação Aberta & 11 & $16,18 \%$ \\
Descentralizado + Inovação Aberta & 13 & $19,12 \%$ \\
\hline
\end{tabular}

Fonte: a autora.

Nota-se que $19,12 \%$ dos respondentes indicaram que as suas empresas além de executarem processo de inovação por modo descentralizado, também utilizam do método de inovação aberta e $16,18 \%$ das empresas, e executam inovação, de forma centralizada, conjuntamente, com o método de inovação aberta. Portanto, o crescimento da utilização de inovação aberta, tanto de forma individual, quanto unificada com outros tipos de inovação, traz à tona o aumento de sua visibilidade, tanto no meio acadêmico, quanto no corporativo.

Todas as conclusões tiradas, acima, ajudam a responder o objetivo principal desta pesquisa, que é analisar a relação entre o corporate foresight e o processo de inovação. Durante a revisão da literatura, foi mostrada a importância desse tema, tanto no contexto acadêmico, quanto no meio corporativo. Assim, foi construído o modelo conceitual, que detalha dois pontos de 
partida para analisar essa relação, que são os parâmetros de inovação e a intensidade da união das duas variáveis. E por fim, avaliar o nível de satisfação dos executivos, perante o apoio que os métodos prospectivos fornecem para o processo de inovação.

Primeiramente, referente aos parâmetros de inovação, Burmeister et al. (2004) detalham, em seu artigo, que existem cinco tipos distintos, mas não mutuamente exclusivos, de auxílio ao processo de inovação. A pergunta foi realizada aos executivos, com o intuito de poder analisar quais os principais parâmetros de inovação que eles acreditam que os métodos prospectivos melhor auxiliam, e com o intuito de avaliar, também, se existe algum padrão de apoio, ou seja, para que serve o corporate foresight no processo de inovação.

Em relação ao número de marcações, em média, os respondentes acreditam que os métodos prospectivos auxiliem majoritariamente até 2 tipos distintos de parâmetros de inovação. 0 mais votado foi a "identificação de inovações estratégicas para o seu negócio", seguido de "na antecipação da procura futura de alguma ideia inovadora"; o menos votado foi a "construção de cronograma de implementação factível da inovação estudada".

Os dois parâmetros mais votados são considerados iniciais a um processo de inovação, pois uma empresa pode utilizar algum tipo de pesquisa do futuro para saber o que está por vir, e nesta pesquisa, encontrar algum tipo de inovação que faça sentido a seu contexto, quanto essa mesma empresa pode fazer algum tipo de pesquisa focada em encontrar especificamente alguma inovação estratégica. E o parâmetro menos votado, "construção de cronograma de implementação factível da inovação estudada", é considerado final a um processo de inovação, ou seja, a empresa já tem de saber o que precisa / necessita inovar, para, posteriormente, procurar alguma metodologia que a auxilia a construir essa inovação da melhor maneira.

Com o objetivo de identificar se existe algum padrão entre os métodos e os parâmetros mais votados, foi realizada a análise conjunta dessas respostas. O que foi possível observar é que 100\% dos métodos de prospecção tiveram maior votação para o parâmetro de identificação de inovações estratégicas para o negócio, seguindo a lógica explicitada no parágrafo acima, e o parâmetro menos citado foi o mesmo da marcação geral: criação de um cronograma factível. Os dois métodos que não tiveram menor votação, nesse parâmetro, foram os métodos de 
roadmaps e o Delphi.

O método de roadmaps apresentou uma especificidade nessa análise que vai ao encontro da literatura: o parâmetro de construção de cronograma factível foi o segundo mais votado, e segundo Lee e Park (2005), ao final de um roadmaps, o que se obtém é uma visualização de viabilidade da tecnologia consolidada, além de se ter um conhecimento de quanto tempo se levaria, para que isso ocorresse, ou seja, esse método se apresenta como uma boa alternativa de entender-se como construir um cronograma que faça sentido para a inovação prospectada.

Portanto, a conclusão referente aos métodos prospectivos e os parâmetros de inovação é que, na visão dos executivos, os estudos do futuro são metodologias que apoiam o processo inicial de inovação, ainda não tendo amadurecido como completo para etapas mais avançadas desse processo, tendo como exceção o método de roadmaps tecnológicos, que demonstrou ser um método de apoio na etapa de construção do cronograma de implementação, dado que é uma metodologia que possibilita desenhar um mapa de etapas ao longo do tempo, conectando os componentes tecnológicos necessários em um linha do tempo lógica.

O segundo ponto de partida desse tópico é o nível de integração da relação dessas duas variáveis. Segundo Van der Duin (2006), existem três tipos de integração entre os métodos prospectivos e o processo de inovação, partindo de um mais fraco, intermediário, e um mais avançado. Essa variável é importante para avaliar em qual grau de maturação as empresas encontram-se. A partir dos resultados coletados, as empresas mostram-se em um estágio ad hoc (mais fraco) de integração, deslocando fortemente para o estágio intermediário, como é possível observar no gráfico 6 da sessão de resultados.

Isso leva-nos a crer que existe uma tendência de as empresas utilizarem cada vez mais os métodos prospectivos como uma ferramenta / metodologia direcionada ao processo de inovação, ou seja, não somente utilizar um método prospectivo para identificar oportunidades de melhorias futuras, mas, sim, também, como uma forma de apoio direcionado à inovação. Assim como a literatura aponta, a excelência na gestão da inovação está cada vez mais ligada à capacidade de uma empresa estabelecer e fomentar os estudos do futuro (Heiko et al., 2010). 
Por fim, foi avaliado o nível de satisfação dos respondentes ao apoio que os métodos prospectivos fornecem ao processo de inovação. De forma geral, $46 \%$ dos respondentes encontram-se satisfeitos com esse apoio, seguido de $20 \%$, muito satisfeito, e $16 \%$, indiferentes. Essa tendência de satisfação vai ao encontro da própria maturação da integração das variáveis, dado que quanto mais as empresas encontram-se satisfeitas com esse apoio, mais elas tendem a utilizar os métodos prospectivos, juntamente com o processo de inovação.

Além dessa informação, outro ponto substancial consiste de quais são os métodos de prospecção em que as empresas encontram-se mais satisfeitas. Dada a amostra coletada nesta pesquisa, o método de Cenário liderou o ranking, com 78\% dos respondentes satisfeitos, seguido do método de Palestras com especialistas, Delphi e Previsões e Projeções de Executivos.

No tópico de considerações finais da variável corporate foresight, conclui-se que os métodos que possuem interação humana são os mais utilizados pelas empresas respondentes, com exceção do método Delphi, e o que se pode ver nos resultados de satisfeitos que esse resultado é similar: os métodos de Cenários, Palestras com Especialistas, Delphi, Previsões e Projeções de Executivos e Pesquisa de Mercado lideram como os que possibilitam maior satisfação por parte dos executivos que os utilizam.

Desta maneira, com o intuito de analisar como a utilização de metodologias de Corporate Foresight pelas empresas apoia o desenvolvimento do processo de inovação, foi possível analisar tantos métodos mais utilizados, quanto seus respectivos horizontes de tempo que auxiliam executivos no momento de escolher algum método prospectivo, dado algum horizonte de tempo específico, além de avaliar os principais tipos de inovação desenvolvidos, hoje, nas empresas, e como o modo de inovar está sendo revolucionado por meio da inovação aberta.

Ademais, é possível concluir, dadas as explicações acima, que as empresas estão evoluindo na utilização dessa metodologia como forma de suporte ao processo de inovação, visto que a maturação dessa relação está evoluindo, além de elencar momentos do processo de inovação que os executivos enxergam maior apoio. Com toda essa construção de raciocínio, tornou-se 
viável avaliar a satisfação do respondente por cada tipo de métodos, fornecendo assim suporte tanto para literatura evoluir nesse assunto quanto para executivos que ainda não sabem como utilizar os estudos do futuro com fins de inovação. No geral, pode-se afirmar que os métodos de prospecção apoiam inovação e que ainda há potencial para maior utilização e satisfação.

\subsection{Limitações de pesquisa}

Essa pesquisa possui a proposta metodológica exploratória descritiva, com o suporte de um levantamento quantitativo das variáveis do estudo. O principal intuito desse levantamento quantitativo foi responder, de forma consistente, as perguntas de pesquisa, e por fim, chegar à pergunta / objetivo principal de pesquisa.

A limitação deste estudo encontra-se na dificuldade de generalização dos resultados. A amostra selecionada foi definida com base na qualidade dos respondentes, ou seja, foi selecionado o tipo de amostra não-probabilística, que é definida como um subgrupo da população escolhido por meio de suas características de pesquisa e não por sua probabilidade. Assim, na amostragem não-probabilística, os elementos da população não têm a mesma probabilidade de serem selecionados; portanto, não há garantias da representatividade da população.

Por isso, apesar das informações geradas, neste estudo, serem bastante relevantes, deve-se ter prudência ao fazer-se qualquer tipo de generalização para todas as empresas brasileiras e estrangeiras. Além do mais, é importante relembrar, que o intuito inicial deste estudo, como citado, não era fazer inferências para a população, e sim, realizar um estudo exploratório que trouxesse informações adicionais, tanto para contribuições teóricas, quanto práticas.

\subsection{Contribuições práticas e teóricas}

Este estudo teve como principal objetivo analisar como se dá o apoio dos métodos prospectivos aos processos de inovações organizacionais. Com esse intuito, primeiramente foi realizada uma extensa revisão da bibliografia; depois, aplicação do questionário, obtenção dos dados e análise das informações geradas. 
Assim, inicialmente, do ponto de vista prático, o estudo propicia um norte de entendimento muito importante para os executivos das empresas. Esse norte é pautado em ter conhecimento dos seguintes temas: quais são os métodos prospectivos que as empresas estão mais utilizando, ou seja, se por acaso uma determinada empresa não utilizar nenhum tipo de metodologia de pesquisas do futuro, e quiser ter o entendimento de como o mercado encontra-se em relação ao assunto, para, assim, tomar uma decisão de qual método utilizar, esta pesquisa apoia a análise a partir do momento que sintetiza essa informação.

Além disso, os executivos podem ter acesso à informação de qual é o horizonte de tempo de cada método; logo, se uma empresa visar a prospectar o futuro a curto prazo, por meio desta pesquisa, consegue-se fazer uma análise comparativa de quais são os métodos que as outras empresas utilizam, quando desejam prospectar a curto prazo.

Agora, sob a perspectiva de inovação, a contribuição prática que este estudo traz é de quais são as inovações mais utilizadas pelas empresas e qual é a tendência de mudanças, como, por exemplo, o crescimento das inovações de modelo de negócios, que concorda com a visão da literatura de que esse tipo de inovação possibilita o melhoramento da performance das empresas. Assim, consegue-se obter essa informação e utilizá-la como um norte, em termos de inovação para a empresa. Sem citar que caso as empresas estejam querendo realizar um benchmarking de modo de inovação, esta pesquisa traz também essa informação.

Do ponto de vista prático, este estudo contribuiu em orientar quais são os parâmetros do processo de inovação que os métodos prospectivos mais são citados. Assim, uma empresa, caso esteja procurando ter ideias de inovações estratégicas para o seu negócio, pode ter acesso a quais são os métodos prospectivos mais citados para tal; e analisar a tendência de integração entre essas duas variáveis, e perceber o aumento da utilização de métodos prospectivos com o objetivo de auxiliar o processo de inovação. Essas informações são importantes a partir do momento que as organizações podem utilizar dessas ferramentas (métodos prospectivos) como suporte e melhor análise dos processos de inovação de suas respectivas empresas.

Por fim, a principal contribuição teórica desta pesquisa é analisar de forma embasada como se dá a relação dessas duas variáveis, métodos prospectivos e inovação. Foi possível verificar, por 
meio da revisão da literatura, que esse tema possui uma série de lacunas, pois existem poucos artigos que tratam sobre o assunto em tela, além de poucos que tratam da relação dessas suas variáveis, ou seja, estudos que delimitem pontos de partida de análise. Logo, a primeira contribuição é a do próprio fomento do tema, dado que ainda existe bastante campo para os pesquisadores aprofundarem-se.

Além do mais, este estudo contribuiu, teoricamente, por delimitar esses pontos de partida citados, acima, que são os parâmetros de inovação e o nível de intensidade. Por meio deles, é possível estudar a relação dos métodos prospectivos com o processo de inovação pautado em certas premissas, como, por exemplo, quais são os papéis mais desempenhados pelo corporate foresight, quando se trata de inovação, demonstrados por meio do parâmetro de inovação.

Por fim, contribui-se com o amadurecimento do tema, que, hoje, é bastante tratado de forma separada (corporate foresight e inovação), e que, com este estudo, desenvolve-se uma ideia mais madura do ponto de vista teórico. Essa ideia é amadurecida, dado que avança no tema referente aos métodos prospectivos possuírem um papel importante na literatura e no meio corporativo, juntamente com o crescimento do tema inovação, e principalmente, contribuindo com uma análise pautada de como se dá a relação das variáveis, e por fim, abrindo portas para estudos futuros.

Quanto aos estudos futuros, pesquisadores podem aprofundar-se em variáveis quantitativas que mensurem a relação dos métodos prospectivos com o processo de inovação. Foi identificada uma lacuna de como mensurar quantitativamente a inovação, e logo, como mensurar, baseada em cálculos, a relação dessas variáveis. Partindo desse ponto de mensuração quantitativa, em pesquisas futuras, é interessante analisar diretamente quais métodos prospectivos impactam cada tipo de inovação.

Portanto, em pesquisas futuras, existe campo, para que os pesquisadores aprofundem-se primeiramente, em analisar outras premissas - este estudo propôs os parâmetros de inovação e o nível de intensidade - que possam contribuir para o amadurecimento da análise conjunta das variáveis. E segundo, utilizar de técnicas quantitativas de análise, que desenvolvam a relação do corporate foresight com o processo de inovação. 


\section{REFERÊNCIAS}

Adams, R., Bessant, J., \& Phelps, R. (2006). Innovation management measurement: A review. International Journal of Management Reviews, 8(1), 21-47.

Ahn, J. M., Minshall, T., \& Mortara, L. (2015). Open innovation: a new classification and its impact on firm performance in innovative SMEs. Journal of Innovation Management, 3(2), 3354.

Armstrong, J. S. (1986). The Ombudsman: Research on Forecasting: A Quarter-Century Review, 1960-1984. Interfaces, 16(1), 89-109.

Ashcroft, L. (2004). Developing competencies, critical analysis and personal transferable skills in future information professionals. Library Review, 53(2), 82-88.

Audretsch, D. B. (1995). Innovation, growth and survival. International Journal of Industrial Organization, 13(4), 441-457.

Autio, E. (1998). Evaluation of RTD in regional systems of innovation. European Planning Studies, 6(2), 131-140.

Baron, W., Häußler, S., Luther, W., \& Zweck, A. (2003). Innovations-und Technikanalyse. Chancen und Barrieren betrieblicher Integration. Frankfurt / New York.

Basberg, B. L. (1987). Patents and the measurement of technological change: a survey of the literature. Research policy, 16(2-4), 131-141.

Baum, J. A., Calabrese, T., \& Silverman, B. S. (2000). Don't go it alone: Alliance network composition and startups' performance in Canadian biotechnology. Strategic Management Journal, 267-294.

Becker, P. (2002). Corporate Foresight in Europe: A First Overview, RTK2 Scientific and Technological Foresight, European Commission.

Bell, W. (1997). Foundations of futures studies: history, purposes, and knowledge (Vol. 1). New Brunswick, NJ: Transaction Publishers.

Bezold, C. (2006). Corporate foresight in the US. Presentation at the WFS Conference, Creating Global Strategies for Humanity's Future, Ontario Canada, 28-30 Julho 2006.

Blass, E. (2003). Researching the future: method or madness? Futures, 35(10), 1041-1054.

Borg, O. (2003). The Relationship between futures research and other disciplines and fields of knowledge. In: M. Vapaavuori, S. von Bruun (Eds.), How We Research the Futures [in Finnish]? Acta Futura Fennica No. 5. Helsinki, Vapk-kustannus, ISBN 951-98852-1-8.

Branson, R. (1998). The 7th UK innovation lecture. Innovation in Management. DTI, London.

Burmeister, K., Neef, A., \& Beyers, B. (2004). Corporate foresight. Unternehmen gestalten Zukunft. Hamburg. Murmann Verlag GmbH. 
Burmeister, K., Neef, A., Albert, B., Glockner, H. (2002). Zukunftsforschung und Unternehmen. Praxis, Methoden, Perspektiven. Z_dossier 02, Z_punkt GmbH, Essen.

Chesbrough, H. W. (2003). Open Innovation: The New Imperative for Creating and Profiting from Technology. Harvard Business School Press.

Chesbrough, H. W. (2006). Open innovation: The new imperative for creating and profiting from technology. Harvard Business Press.

Chesbrough, H. W. (2006). Open innovation: The new imperative for creating and profiting from technology. Harvard Business Press.

Chesbrough, H. W. (2010). Business model innovation: opportunities and barriers. Long range planning, 43(2-3), 354-363.

Chesbrough, H., \& Crowther, A. K. (2006). Beyond high tech: early adopters of open innovation in other industries. R\&D Management, 36(3), 229-236.

Christensen, C. M. (1997). The innovator's dilemma: When new technologies cause great firms to fail. Harvard Business School Print.

Cooper, D. R., \& Schindler, P. S. (2016). Métodos de Pesquisa em Administração, 12 ed. São Paulo: McGraw Hill Brasil.

Cooper, R. G., \& Edgett, S. J. (2008). Maximizing productivity in product innovation. ResearchTechnology Management, 51(2), 47-58.

Cuhls, K., Blind, K., \& Grupp, H. (1998). Delphi'98 Umfrage. Zukunft nachgefragt. Studie zur globalen Entwicklung von Wissenschaft und Technik, Karlsruhe.

Cunha, M. P., Palma, P., \& da Costa, N. G. (2006). Fear of foresight: Knowledge and ignorance in organizational foresight. Futures, 38(8), 942-955.

Daheim, C., \& Uerz, G. (2006, September). Corporate foresight in Europe: Ready for the next step? Second International Seville Seminar on Future-Oriented Technology Analysis: Impact of FTA Approaches on Policy and Decision-Making. pp. 1-16.

Daheim, C., Neef, A., Schulz-Montag, B., Steinmüller, K. (2013): Foresight in Unternehmen. Auf dem Weg zur strategischen Kernaufgabe. In: Popp, Reinhold, Zweck, Axel (Hrsg.):

Zukunftsforschung im Praxistest. Zukunft und Forschung Band 3. Wiesbaden, Springer VS (pp. 81-101).

Daim, T. U., Rueda, G., Martin, H., \& Gerdsri, P. (2006). Forecasting emerging technologies: Use of bibliometrics and patent analysis. Technological Forecasting and Social Change, 73(8), 981-1012.

Danguy, J., De Rassenfosse, G., \& van Pottelsberghe de la Potterie, B. (2010). The R\&D-patent relationship: An industry perspective. EIB Papers from European Investment Bank, Economics Department, No $7 / 2009$. 
Dator, J. A. (2007). What futures studies is, and is not. University of Hawaii, Hawaii Research Center for Futures Studies.

Davis, G. (2002, July). Scenarios as a Tool for the 21st Century. In Probing the Future Conference, Strathclyde University, Glasgow, Scotland (pp. 1-7).

DeBresson, C. (1996). Economic Interdependence and Innovative Activity. Cheltenham. Elgar.

Department of Trade and Industry (2002), "SocialDrive", IN. (1989). Technology innovation indicators. R\&D Management, 19(3), 243-249.

Deshpandé, R., Farley, J. U., \& Webster Jr, F. E. (1993). Corporate culture, customer orientation, and innovativeness in Japanese firms: A Quadrad Analysis. The Journal of Marketing, 57(1): 23-37.

Dodgson, M., Gann, D., \& Salter, A. (2006). The role of technology in the shift towards open innovation: the case of Procter \& Gamble. R\&D Management, 36(3), 333-346.

Drew, S. A. (2006). Building technology foresight: using scenarios to embrace innovation. European Journal of Innovation Management, 9(3), 241-257.

Dror, I. (1989). Technology innovation indicators. R\&D Management, 19(3), 243-249.

Dror, I. (1989). Technology innovation indicators. R\&D Management, 19(3), 243-249.

Drucker, P. F. (1985, May). The discipline of innovation. Harvard business review, 63(3), 67-72. EC (1995), "Green paper on innovation”, European Commission, Directorate-General XIII/D.

Estes, G. M., \& Kuespert, D. (1976). Delphi in industrial forecasting. Chemical and Engineering News, 54(35), 40-47.

FARBER, L., \& LARSON, R. (2010). Estatística aplicada, 4 ed. São Paulo: Pearson.

Fidler, D. (2011). Foresight defined as a component of Strategic Management. Futures, 43(5), 540-544.

Fildes, R. (1991). Efficient use of information of subjective forecasts. Journal of Forecasting, 10.

Flechtheim, O. K. (1972) Futurologie. In: Historisches Wörterbuch der Philosophie. Basel. Schwabe \& Co Verlag, 1150-1152.

Flores, B. E., \& White, E. M. (1988). A Framework for the Combination of Forecasts. Journal of the Academy of Marketing Science, 16(3), 95-103.

Freeman, C. (1982). The economics of industrial innovation. UK: Routledge.

Freeman, C., \& Soete, L. (1997). The economics of industrial innovation. Psychology Press. London. Routledge.

Freeman, C., \& Soete, L. (2008). A economia da inovação industrial. Editora da UNICAMP. 
Gassmann, O., Enkel, E., \& Chesbrough, H. (2010). The future of open innovation. R\&D Management, 40(3), 213-221.

Georgoff, D. M., \& Murdick, R. G. (1986). Manager's guide to forecasting. Harvard Business Review.

Gidley, J. M. (2013). Are futures organisations "ahead of their times"? A view of the World Futures Studies Federation in the 21st century. Futures, 45, S16-S31.

Giovinazzo, R. A., \& Wright, J. T. C. (2000). Delphi: uma ferramenta de apoio ao planejamento prospectivo. Caderno de Pesquisas em Administração, 1(12), 54-65.

Godet, M., \& Roubelat, F. (1996). Creating the future: the use and misuse of scenarios. Long range planning, 29(2), 164-171.

Godin, B. (2002). The rise of innovation surveys: Measuring a fuzzy concept. Project on the History and Sociology of S\&T Statistics, Working Paper No. 16. Canadian Science and Innovation Indicators Consortium (CSIIC), Montreal.

Gordon, T. J., Glenn, J. C., \& Jakil, A. (2005). Frontiers of futures research: What's next? Technological forecasting and social change, 72(9), 1064-1069.

Gow, I. D., \& Kells, S. S. (1998). The theory and measurement of profitability. Melbourne Institute of Applied Economic and Social Research.

Green, J. (2004, May). Co-evolving Technology Roadmaps-Roadmaps as living tools. First EUUS Seville Seminar on Future-Oriented Technology Analysis (FTA).

Griliches, Z. (1990). Patent statistics as economic indicators: a survey (No. w3301). National Bureau of Economic Research.

Grinder, O. (1990). Evaluation of the Finnish Powder Metallurgy Technology Program. Helsinki: Technology Development Centre. TEKES.

Gruber, M., \& Venter, C. (2006, November). „Die Kunst, die Zukunft zu erfinden” Theoretische Erkenntnisse und empirische Befunde zum Einsatz des Corporate Foresight in deutschen Großunternehmen. Schmalenbachs Zeitschrift für betriebswirtschaftliche Forschung (Zfbf), 58(7), 958-984.

Grupp, H. (1994). The measurement of technical performance of innovations by technometrics and its impact on established technology indicators. Research Policy, 23(2), 175-193.

Guy, K., Quinta, P. e Hobday, M. (1991). Evaluation of the scientific and tecnological status of FINSOFT: The finnish software technology program. Technology Development Centre TEKES, Helsinki.

Hayward, P. (2005). The worldviews of foresight: from the creature present to integral foresight. The Knowledge Base of Futures Studies, Foresight International, Queensland, Australia. 
Heger, T., \& Rohrbeck, R. (2012). Strategic foresight for collaborative exploration of new business fields. Technological Forecasting and Social Change, 79(5), 819-831.

Heiko, A., Vennemann, C. R., \& Darkow, I. L. (2010). Corporate foresight and innovation management: A portfolio-approach in evaluating organizational development. Futures, 42(4), 380-393.

Hines, A. (2002). A practitioner's view of the future of futures studies. Futures, 34(3), 337-347.

Johannessen, J. A., Olaisen, J. \& Olsen, B. (1999). Managing and organizing innovation in the knowledge economy. European journal of innovation management, 2(3), 116-128.

Johnson, B. B., \& Marcovitch, J. (1994). Uses and applications of technology futures in national development: the Brazilian experience. Technological Forecasting and Social Change, 45(1), 1-30.

Johnson, B., Wright, J., \& Guimarães, P. (1986). Prognósticos tecnológicos como atividade complementar do planejamento: a experiência do CENPES em águas profundas. São Paulo: Fundação Instituto de Administração (FIA).

Kahn, H., \& Wiener, A. J. (1967). The year 2000; a framework for speculation on the next thirty-three years. New York. Macmillan.

Kaivo-oja, J. (2006). Towards integration of innovation systems and foresight research in firms and corporations. The Classical Takeuchi-Nonaka Model Reconsidered and Reformulated. Finland Futures Research Centre. Turku School of Economics. Turku. FFRC-Publications.

Kappel, T. A. (2001). Perspectives on roadmaps: how organizations talk about the future. Journal of Product Innovation Management, 18(1), 39-50.

Kleinknecht, A., Van Montfort, K., \& Brouwer, E. (2002). The non-trivial choice between innovation indicators. Economics of Innovation and new technology, 11(2), 109-121.

Kostoff, R. N., Toothman, D. R., Eberhart, H. J., \& Humenik, J. A. (2001). Text mining using database tomography and bibliometrics: A review. Technological Forecasting and Social Change, 68(3), 223-253.

KOTLER, P., \& KELLER, K. L. (2006). Administração de marketing. Tradução de: Mônica Rosenberg, Brasil Ramos Fernandes e Cláudia Freire.

Kuosa, T. (2011). Evolution of futures studies. Futures, 43(3), 327-336.

Lee, S., \& Park, Y. (2005). Customization of technology roadmaps according to roadmapping purposes: Overall process and detailed modules. Technological Forecasting and Social Change, 72(5), 567-583.

Lee, S., Park, G., Yoon, B., \& Park, J. (2010). Open innovation in SMEs - an intermediated network model. Research policy, 39(2), 290-300. 
Lemola, T., \& Siivonen, T. (1998) Evaluation of the information technology development program (in Finnish). Technology Development Centre. TEKES. Helsinki.

Lundvall, B. A. (1992). National systems of innovation: An analytical framework. London: Pinter.

Makridakis, S., \& Wheelwright, S. C. (1977). Forecasting: issues \& challenges for marketing management. The Journal of Marketing, 24-38.

Marques, N. D. S. (2016). Background do empreendedor e a inovação de produtos em empresas incubadas de base tecnológica (Tese de Doutorado, Universidade de São Paulo).

Martino, J. P. (1993). Technological forecasting for decision making. New York. McGraw-Hill, Inc.

May, G. H. (1996). The future is ours: Foreseeing, managing, and creating the future. Westport, CT. Praeger.

McHale, J. (1978). The emergence of futures research. Handbook of futures research: 5-15.

Mesthene, E. G. (1986). Tecnology and the future. 4. ed., Nova York. St. Martin's Press.

Morettin, P., \& Bussab, W. (2010). Estatística Básica. 6 ed. São Paulo: Editora Saraiva.

Morris, S., DeYong, C., Wu, Z., Salman, S., \& Yemenu, D. (2002). DIVA: a visualization system for exploring document databases for technology forecasting. Computers \& Industrial Engineering, 43(4), 841-862.

Mortensen, P. S., \& Bloch, C. W. (2005). Oslo Manual-Guidelines for collecting and interpreting innovation data. Organization for Economic Cooperation and Development, OECD.

Neely, A., \& Hii, J. (1998). Innovation and business performance: a literature review. The Judge Institute of Management Studies, University of Cambridge, 0-65.

Nelson, R. R. (Ed.). (1993). National innovation systems: a comparative analysis. New York. Oxford University Press.

Nelson, R. R., \& Winter, S. G. (1982). An evolutionary theory of economic change. Cambridge. Harvard University Press.

Norton, M. J. (2001). Introductory Concepts in Information Science. New Jersey. ASIS.

Numminen-Guevara, S. (1992). Review of the evaluation reports of national technology development program (in Finnish). Technical Research Centre of Finland, Group of Technology Studies. Espoo.

Pereira, J.A.G (2014). Estudos dos fatores de promoção estímulo e apoio à criatividade e o desempenho inovador das indústrias da região Sul do Brasil. (Tese de Doutorado, Universidade de São Paulo. 
Peters, T. (1988). Facing up to the need for a management revolution. California Management Review, 30(2), 7-38.

Peterson, G. D., Cumming, G. S., \& Carpenter, S. R. (2003). Scenario planning: a tool for conservation in an uncertain world. Conservation biology, 17(2), 358-366.

Pilkington, A. (2003, July). Technology commercialisation: Patent portfolio alignment and the fuel cell. In: Management of Engineering and Technology, PICMET'03. Technology Management for Reshaping the World. Portland International Conference on (pp. 400-407). IEEE.

Pilkington, A., \& Teichert, T. (2005). Conceptualizing the field of technology management. In Portland International Conference on Management Engineering and Technology (PICMET'05).

Pirttimäki, A. (2006). Foresight in a research and technology organization. Espoo: Helsinki University of Technology [cited 10 April 2012]. Available from Internet: http://www. sal. tkk. fi / publications / pdffiles / tpir06. pdf.

Porter, A. L., Watts, R. J., \& Anderson, T. R. (2003, July). Mining PICMET: 1997-2003 papers help you track management of technology developments. In: Management of Engineering and Technology, 2003. PICMET'03. Technology Management for Reshaping the World. Portland International Conference on (pp. 188-193). IEEE.

Porter, A., Watts, R. (2005). Using the PICMET Abstracts, 1997-2005, In: VantagePoint Reader on your Conference CD: Tutorial. Portland International Conference on Management Engineering and Technology (PICMET'05).

Porter, M. E. (1986). Changing patterns of international competition. California management review, 28(2), 9-40.

Porter, M. E. (1990). The competitive advantage of nations. Harvard business review, 68(2), 73-93.

Porter, M. E. (1991). Towards a dynamic theory of strategy. Strategic management journal, 12(S2), 95-117.

Porter, M. E., \& Ketels, C. H. (2003). UK Competitiveness: moving to the next stage. Paper no. 3. Department of Trade and Industry. London.

Porter, M. E., \& Millar, V. E. (1985). How information gives you competitive advantage. Harvard Business Review, 63(4). 149-160.

Powell, W. W., \& Snellman, K. (2004). The knowledge economy. Annual Review of Sociology, 30, 199-220.

Ratcliffe, J. S. (2006). Challenges for corporate foresight: towards strategic prospective through scenario thinking. Foresight, 8(1), 39-54.

Ringland, G., \& Schwartz, P. P. (1998). Scenario planning: managing for the future. New York: John Wiley \& Sons. 
Ritchey, T. (2006). Problem structuring using computer-aided morphological analysis. Journal of the Operational Research Society, 57(7), 792-801.

Ritchey, T. (2013). Wicked problems: Modelling social messes with morphological analysis. Acta morphologica generalis, 2(1), 1-8.

Rogers, M. (1998). The definition and measurement of innovation. Melbourne Institute Working Paper no 10/98.

Rohrbeck, R. (2012). Exploring value creation from corporate-foresight activities. Futures, 44(5), 440-452.

Rohrbeck, R., \& Gemünden, H. G. (2011). Corporate foresight: Its three roles in enhancing the innovation capacity of a firm. Technological Forecasting and Social Change, 78(2), 231-243.

Rossi, P. H., \& Freeman, H. E. (1993). Evaluation: A Systematic Approach, Newbury Park, CA. Sage Publications. 163-213.

Rothwell, R., \& Gardiner, P. (1985). Invention, innovation, re-innovation and the role of the user: a case study of British hovercraft development. Technovation, 3(3), 167-186.

Roveda, C., \& Vecchiato, R. (2008). Foresight and innovation in the context of industrial clusters: The case of some Italian districts. Technological forecasting and social change, 75(6), 817-833.

Rowe, G., \& Wright, G. (1999). The Delphi technique as a forecasting tool: issues and analysis. International journal of forecasting, 15(4), 353-375.

Ruff, F. (2006). Corporate foresight: integrating the future business environment into innovation and strategy. International Journal of Technology Management, 34(3-4), 278-295.

Sampieri, R. H., Collado, C. H., Lucio, P. B., Murad, F. C., \& Garcia, A. G. Q. (2006). Metodologia de pesquisa. São Paulo: McGraw-Hill.

Sbragia, R., \& Kruglianskas, I. (1998, February). The impact of R\&D on firm innovative performance: a comparative analysis between Brazil and United States. In: 8th International Conference on Management of Technology, IAMOT, Orlando/FL, USA.

Schmookler, J. (1966). Invention and economic growth. Cambridge, MA. Harvard University Press.

Schnaars, S. P. (1989). Megamistakes: Forecasting and the Myth of Rapid Technological Change. New York. London. Free Press; Collier Macmillan.

Schoemaker, P. J. (1995). Scenario planning: a tool for strategic thinking. Sloan Management Review, 36(2), 25-40.

Schulz-Montag, B., \& Müller-Stoffels, M. (2006). Szenarien-Instrumente für Innovations-und Strategieprozesse. IN. F. E. P. Wirlms (Ed.), Szenariotechnik: Vom Umgang mit der Zukunft. pp. 381-297. Bern et al. Haupt Verlag. 
Schumpeter, J. (1934). The Theory of Economic Development. Harvard University Press, Cambridge, Massachusetts.

Schwartz, P. (1991). The art of the long view: scenario planning-protecting your company against an uncertain world. London UK. Century Business.

Seth, S. C. (1986). Futures research: the need for anticipatory management. Futures, 18(3), 366-368.

Skulimowski, A. M. J., \& Pukocz, P. (2012, November). Enhancing creativity of strategic decision processes by technological roadmapping and foresight. In: Lee, V. C. S., Ong, K.-L. (Eds.) KICSS 2012: Seventh International Conference on Knowledge, Information and Creativity Support Systems. Melbourne, Victoria, Australia. IEEE Computer Society. CPS Conference Publishing Services, pp. 223-230.

Skulmoski, G. J., Hartman, F. T., \& Krahn, J. (2007). The Delphi method for graduate research. Journal of Information Technology Education: Research, 6, 1-21.

Slaughter, R. A. (1998). Futures studies as an intellectual and applied discipline. American Behavioral Scientist, 42(3), 372-385.

Smith, K. H. (2005). Measuring innovation. Oxford University Press, Oxford Taylor, William (1994) Control in an age of chaos, Harvard Business Review, pp. 64-70.

Technology Futures Analysis Methods Working Group. (2004). Technology futures analysis: Toward integration of the field and new methods. Technological Forecasting and Social Change, 71(3), 287-303.

Telles, R. (2001). A efetividade da matriz de amarração de Mazzon nas pesquisas em Administração. Revista de Administração da Universidade de São Paulo, 36(4).

Tessun, F. (2005). Innovationstechnik Szenario. Düsseldorf. Symposium Publishing.

Tidd, J., \& Bessant, J. (2015). Gestão da inovação-5. Bookman Editora.

Tinguely, X. (2013). The New Geography of Innovation: Clusters, Competitiveness and Theory. Basingstoke, UK. Palgrave-Macmillan.

Tipping, J. W., Zeffren, E., \& Fusfeld, A. R. (1995). Assessing the value of your technology. Research-Technology Management, 38(5), 22-39.

Trapp, M., Voigt, K. I., \& Brem, A. (2018). Business models for corporate innovation management: Introduction of a business model innovation tool for established firms. International Journal of Innovation Management, 22(01).

Ulrich, W. (1983). Critical Heuristics of Social Planning: A New Approach to Practical Philosophy. Bern, Switzerland. 
Van de Vrande, V., De Jong, J. P., Vanhaverbeke, W., \& De Rochemont, M. (2009). Open innovation in SMEs: Trends, motives and management challenges. Technovation, 29(6-7), 423-437.

Van der Duin, P. A. (2004, May). Linking futures research to innovation processes. A selection of preliminary findings and some possible future directions. In EU-US Seminar: New Technology Foresight, Forecasting \& Assessment Methods, Seville.

Van der Duin, P. A. (2006). Qualitative futures research for innovation. Eburon Academic Publishers, Delft.

Von Reibnitz, U. (1988). Scenario techniques. Hamburg: McGraw-Hill.

Wang, C., \& Kafouros, M. I. (2009). What factors determine innovation performance in emerging economies? Evidence from China. International Business Review, 18, 606-616.

Watts, R. J., \& Porter, A. L. (1997). Innovation forecasting (No. TACOM-17072). Army Tank and Automotive Command, Warren MI.

Wright, G., \& Goodwin, P. (2009). Decision making and planning under low levels of predictability: Enhancing the scenario method. International Journal of Forecasting, 25(4), 813-825.

Wright, J. T. C., \& Spers, R. G. (2006). O país no futuro: aspectos metodológicos e cenários. Estudos Avançados, 20(56), 13-28

Yoshida, N. D. (2011). A prospecção do futuro como suporte à busca de informações para a decisão empresarial: um estudo exploratório (Tese de Doutorado, Universidade de São Paulo).

Yoshida, N. D. (2016). Prospecção do futuro nas empresas: uma proposta de modelo para integração entre o estudo do futuro e a estratégia empresarial (Tese de Doutorado, Universidade de São Paulo).

Yu, D., \& Hang, C. C. (2010). A reflective review of disruptive innovation theory. International Journal of Management Reviews, 12(4), 435-452.

Zins, C. (2006). Redefining information science: from "information science" to "knowledge science". Journal of Documentation, 62(4), 447-461. 


\section{APÊNDICE}

Prezado(a) respondente,

Esta pesquisa é parte do trabalho acadêmico de Mestrado em Administração que apresentarei à Faculdade de Economia, Administração e Contabilidade da Universidade de São Paulo - FEA / USP, sob orientação da Profa. Dra. Renata Spers, Vice-Coordenadora do PROFUTURO.

O trabalho tem como objetivo estudar a prática da prospecção do futuro como uma ferramenta de apoio ao desenvolvimento de inovações nas organizações.

Sua participação é fundamental para o desenvolvimento dessa pesquisa.

As respostas individuais são consideradas como confidenciais e serão somente os resultados agregados. Não serão divulgados nomes dos respondentes, e respectivas empresas.

Estimam-se aproximadamente 10 minutos como tempo para responder o questionário. O resultado consolidado da pesquisa poderá ser enviado ao respondente que desejar recebê-lo.

Caso tenha dúvidas, favor entrar em contato por meio do telefone (11) 99239-1155 ou pelo e-mail priscilamoreti@usp.br.

Muito obrigada pela sua participação.

Atenciosamente,

Priscila Pfaffmann.

Aluna de Mestrado FEA-USP

Profa. Dra. Renata Giovinazzo Spers

PROFUTURO - FEA - USP

\section{INTRODUÇÃO}

Esta pesquisa visa analisar o papel dos métodos prospecção do futuro nas organizações e sua relação com o processo de inovação nas organizações.

Consideramos as seguintes definições:

1- Prospecção do futuro no contexto corporativo: O corporate foresight é considerado como a utilização de técnicas de estudos do futuro com o intuito de analisar a evolução a longo prazo de perspectivas dos ambientes de negócios, mercados e novas tecnologias, além de suas implicações nas estratégias empresarias e inovações. Neste estudo serão consideradas as seguintes técnicas de estudos do futuro, a partir de uma análise do referencial teórico: Técnica Delphi; elaboração de cenários; roadmaps tecnológicos; análises bibliométrica e patentes; análise morfológica; métodos matemáticos; palestras de especialistas; pesquisa de mercado; previsões e projeções de executivos, força de vendas e distribuidores.

2- Inovações nas organizações: Neste trabalho é utilizado o conceito do manual de Oslo, que defini inovação como sendo a "implementação de produtos ou serviços novos ou significativamente melhorados, ou um processo, ou um novo método de marketing, ou um novo método organizacional nas práticas de negócios, na organização do local de trabalho ou nas relações externas (Mortensen \& Bloch: OECD, 2005). Esse conceito escolhido foi referenciado no manual de Oslo, pois esse documento é oficial e válido mundialmente. 


\section{Questionário}

1- Indique na lista abaixo o (s) método (s) de prospecção de futuro utilizado (s) na empresa que você atua no momento. Você pode marcar mais de um método. Em caso de dúvidas nos conceitos dos métodos, consulte o link acima.
a. Método Delphi
b. Elaboração de Cenários
c. Roadmaps Tecnológicos
d. Análises Bibliométrica e Patentes
e. Análise Morfológica
f. Métodos Matemáticos
g. Palestras de Especialistas
h. Pesquisa de Mercado
i. Previsões e projeções de executivos internos, força de vendas e distribuidores.
j. NDA (nenhuma das anteriores = a prospecção não é realizada)
k. Outros:

2- Selecione com um $X$, dentre as opções abaixo, qual a periodicidade de utilização dos métodos indicados na questão anterior, em sua empresa. Se a sua empresa utiliza mais de um método de prospecção marque a periodicidade para cada um deles.

\begin{tabular}{|c|l|l|l|l|l|l|l|l|}
\hline & Trimestral & Semestral & $\begin{array}{c}\text { De 1 em 1 } \\
\text { anos }\end{array}$ & $\begin{array}{c}\text { De 2 em 2 } \\
\text { anos }\end{array}$ & $\begin{array}{c}\text { De 3 em } \\
\text { 3 anos }\end{array}$ & $\begin{array}{c}\text { De 4 em 4 } \\
\text { anos }\end{array}$ & $\begin{array}{c}\text { De 5 em 5 } \\
\text { anos ou mais }\end{array}$ & Não utilizado \\
\hline Delphi & & & & & & & & \\
\hline Cenários & & & & & & & & \\
\hline Roadmaps & & & & & & & & \\
\hline Bibliometria e Patentes & & & & & & & & \\
\hline Análise Morfológica & & & & & & & & \\
\hline Métodos Matemáticos & & & & & & & & \\
\hline Palestras com Especialistas & & & & & & & & \\
\hline $\begin{array}{c}\text { Pesquisa de Mercado } \\
\text { Previsões e projeções de } \\
\text { executivos e força de vendas e } \\
\text { distribuidores }\end{array}$ & & & & & & & & \\
\hline \begin{tabular}{c} 
Outros: \\
\hline
\end{tabular} & & & & & & & & \\
\hline
\end{tabular}

3- Marque na lista abaixo o tipo de inovação que é desenvolvido? (qual a referência da literatura?) em sua atual empresa. Você pode marcar mais de uma opção. Conceitos disponíveis no link.
a. Inovações de produto
b. Inovações de processo
c. Inovações organizacionais
d. Inovações de Marketing
e. Inovações de Modelo de Negócio

4- Marque na lista abaixo como é realizada a inovação em sua atual empresa. Você pode marcar mais de uma opção. Em caso de dúvidas nos conceitos dessas tipologias, consulte o link acima:

a. A inovação realizada internamente, centralizada na matriz da empresa e transferida para as unidades internacionais (caso de multinacionais com matriz fora do Brasil).

b. A inovação é realizada internamente, sendo desenvolvida nas unidades internacionais (Ex.: Unidade Brasil).

c. A inovação é realizada por meio de aquisição de ideias e/ou tecnologias externas que são incorporadas internamente à organização. (Inovação aberta, "de fora para dentro"; 
5- A contribuição e integração entre os métodos de prospecção e a inovação pode acontecer em três níveis de intensidade diferentes. Marque dentre as três opções abaixo qual o nível de intensidade que ocorre na relação entre as técnicas de prospecção e a inovação realizada em sua empresa. Essa nota pode variar em uma escala de 1 a 5, onde 1 é a integração ad hoc (mais fraca), 3 o método de integração (intermediário) e o 5 a integração completa (mais forte). Observação: A sua empresa pode possuir mais de um exemplo de integrações diferentes, assim marque mais de uma opção e justifique.

1

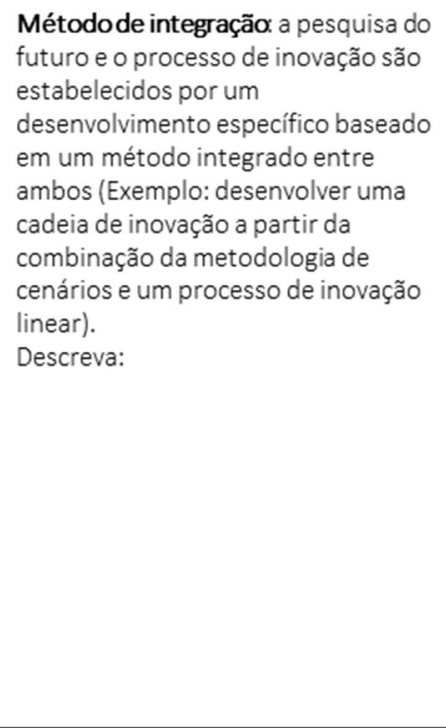

Métodode integração: a pesquisa do futuro e o processo de inovação são prospecção do futuro e o process de inovação são entidades separadas que são combinadas ocasionalmente (Exemplo: Workshop). Descreva:

\section{desenvolvimento específico baseado}

em um método integrado entre

cadeia de inovação a partir da

combinação da metodologia de

cenários e um processo de inovação

linear)

Descreva:

\author{
Integração completa: prospecção do \\ futuro e inovação estão \\ completamente fundidos (Exemplo: \\ Metodologia de Roadmaps que \\ fornece informações sobre o futuro \\ e mostra quais produtos ou serviços \\ serão desenvolvidos no futuro). \\ Descreva:
}

6- $\quad$ Existem 5 parâmetros relacionados ao processo de inovação que as empresas consideram que as técnicas de prospecção podem ser mais úteis e aplicáveis. Indique abaixo como os métodos de prospecção contribuem mais para o processo de inovação. Você pode marcar mais de uma opção. Consulte o link em caso de dúvidas sobre conceitos.

a. Na antecipação da procura futura de alguma ideia inovadora.

b. Aumenta a qualidade do processo de inovação, através das informações importantes coletadas.

c. Orientação ao contexto no qual ele será inserido.

d. Construção de cronograma de implementação factível da inovação estudada.

e. Identificação de inovações estratégicas para o seu negócio.

f. Outros: 
7- Considerando os métodos de prospecção de futuro que a sua empresa utiliza e das quais tenha participado, atribua uma nota entre 1 e 7 para a sua satisfação com as informações obtidas. Considere "satisfação" como sendo "as informações obtidas pelo uso do método atenderam as necessidades para a empresa conseguir inovar / iniciar um processo de inovação". Uma nota 1 significa "totalmente insatisfeito" e uma nota 7 "totalmente satisfeito". Se o método não é utilizado marque a opção "Não utilizado".

\begin{tabular}{|c|c|c|c|c|c|c|c|c|}
\hline & $\begin{array}{c}1= \\
\text { totalmente } \\
\text { insatisfeito }\end{array}$ & $\begin{array}{c}2=\text { muito } \\
\text { insatisfeito }\end{array}$ & $\begin{array}{c}3= \\
\text { insatisfeito }\end{array}$ & $\begin{array}{c}4= \\
\text { indiferente }\end{array}$ & $\begin{array}{c}5= \\
\text { satisfeito }\end{array}$ & $\begin{array}{c}6=\text { muito } \\
\text { satisfeito }\end{array}$ & $\begin{array}{c}7= \\
\text { totalmente } \\
\text { satisfeito }\end{array}$ & $\begin{array}{c}\text { Não } \\
\text { utilizado }\end{array}$ \\
\hline Delphi & & & & & & & & \\
\hline Cenários & & & & & & & & \\
\hline Roadmaps & & & & & & & & \\
\hline Bibliometria e Patentes & & & & & & & & \\
\hline Análise Morfológica & & & & & & & & \\
\hline Métodos Matemáticos & & & & & & & & \\
\hline Palestras com Especialistas & & & & & & & & \\
\hline Pesquisa de Mercado & & & & & & & & \\
\hline $\begin{array}{c}\text { Previsões e projeções de executivos e } \\
\text { força de vendas e distribuidores }\end{array}$ & & & & & & & & \\
\hline
\end{tabular}

Parte 2: Informações sobre (a) respondente da pesquisa e empresa (confidenciais).

1- Qual o seu cargo ou função na empresa?
a. Presidente
b. Diretor
c. Gerente
d. Supervisor
e. Consultor
f. Analista
g. Outro:

2- Qual a sua formação mais recente?
a. Ensino fundamental
b. Ensino médio ou técnico
c. Ensino superior - graduação
d. Ensino superior - pós-graduação lato sensu (Especialização / MBA)
e. Ensino superior - pós-graduação stricto sensu (mestrado, doutorado)
f. Outro: 
3- Qual o seu tempo de experiência profissional (tempo total)?
a. Até 2 anos
b. Entre 2 e 5 anos
c. Entre 6 e 10 anos
d. Entre 11 e 15 anos
e. Entre 16 e 20 anos
f. Mais de 20 anos

4- Qual a forma de controle de sua empresa (no Brasil)?
a. Sociedade de capital aberto
b. Sociedade de capital fechado
c. Limitada
d. Estatal de economia mista
e. Estatal de capital $100 \%$ público
f. Organização do terceiro setor
g. Outro:

5- Qual a predominância da origem do capital de sua empresa?
a. Brasileira.
b. Estrangeira. País de Origem:

6- Qual a quantidade de funcionários de sua empresa (no Brasil)?
a. Menos de 50
b. Entre 51 e 100
c. Entre 101 e 300
d. Entre 301 e 500
e. Entre 501 e 1000
f. Entre 1001 e 2000
g. Acima de 2000

7- Qual o faturamento anual de sua empresa no Brasil?
a. Menos de 10 milhões de reais
b. De 10 até 20 milhões de reais
c. De 21 até 50 milhões de reais
d. De 51 até 100 milhões de reais
e. De 101 até 300 milhões de reais
f. De 301 até 500 milhões de reais
g. De 501 até 1 bilhão de reais
h. De 1 até 1,9 bilhões de reais
i. De 2 até 2,9 bilhões de reais
j. De 3 até 4,9 bilhões de reais
k. De 5 até 6,9 bilhões de reais
I. De 7 até 10 bilhões de reais
m. Acima de 10 bilhões de reais 
8- Qual o setor de atuação de sua empresa?
a. Açúcar e álcool
b. Agricultura
c. Água e saneamento
d. Alimentos
e. Bebidas e fumo
f. Comércio atacadista
g. Comércio varejista
h. Construção e engenharia
i. Eletroeletrônica
j. Energia elétrica
k. Farmacêutica e cosméticos
I. Materiais de construção e decoração
m. Mecânica
n. Metalurgia e siderurgia
o. Mineração
p. Papel e celulose
q. Petróleo e gás
r. Química e petroquímica
s. Serviços especializados
t. Serviços médicos
u. Tecnologia da informação
v. Telecomunicações
w. Têxtil, couro e vestuário
x. Transporte e logística
y. Veículos e peças
z. Outro:

9- Nome de sua empresa (opcional):

10- Seu e-mail para receber os resultados da pesquisa (opcional): 